\title{
Overview of the Second Texas Air Quality Study (TexAQS II) and the Gulf of Mexico Atmospheric Composition and Climate Study (GoMACCS)
}

\author{
D. D. Parrish, ${ }^{1}$ D. T. Allen, ${ }^{2}$ T. S. Bates, ${ }^{3}$ M. Estes,${ }^{4}$ F. C. Fehsenfeld, ${ }^{1}$ G. Feingold, ${ }^{1}$ \\ R. Ferrare, ${ }^{5}$ R. M. Hardesty, ${ }^{1}$ J. F. Meagher, ${ }^{1}$ J. W. Nielsen-Gammon, ${ }^{6}$ R. B. Pierce, ${ }^{7}$ \\ T. B. Ryerson, ${ }^{1}$ J. H. Seinfeld, ${ }^{8}$ and E. J. Williams ${ }^{1}$
}

Received 2 February 2009; revised 9 April 2009; accepted 14 April 2009; published 11 July 2009.

[1] The Second Texas Air Quality Study (TexAQS II) was conducted in eastern Texas during 2005 and 2006. This 2-year study included an intensive field campaign, TexAQS 2006/Gulf of Mexico Atmospheric Composition and Climate Study (GoMACCS), conducted in August-October 2006. The results reported in this special journal section are based on observations collected on four aircraft, one research vessel, networks of groundbased air quality and meteorological (surface and radar wind profiler) sites in eastern Texas, a balloon-borne ozonesonde-radiosonde network (part of Intercontinental Transport Experiment Ozonesonde Network Study (IONS-06)), and satellites. This overview paper provides operational and logistical information for those platforms and sites, summarizes the principal findings and conclusions that have thus far been drawn from the results, and directs readers to appropriate papers for the full analysis. Two of these findings deserve particular emphasis. First, despite decreases in actual emissions of highly reactive volatile organic compounds (HRVOC) and some improvements in inventory estimates since the TexAQS 2000 study, the current Houston area emission inventories still underestimate HRVOC emissions by approximately 1 order of magnitude. Second, the background ozone in eastern Texas, which represents the minimum ozone concentration that is likely achievable through only local controls, can approach or exceed the current National Ambient Air Quality Standard of 75 ppbv for an 8-h average. These findings have broad implications for air quality control strategies in eastern Texas.

Citation: Parrish, D. D., et al. (2009), Overview of the Second Texas Air Quality Study (TexAQS II) and the Gulf of Mexico Atmospheric Composition and Climate Study (GoMACCS), J. Geophys. Res., 114, D00F13, doi:10.1029/2009JD011842.

\section{Introduction}

[2] The Second Texas Air Quality Study (TexAQS II)/ Gulf of Mexico Atmospheric Composition and Climate Study (GoMACCS) is a joint regional air quality and climate change study. The field measurement component of this study was conducted in eastern Texas and over the neighboring Gulf of Mexico beginning in summer 2005 and

\footnotetext{
${ }^{1}$ Chemical Sciences Division, ESRL, National Oceanic and Atmospheric Administration, Boulder, Colorado, USA.

${ }^{2}$ Center for Energy and Environmental Resources, University of Texas at Austin, Austin, Texas, USA.

${ }^{3}$ Pacific Marine Environmental Laboratory, National Oceanic and Atmospheric Administration, Seattle, Washington, USA.

${ }^{4}$ Texas Commission on Environmental Quality, Austin, Texas, USA.

${ }^{5}$ NASA Langley Research Center, Hampton, Virginia, USA.

${ }^{6}$ Department of Atmospheric Sciences, Texas A\&M University, College Station, Texas, USA.

${ }^{7}$ STAR, NESDIS, NOAA, Madison, Wisconsin, USA.

${ }^{8}$ Department of Environmental Science and Engineering and Department of Chemical Engineering, California Institute of Technology, Pasadena, California, USA.

Copyright 2009 by the American Geophysical Union. 0148-0227/09/2009JD011842\$09.00
}

continuing through early autumn 2006. The goal of this program is to provide a better understanding of the sources and atmospheric processes responsible for the formation and distribution of ozone and aerosols in the atmosphere and the influence that these species have on the radiative forcing of climate regionally and globally, as well as their impact on human health and regional haze. The eastern Texas region includes two of the ten largest urban areas in the United States: the Dallas-Fort Worth Metroplex and Greater Houston. TexAQS II includes TexAQS 2006, an intensive study period during summer and early autumn 2006 when the major mobile platforms (four aircraft and one ship) were deployed. GoMACCS is aimed at improving the simulation of the radiative forcing of climate change by lower atmosphere ozone and aerosols. In addition to clear-sky radiative effects, GoMACCS investigates the influence of aerosols on cloud properties and the role of clouds in chemical transformations. The TexAQS 2006 and GoMACCS field deployments were simultaneous and utilized the same mobile platforms.

[3] The roles of ozone and aerosols in air quality and climate change issues are often considered to be separate, 
albeit related, issues. However, the distinction between their roles in these two issues is, at least in part, simply a matter of perspective and scale. Many of the chemical and meteorological processes that affect these two atmospheric species are important to both issues. For example, climate change is usually considered from a global viewpoint where intercontinental transport of ozone and aerosols determines their impact. However, intercontinental transport is either the starting point or the end point of regional air quality concerns, since any particular region contributes outflow to and receives inflow from that transport. This interrelationship of air quality and climate change issues was a foundation of the 2004 International Consortium for Atmospheric Research on Transport and Transformation (ICARTT) study [Fehsenfeld et al., 2006]. The TexAQS/GoMACCS intensive in 2006 continues this approach; the instrumentation and deployment of many of the measurement platforms were planned to simultaneously address the issues involved in both air quality and climate change.

[4] The topics addressed in the present study have a long history. There have been several previous studies conducted in the Texas area. To place the current study into perspective, section 2 provides a brief review of related previous research, most notably the TexAQS 2000 study, which was a direct predecessor of the present field campaign.

[5] The goal of this special journal section is to report many of the TexAQS II/GoMACCS results. The "Final Rapid Science Synthesis Report: Findings from the Second Texas Air Quality Study" (http:/www.tceq.state.tx.us/ assets/public/implementation/air/am/texaqs/rsst_final report.pdf) presented an early summary of some of the important findings that were judged to be particularly important for air quality control policy decisions. This document will be referenced below as RSS Final Report.

[6] The overall TexAQS II/GoMACCS study has several individual component programs that have their own goals and objectives; these separate components are briefly described in section 3. Section 4 describes the meteorological conditions under which the measurements took place, and section 5 highlights some of the particularly important findings. The TexAQS II Radical and Aerosol Measurement Project (TRAMP) is part of TexAQS II/ GoMACCS, but will publish their results in a separate special section in Atmospheric Environment.

\section{Review of Previous Research Related to TexAQS II/GoMACCS}

[7] Much of the previous research on air quality in the eastern Texas region has been supported through contracts with the Texas Commission on Environmental Quality (TCEQ) and the Texas Environmental Research Consortium (TERC). The results of this contract research are often not available in peer-reviewed publications. In such cases reports to the funding agency are referenced here to provide the interested reader access to this work.

\subsection{Observational Studies of Ozone Formation in the Houston Area}

[8] High ozone concentrations in Houston depend strongly upon the interaction of synoptic-scale winds and local coastal/sea breeze oscillations [Banta et al., 2005; Nielsen-
Gammon et al., 2005a]. Light to moderate synoptic-scale winds that oppose the direction of the bay breeze arising in the late morning or early afternoon are particularly conducive to ozone formation and accumulation [Banta et al., 2005; Ngan and Byun, 2008; Darby, 2005]. The stagnant conditions that arise from the interaction of these two forces allow ozone precursors to accumulate and react during the warmest and sunniest portion of the day. Later in the afternoon, the southerly Gulf breeze can advect the pool of high ozone across the city [Darby, 2005; Banta et al., 2005].

[9] High concentrations of light alkenes such as propene, ethene, 1, 3-butadiene and butenes have been observed in the Houston metropolitan area, and are closely associated with petrochemical industry facilities in eastern Harris County, Galveston County, Chambers County, and Brazoria County [Ryerson et al., 2003; Daum et al., 2003, 2004; Berkowitz et al., 2004, 2005; Kleinman et al., 2002, 2003, 2005; Jobson et al., 2004; Karl et al., 2003; Buzcu and Fraser, 2006; Xie and Berkowitz, 2006, 2007; Kim et al., 2005]. These compounds collectively labeled as highly reactive volatile organic compounds (HRVOC), and they play a major role in forming the highest concentrations of ozone observed in the Houston area [Ryerson et al., 2003; Daum et al., 2003, 2004; Kleinman et al., 2002, 2005; Wert et al., 2003; Czader et al., 2008]. Historical analyses of routinely collected VOC data indicate that these compounds are present in high concentrations on a routine basis in the Houston area [Hafner Main et al., 2001; Estes et al., 2002; Brown and Hafner Main, 2002; Brown et al., 2002; Brown and Hafner, 2003; Kim et al., 2005; Buzcu and Fraser, 2006; Xie and Berkowitz, 2006, 2007]. Consequently, the high HRVOC concentrations observed during the two field study periods in 2000 and 2006 are not anomalously large, and the conclusions drawn from those data should be generally applicable to the Houston area.

[10] Field study results from 2000 indicate that industrial emissions of HRVOC have been underreported in Houston [Ryerson et al., 2003; Wert et al., 2003; Xie and Berkowitz, 2007; Karl et al., 2003]. Results from more recent studies indicate that these emissions are still underreported [Robinson et al., 2008; Mellqvist et al., 2007; Smith and Jarvie, 2008]. Source apportionment studies have been performed for VOC observations using TexAQS 2000 data [Karl et al., 2003; Zhao et al., 2004] and routine VOC measurements [Buzcu and Fraser, 2006; Buzcu-Guven and Fraser, 2008; Xie and Berkowitz, 2006, 2007; Wittig and Allen, 2008; Kim et al., 2005; Hafner Main et al., 2001; Brown and Hafner Main, 2002; Brown and Hafner, 2003]. These studies have verified that the observed HRVOC are strongly associated with industrial emissions, and the studies have identified specific areas from which the highest HRVOC emissions are emanating. The research efforts have not yet been able to precisely quantify the actual emissions occurring on a long-term basis from the underreported sources. Mellqvist et al. [2007] and Robinson et al. [2008] have had some success in measuring emission fluxes from industrial point sources, but their efforts have been limited to small areas and short time frames. Both of these flux studies have verified that industrial point source emissions for the areas studied are underreported at least part of the time, by factors approaching or exceeding an order of magnitude. 
[11] Actual emissions from industrial facilities may vary considerably, owing to periodic or sporadic changes in processes, variations in control efficiency, and accidental or planned releases. Mellqvist et al. [2007] found that the ethene emission flux near the Houston Ship Channel varied by a factor of 10 within $30 \mathrm{~min}$, and smaller variations were common from day to day for propene and total alkanes. However, the exact degree of variation of these emissions, and the quantity, composition and locations of sporadic emissions have not been well quantified. They could account for a relatively large portion of the total annual emissions, on the basis of industry-supplied emission reports [Murphy and Allen, 2005; Webster et al., 2007], but since the reported point source inventory is inconsistent with observations, and thus is inadequately quantified, it is difficult to reach a definitive conclusion.

[12] High concentrations of HRVOC are capable of creating high concentrations of ozone. In Houston, ozone forms rapidly and efficiently in plumes of HRVOC and $\mathrm{NO}_{\mathrm{x}}$ coemitted from industrial sources [Daum et al., 2003, 2004; Wert et al., 2003; Ryerson et al., 2003; Kleinman et al., 2002, 2005]. The highest ozone observed in Houston is almost exclusively associated with industrial emission plumes [Daum et al., 2004; Ryerson et al., 2003; Berkowitz et al., 2004].

[13] When the United States moved from a standard based on relatively high maximum 1-h average concentrations (120 ppbv) to ones based on much lower maximum 8-h average concentrations ( $80 \mathrm{ppbv}$ in 1997 and $75 \mathrm{ppbv}$ in 2008) it became clear that the ozone transported into an urban area can contribute significantly toward an exceedance. Nielsen-Gammon et al. [2005b] reported that background ozone concentrations in southeast Texas average about 50 ppbv, with higher concentrations observed with flow from the continental United States, and much lower concentrations observed with flow directly from the Gulf of Mexico.

\subsection{Photochemical Modeling of Ozone Formation in the Houston Area}

[14] Photochemical grid modeling of the Houston area has been challenging owing to the complex coastal wind circulation, the complex petrochemical point emission sources in Harris, Galveston, Chambers, and Brazoria Counties, and the routine challenges associated with modeling a metropolitan area of over five million inhabitants. One of the purposes of the TexAQS 2000 and TexAQS II field studies was to address the uncertainties that affect photochemical grid modeling and its regulatory applications. The insights gleaned from the TexAQS 2000 and subsequent studies have helped resolve some of these uncertainties.

[15] Several studies have endeavored to identify and reduce the uncertainties in the Houston photochemical grid modeling. Foremost among these efforts are the studies that have sought to quantify underreported industrial HRVOC emissions [Ryerson et al., 2003; Wert et al., 2003; Xie and Berkowitz, 2007; Yarwood et al., 2004; Webster et al., 2007; Smith and Jarvie, 2008] and to assess the sensitivities of ozone simulations to the underreporting of these emissions [Byun et al., 2007; Jiang and Fast, 2004; Nam et al., 2006] (see also TCEQ Houston-Galveston-Brazoria online reports: http://www. tceq.state.tx.us/implementation/air/sip/dec2002hgb.html\#docs, http:/www.tceq.state.tx.us/implementation/air/airmod/docs/ hgmor tsd.html, http:/www.tceq.state.tx.us/implementation/ air/sip/dec2004hgb mcr.html, http://www.tceq.state.tx.us/ implementation/air/airmod/data/hgb1.html\#docs, http://www. tceq.state.tx.us/implementation/air/airmod/data/hgb2.html, www.tceq.state.tx.us/assets/public/implementation/air/sip/ hgb/hgb sip 2006/06027SIP proCh2.pdf, and www.tceq. state.tx.us/assets/public/implementation/air/sip/hgb/hgb_sip_ 2006/06027SIP_proCh3.pdf). Other modeling efforts have tested different chemical mechanisms in Houston's photochemical grid modeling, in order to study the effects of using different mechanisms on ozone model performance and control strategy effectiveness [Byun et al., 2005b; Faraji et al., 2008; Czader et al., 2008]. Modeling sensitivity studies have also been performed to guide selection of model parameters such as vertical mixing schemes, number and depth of model layers, and horizontal grid resolution [Kemball-Cook et al., 2005; Byun et al., 2005b, 2007; Bao et al., 2005]. TCEQ has supported photochemical modeling efforts since 2000; additional reports can be found at http:// www.tceq.state.tx.us/implementation/air/airmod/project/ pj_report_pm.html and at http://www.tercairquality.org/ AQQR/Projects/Modeling.

[16] Mesoscale meteorological modeling is used to drive the photochemical grid models, and many studies have been done to examine and reduce the uncertainties in these models as well. One of the most successful efforts sought to improve meteorological simulations of ozone episodes using radar profiler and other upper level wind data to nudge met modeling [Nielsen-Gammon et al., 2007; Zhang et al., 2007; Stuart et al., 2007; Bao et al., 2005; Fast et al., 2006]. Other efforts improved land cover data and land surface modeling [Byun et al., 2005a; Cheng and Byun, 2008; Cheng et al., 2008], and studied the sensitivity of ozone simulations to solar irradiance and photolysis rates [Zamora et al., 2005; Fast et al., 2006; Pour-Biazar et al., 2007; Byun et al., 2007; Koo et al., 2008]. TCEQ has supported mesoscale meteorological modeling efforts by Nielsen-Gammon and others since 2001; 25 reports about mesoscale meteorological modeling in Houston have been provided to TCEQ, and can be found at http://www.tceq. state.tx.us/implementation/air/airmod/project/pj_report_ met.html\#met02.

\section{Components of TexAQS II/GoMACCS}

[17] Sections 3.1-3.6 describe the principal goals and resources contributed by the independent programs that constituted the larger, 2-year TexAQS II/GoMACCS field program. Appendices $\mathrm{A}$ and $\mathrm{B}$ give more experimental details of the individual platforms and sites. In addition to the research that is described in this special section, the program also included work conducted by other groups. The Air Quality Research program of TERC funded much of this additional work, including the TexAQS II Radical Measurement Project (TRAMP), the Northeast Texas Plume Study (NETPS), the TexAQS II Tetroon Campaign, research flights of the Baylor University Piper Aztec aircraft and the Houston Triangle Experiment. More information can 
be found at the TERC website: http://www.tercairquality. org/AQR/.

\subsection{TexAQS 2006 and Gulf of Mexico Atmospheric Composition and Climate Study (NOAA)}

[18] The NOAA WP-3D and Twin Otter Lidar aircraft combined with the Research Vessel Ronald H. Brown and the radar wind profiler network to conduct the combined TexAQS 2006/GoMACCS study. The WP-3D mapped trace gases, aerosols and radiative properties over the eastern Texas region and the Lidar aircraft, mapped the regional distribution of boundary layer ozone, aerosols and mixing layer heights in the same region. The Ronald H. Brown used both in situ and remote atmospheric sensors to examine low-altitude outflow of pollution from eastern Texas and the chemical environment of the Texas Gulf Coast region. The Radar Wind Profiler Network included ten sites that measured vertical profiles of boundary layer winds (see Appendix B), which provided information on regional-scale trajectories and transport of air masses. The science plan that describes the research aims of Texas 2006/GoMACCS can be found at http://esrl.noaa.gov/csd/2006/.

\subsection{Ground Site Network (TCEQ, University of Texas, and Texas A\&M University)}

[19] TCEQ maintains a network of almost 100 ground stations in eastern Texas that measure and archive concentrations of air pollutants and meteorological data (data are available at the TCEQ web monitoring operations web site: http://www.tceq.state.tx.us/compliance/monitoring/air/ monops/hourly_data.html). These sites are operated to assess compliance with National Ambient Air Quality Standards, and consequently the measurements are primarily focused on concentrations of ozone, particulate matter, and their precursors. They are located almost exclusively in urban areas where the potential for human exposures to these air pollutants is greatest. For TexAQS II, additional sites were deployed to provide a combination of upper air meteorological information and surface concentrations of air pollutants in rural areas. More details of these specially deployed sites are given in the descriptions of the Radar Wind Profiler Network and the Surface Air Quality Monitoring Network in Appendix B. The goal of these additional sites was to characterize boundary layer meteorology and surface air quality for the assessment of regional air pollutant transport. Finally, Texas A\&M University operated a flux tower with measurements of key constituents in Lick Creek Park, just south of College Station, Texas.

\subsection{TexAQS 2006/GoMACCS Aerosol-Cloud Study (National Science Foundation and NOAA)}

[20] The CIRPAS Twin Otter aircraft was the primary platform for the aerosol-cloud study. The major scientific objectives centered on the relationship between aerosol physical and chemical properties and the microphysical and radiative properties of the clouds. Therefore, this experiment represents a continuing effort to obtain detailed, in situ field data that will aid in understanding the indirect climatic effect of aerosols. In addition, there was focus on understanding the atmospheric evolution of aerosols. Specific scientific questions included: (1) To what extent can a CCN closure be accomplished; that is, how closely can in situ measured CCN behavior of the ambient aerosol be replicated on the basis of measured aerosol size distribution and composition? This question is of special interest in a heavily polluted urban area like Houston. (2) To what extent can theoretical aerosol-cloud activation models predict cloud droplet number concentrations, given measurements of aerosol size and composition? (3) To what extent do measured radiative fluxes above and below cloud agree with those predicted on the basis of atmospheric radiative transfer models? (4) To what extent can evidence of aerosol effects on cloud microphysics, precipitation initiation and cloud radiative properties be observed? (5) How does entrainment influence cloud microphysics? (6) To what extent can large eddy simulation (LES) of cloud fields predict the statistical properties of those measured? (7) Can the sources and character of the organic portion of the Houston aerosol be understood? (8) What processes govern the evolution of aerosols as they are advected from source-rich areas?

\subsection{Satellite Data Integration (NASA, NOAA, and TCEQ)}

[21] Scientists from a number of NASA and NOAA satellite groups participated in the TexAQS/GoMACCS field mission. The satellite component contributed to flight planning activities and integrated measurement and modeling studies focusing on influences of continental-scale processes on regional air quality within east Texas. Airborne and surface measurements were used to verify chemical and aerosol analyses and to validate satellite observations on local scales. Ensemble trajectories (sampling analyzed chemical and aerosol fields to account for chemical transformation during transport) were used to identify source regions of pollution sampled by the airborne and surface sensors. Satellite measurements were used to constrain the chemical and aerosol analyses, quantify source strengths and verify model predictions on a regional to global scale.

[22] Satellite instruments are currently able to observe several criteria pollutants in the troposphere including ozone $\left(\mathrm{O}_{3}\right)$, nitrogen dioxide $\left(\mathrm{NO}_{2}\right)$, carbon monoxide $(\mathrm{CO})$, sulfur dioxide $\left(\mathrm{SO}_{2}\right)$ and aerosol optical depth (AOD) (Table A8 in Appendix A). Satellites also provide retrievals of atmospheric thermodynamic properties (temperature, moisture, and clouds) as well as surface and top of atmosphere (TOA) radiative fluxes. Polar-orbiting satellites (e.g., Terra, Aqua, Aura, and the National Polar-Orbiting Operational Environmental Satellite, or POES) provide global coverage once per day and offer a unique vantage point for observing intercontinental pollution transport. Geostationary satellites (e.g., Geostationary Operational Environmental Satellite, or GOES) provide coverage over the continental United States once every fifteen minutes and are useful for following continental-scale pollution transport and regional pollution events. Satellite tropospheric trace gas and aerosol retrievals and area-burned estimates provide valuable information for emission modeling. Long-term, space-based observations place airborne measurements obtained during limited duration field experiments within the context of observed interannual variability and trends.

[23] The availability of near-real-time (within 12-24 h) satellite data significantly increased the role of satellite data in flight planning during TexAQS/GoMACCS. High 
temporal resolution Step and Stare profile retrievals of tropospheric $\mathrm{O}_{3}$ and $\mathrm{CO}$ profiles from the Tropospheric Emission Spectrometer (TES) [Beer, 2006] were available for studying boundary layer exchange processes. $500 \mathrm{mb} C O$ retrievals from the Atmospheric Infrared Sounder (AIRS) [McMillan et al., 2005] provided a regional context for interpretation of ground and airborne measurements. The Multiangle Imaging SpectroRadiometer (MISR) [Diner et al., 1998] provided retrievals of AOD and aerosol type. Aerosol attenuated backscatter measurements from the Cloud Aerosol Lidar with Orthogonal Polarization (CALIOP) instrument onboard the Cloud-Aerosol Lidar and Infrared Pathfinder Satellite Observation (CALIPSO) satellite [Winker et al., 2007] were used to identify the altitude and thickness of regional- and continental-scale aerosol plumes. GOES Aerosol/Smoke Product (GASP) AOD [Knapp et al., 2002] and GOES visible imagery [Gurka et al., 2001] characterized transport of aerosol and smoke plumes. GOES Wildfire Automated Biomass Burning Algorithm (WF-ABBA) [Prins et al., 1998] and MODIS [Giglio et al., 2003] fire detections were used to identify biomass burning sources and provide area-burned estimates for wild fire emissions modeling.

[24] The availability of real-time (within $0-3 \mathrm{~h}$ ) satellite trace gas and aerosol retrievals allowed chemical and aerosol assimilation/forecast systems to be used for flight planning activities during TexAQS/GoMACCS. Total column ozone retrievals from the Ozone Monitoring Instrument (OMI) [Levelt et al., 2006a, 2006b] and AOD retrievals from the Moderate Resolution Imaging Spectroradiometer (MODIS) instruments [Kaufman et al., 1997] provided for real-time chemical and aerosol data assimilation/forecasting activities. The use of satellite, aircraft, and surface measurements, in conjunction with advanced modeling techniques, supports the development of an Air Quality Assessment and Forecasting capabilities under the U.S. Integrated Earth Observation System (http://usgeo.gov/ docs/EOCStrategic_Plan.pdf).

\subsection{Airborne High Spectral Resolution Lidar Aerosol Investigations (NASA)}

[25] During TexAQS/GoMACCS, the NASA Langley Research Center (LaRC) airborne High Spectral Resolution Lidar (HSRL) was deployed on the NASA B200 King Air aircraft to measure profiles of aerosol extinction, backscattering, and depolarization. These measurements were acquired to address several objectives:

[26] 1. Map the vertical and horizontal distributions of aerosols during transport downwind from major sources. The HSRL profiles provided "curtains" showing the aerosol distributions below the aircraft. Since the lidar measurements clearly depict the altitudes of aerosol layers, they were used to indicate the height to which aerosols are injected into the atmosphere, which is important for modeling the long-range transport of aerosols.

[27] 2. Evaluate measurements from the CALIOP sensor on the CALIPSO satellite. HSRL backscatter, extinction, and depolarization profiles were used to evaluate the CALIOP calibration, as well as the level 1 (attenuated backscatter), and level 2 (aerosol backscatter, aerosol extinction) profiles.

[28] 3. Provide profiles of aerosol extinction, backscatter and depolarization and investigate the use of these profiles to identify aerosol type. The aerosol intensive parameters measured by the HSRL (extinction/backscatter ratio, backscatter wavelength dependence, depolarization) provided a means to identify various aerosol types and investigate the vertical and horizontal variability of aerosol types in the TexAQS/GoMACCS study region, and to determine how aerosol optical thickness was distributed among the various aerosol types.

[29] 4. Characterize the behavior and variability of the planetary boundary layer (PBL) height. Lidar systems have been widely used to examine the structure and variability of the PBL top and to derive the entrainment zone depth [e.g., Cohn and Angevine, 2000; Brooks, 2003]. Since the King Air flew at high $(\sim 9 \mathrm{~km})$ altitude exclusively, the lidar measurements featured long, uninterrupted observations of the PBL and entrainment zone.

[30] 5. Assess model simulations of aerosol extinction profiles. The vertical profiles of aerosol extinction and aerosol intensive parameters measured by the HSRL were used to help evaluate the ability of models to reproduce aerosol extinction profiles and optical thickness.

\subsection{IONS-06-NASA}

[31] In support of TexAQS II, IONS-06 operated 22 sounding stations (Table A9 in Appendix A) to provide consistently located vertical profiles of ozone concentration over Houston and beyond [Thompson et al., 2008]. IONS-06 was strategically configured to align a group of sites along important transport pathways, i.e., Pacific to western U.S. coast, southwest United States and Mexico toward Houston, Gulf coast and Caribbean toward Houston, and Houston toward Huntsville, Alabama-northeastern North America [Cooper et al., 2007]. At Houston, there were two IONS-06 sampling venues during TexAQS 2006. Launches by G. A. Morris et al. (An evaluation of the influence of the morning residual layer on afternoon ozone concentrations in Houston using ozonesonde data, submitted to Atmospheric Environment, 2009) were performed at the University of Houston $\left(29.7^{\circ} \mathrm{N}, 95.4^{\circ} \mathrm{W}\right)$ not far from downtown Houston, 17 August to 5 October 2006. Sondes were also launched from the R/V Ronald H. Brown during August along its cruise track; this series continued through 11 September 2006 [Thompson et al., 2008].

\section{Meteorological Context of TexAQS II/ GoMACCS}

[32] The entire period of TexAQS II (1 June 2005 to 18 October 2006) was unusually dry for the state of Texas as a whole. Drought was widespread November 2005 until January 2007. However, Southeast Texas and the coastal portions of Texas was one of the few areas spared the unusual drought conditions. Figure 1 shows drought conditions across Texas at the beginning and end of TexAQS $2006 /$ GoMACCS intensive field activities of 2006. The drought reached its peak during late August and early September 2006, after which rains helped mitigate conditions. While Houston avoided drought conditions, the Dallas-Fort Worth area was remarkably dry. In August 2006, Bush Intercontinental Airport in Houston (IAH) was $0.6^{\circ} \mathrm{C}$ above normal, with $89 \%$ of normal rainfall, while Dallas-Fort 

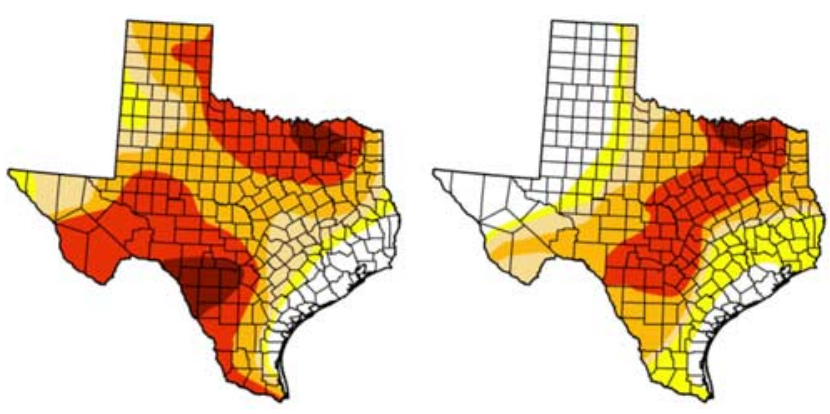

Figure 1. Drought conditions in Texas on (left) 1 August 2006 and (right) 10 October 2006, as depicted by the U.S. Drought Monitor. The range of colors from white to dark red correspond to no drought, incipient drought, moderate drought, severe drought, extreme drought, and exceptional drought.

Worth International Airport (DFW) was $3.0^{\circ} \mathrm{C}$ above normal, with only $26 \%$ of normal rainfall. September was a more typical month: IAH saw temperatures $0.5^{\circ} \mathrm{C}$ above normal with $74 \%$ of normal rainfall, while DFW saw temperatures $0.1^{\circ} \mathrm{C}$ above normal with $107 \%$ of normal rainfall.

[33] Meteorological differences yield differences in air pollution characteristics between TexAQS 2000 and TexAQS II. TexAQS 2000 took place during a period of substantial drought in southeast Texas, and the very end of August and the first few days of September were characterized by unusually high temperatures that culminated in numerous records being broken. By comparison, the TexAQS II/ GoMACCS period was close to normal in the Houston area with respect to both temperature and precipitation.

[34] Typically during August and September, the strong southerly winds of midsummer begin to weaken and cold fronts penetrate southward farther and farther into Texas. Behind the cold fronts, northeast winds tend to bring polluted air from the central and eastern United States. The extent of transport from the northeast controls background ozone levels, while enhancement of ozone due to local emissions depends on the lightness of the winds [Nielsen-Gammon et al., 2005a, 2005b]. Mean winds do not tell the whole story; often just a few days can make an ozone season exceptionally bad.

[35] To help characterize the wind conditions during TexAQS 2006/GoMACCS, Figure 2 shows the mean wind conditions for each day during the field intensive, 1 August 2006 through 15 October 2006. Winds are represented as daily mean winds from buoy 42035 , located just offshore from Galveston. Each day's wind is represented by its mean westerly $(u)$ and southerly $(v)$ values, so that a vector drawn from the origin to a given symbol depicts the wind speed and direction for that symbol. The winds during the field intensives of TexAQS 2000 and 2006 are compared with all winds from 1998 through 2006, 1 August through 15 October (blue diamonds) and days with an 8-h maximum ozone greater than $85 \mathrm{ppbv}$ are identified.

[36] The distribution of winds during the 2006 field intensive broadly matches the climatology, except for a

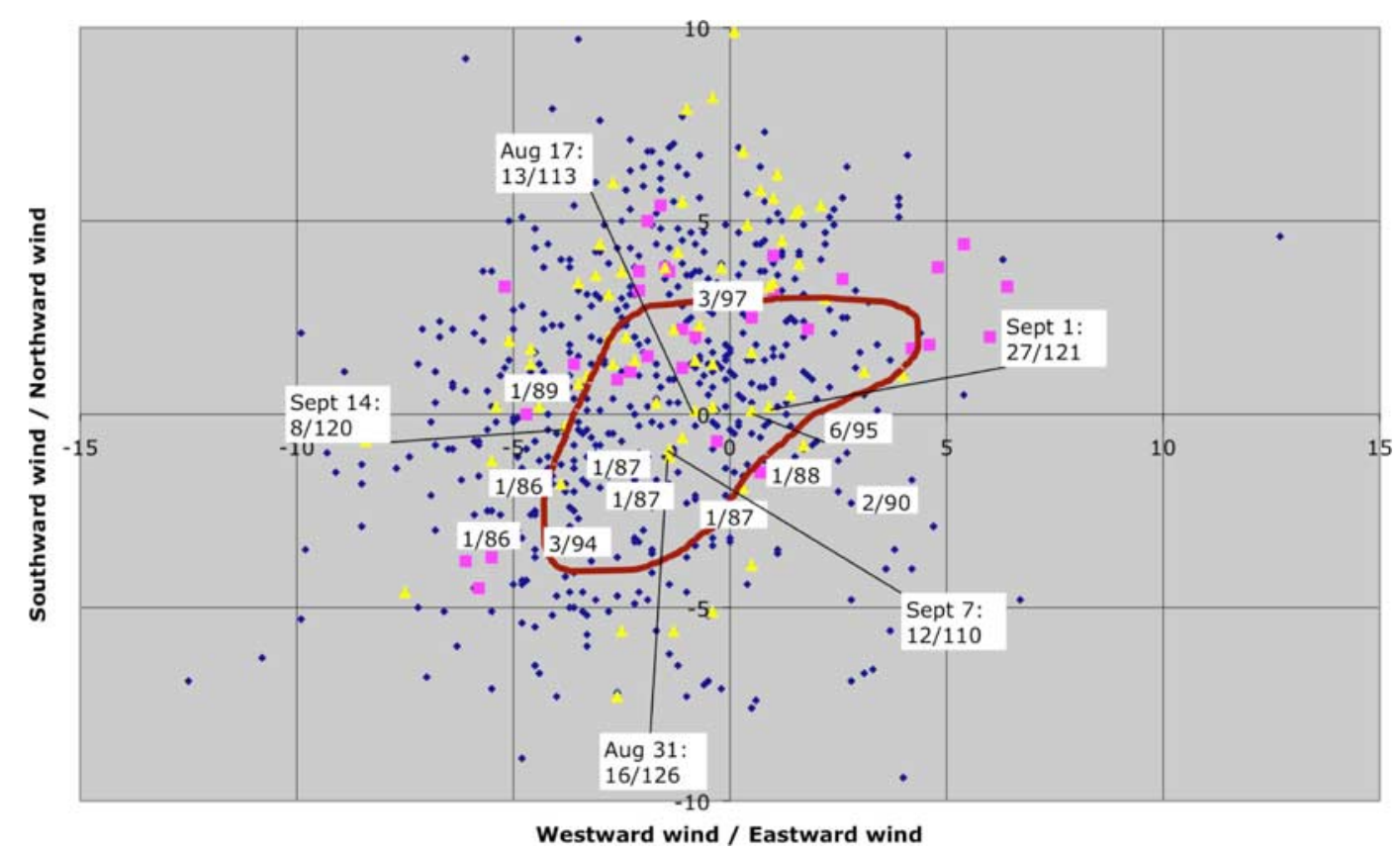

Figure 2. Wind conditions during 1 August through 15 October 1998-2006. Each dot represents the 24-h mean wind measured at Buoy 42035, just offshore of Galveston. The westerly $(u)$ and northerly $(v)$ wind components are given along the $x$ and $y$ axes, respectively; a dot in the northeast quadrant, for example, corresponds to a wind blowing from southwest to northeast. Pink squares are winds during TexAQS 2000. Yellow triangles are winds during TexAQS 2006/GoMACCS. Text insets give number of stations in 2006 exceeding an 8-h ozone average of $85 \mathrm{ppb}$ and the maximum value of 8-h ozone average (ppbv). Dates are given for exceedances of over $100 \mathrm{ppbv}$. The maroon curve indicates the approximate area of winds conducive to high ozone during 1998-2004. 
surplus of strong winds from the south (yellow triangles near the top center of Figure 2) and a deficit of strong winds from the east (lack of yellow triangles near the left of Figure 2). The situation less closely resembles that of TexAQS 2000. TexAQS 2006 did not experience any analogs to the strong westerly flow of 30 August 30 to 1 September 2000 (rightmost pink squares), and conversely, TexAQS 2000 experienced almost no light winds from the northeast even though they were common during TexAQS 2006 and in general.

[37] The maroon line in Figure 2 depicts the margins of wind conditions that were favorable for high ozone during TexAQS 2000. Within this line, the only conditions that occurred in both 2000 and 2006 are light winds from the southeast. In 2000, one such day, 25 August, produced very high ozone concentrations. Yet, in 2006, few such days resulted in high ozone. A check of individual days (not shown) indicates that most of these days involved widespread rain or cloudiness in 2006, suppressing what would otherwise be favorable ozone formation conditions.

[38] The highest levels of ozone within the Houston area during TexAQS 2006 occurred on four Thursdays (17 August, 31 August, 7 September, and 14 September) and one Friday (1 September). As suggested by the mean wind on 1 September being almost directly opposite the mean wind on 31 August, there is some evidence that pollutants from 31 August may have recirculated back into parts of Houston on 1 September. The mean wind on 17 August was also sufficiently close to zero that some recirculation may have been possible under the influence of the sea breeze. In general, though, the highozone events during 2006 were less directly influenced by the sea breeze than those of 2000.

[39] Although no high-ozone days occurred in both 2000 and 2006 under similar meteorological circumstances, the combined records from 2000 and 2006 together encompass all common wind scenarios for high ozone in the Houston area.

\section{Overview of Results}

[40] This section presents an overview of the some of the important results of the TexAQS II/GoMACCS field study, including those published in this special journal section, published elsewhere, and emerging in manuscripts that are still in preparation. Some additional results are described that are presently not included in any planned publications, but are discussed here to give a complete overview of the observational programs involved in TexAQS II/GoMACCS.

\subsection{Observational Tests of Emission Inventories}

[41] Air quality and climate change problems originate from society's increased emissions of air pollutants and their precursors (VOC, $\mathrm{NO}_{\mathrm{x}}, \mathrm{SO}_{2}, \mathrm{CO}$, air toxics) and radiative forcing agents $\left(\mathrm{CO}_{2}, \mathrm{CH}_{4}, \mathrm{~N}_{2} \mathrm{O}\right.$, halocarbons, black carbon, aerosols). Our understanding of these emissions on both regional and global scales is critically limited. The data collected during this field study provide tests of emission inventories, some of which are summarized here.

5.1.1. Emissions of VOC From Petrochemical Facilities in the Houston Area

[42] Two independent techniques were deployed during TexAQS 2006 to quantify fluxes of ethene from industrial sources near Houston, Texas: a laser photoacoustic spectroscopy (LPAS) instrument on board the WP-3D aircraft [de Gouw et al., 2009] and a solar occultation flux (SOF) instrument operated in a mobile laboratory (J. Mellqvist et al., Measurements of industrial emissions of alkenes in Texas using the Solar Occultation Flux method, submitted to Journal of Geophysical Research, 2009). The latter instrument also measured propene and total alkane fluxes. Both instruments repeatedly quantified ethene fluxes from the Mont Belvieu chemical complex to the northeast of Houston, one of the largest emission sources in the Houston area. The results from the LPAS $\left(520 \pm 140 \mathrm{~kg} \mathrm{~h}^{-1}\right)$ during 10 different WP-3D flights agreed well with those from 6 independent measurements by the SOF $\left(440 \pm 130 \mathrm{~kg} \mathrm{~h}^{-1}\right)$. Two considerations can serve to put these fluxes in perspective. First, the 2006 TCEQ point source database estimated the total ethene emissions from Mont Belvieu to be $81 \mathrm{~kg} \mathrm{~h}^{-1}$, a factor of 5 to 7 lower than the measured fluxes. Similar discrepancies are generally found throughout the industrial facilities in the Houston area; Mellqvist et al. (submitted manuscript, 2009) found that for all measurements during the campaign, the 2006 emission inventory underestimated the measured fluxes by an average factor of 10 for ethene and 11 for propene. Second, Murphy and Allen [2005] investigated the role of large, accidental releases of HRVOC in ozone formation in the HGB area, and identified 763 HRVOC emission events in a 1-year period. More than half of these events released less than $454 \mathrm{~kg}$ total HRVOC. Thus, the Mont Belvieu complex routinely emits more ethene each hour than the total HRVOC released in the majority of the individual accidental release events considered by Murphy and Allen [2005]. The emissions from these facilities represent a much larger source of HRVOC and much more substantial contribution to ozone formation than indicated by current emission inventories.

[43] Results from four different observationally based analyses (ethene/ $\mathrm{NO}_{\mathrm{x}}$ emission ratios in plumes from petrochemical facilities, the ambient distribution of ethene concentrations, the ambient distribution of formaldehyde, and long-term auto-GC ethene measurements) all show evidence for a significant decrease in ethene emissions in the Greater Houston area between the TexAQS 2000 and TexAQS II studies [Gilman et al., 2009] (see also RSS Final Report). The weight of evidence from these four analyses indicates that ethene emissions from the petrochemical facilities decreased by about $40( \pm 20) \%$ (i.e., approximately a factor of 1.7) between 2000 and 2006.

[44] A remarkable finding of the TexAQS II study is that the underestimate of emission fluxes of HRVOC from petrochemical facilities established by the TexAQS 2000 study has not yet been fully integrated into inventories developed since that study. The TexAQS 2000 study established that inventories underestimated these emissions by 1-2 orders of magnitude [Ryerson et al., 2003]. In an analysis prepared for the RSS Final Report, John Jolly of TCEQ reported that total HRVOC emissions included in the Harris County Point Source emission inventory for 20002004 were fairly steady across those years, with the lowest year (2002, at 3300 tons) being about 83 percent of the highest year (2004, 4000 tons). Mellqvist et al. (submitted manuscript, 2009) show that there have been some recent, 


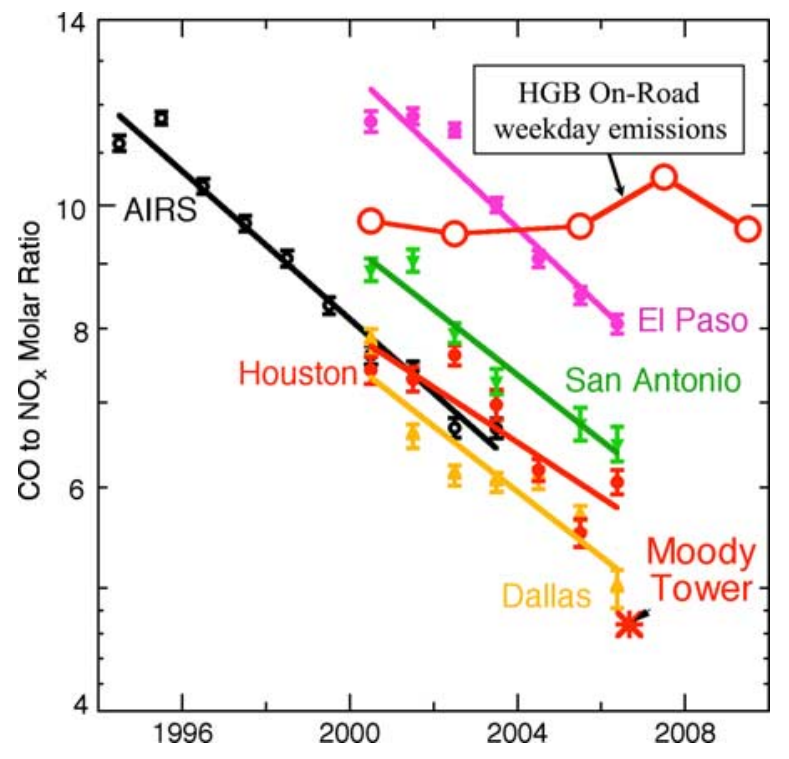

Figure 3. Measured $\mathrm{CO}$ to $\mathrm{NO}_{\mathrm{x}}$ ratios (solid symbols color-coded according to area) in four Texas urban areas during the morning traffic peak (0600 to 0900 local standard time) compared to the ratio from on-road mobile emissions from the HGB emission inventory (open symbols). The black symbols give the average ratio for all stations in the EPA AIRS network from Parrish [2006].

relatively small systematic increases in the inventoried HRVOC emissions; the last eight entries in their Table 3 indicate that inventoried ethene and propene emissions from a large majority of the petrochemical facilities in the Houston area increased from 149 and $176 \mathrm{~kg} \mathrm{~h}^{-1}$, respectively, in 2004 to 277 and $252 \mathrm{~kg} \mathrm{~h}^{-1}$, respectively, in 2006 . Thus, decreases in actual HRVOC emissions and some increases in inventory estimates have improved the accuracy of the emission estimates, but importantly, inventories still underestimate HRVOC emissions by $\sim 1$ order of magnitude.

[45] A chemically diverse set of volatile organic compounds (VOCs) and other gas-phase species was measured in situ aboard the NOAA R/V Ronald H. Brown as the ship sailed throughout the Houston and Galveston Bay area (HGB) [Gilman et al., 2009]. The reactivities of $\mathrm{CH}_{4}$, $\mathrm{CO}$, VOCs and $\mathrm{NO}_{2}$ with the hydroxyl radical, $\mathrm{OH}$, were determined in order to quantify the contributions of these compounds to potential ozone formation. The total $\mathrm{OH}$ reactivity was high in $\mathrm{HGB}$, averaging $10 \mathrm{~s}^{-1}$, primarily owing to the impact of industrial emissions. In comparison, during ship-based measurements downwind from New York City and Boston in 2002, the total $\mathrm{OH}$ reactivity only very rarely exceeded $10 \mathrm{~s}^{-1}$ [Goldan et al., 2004]. By compensating for the effects of boundary layer mixing, the diurnal profiles of the $\mathrm{OH}$ reactivity were used to determine the source signatures and relative magnitudes of biogenic, anthropogenic (urban + industrial), and oxygenated VOCs as a function of the time of day. This analysis demonstrates that the predominant source of formaldehyde to the air masses sampled by the Ronald H. Brown in HGB was from secondary production, with primary emissions playing only a minor role. The secondary formation of oxygenated VOCs in addition to the continued emissions of anthropogenic
VOCs served to sustain elevated levels of $\mathrm{OH}$ reactivity throughout the time of peak ozone production.

\subsubsection{On-Road Mobile Emission Inventories in the Houston Area}

[46] Figure 3 compares $\mathrm{CO}$ to $\mathrm{NO}_{\mathrm{x}}$ ratios from ambient measurements collected during the morning rush hour travel peak with those from emission inventories. The data are treated as described by Parrish [2006]. The Dallas and Houston routine ambient data are in excellent agreement with the nationwide AIRS data. The TexAQS 2006 ratio derived from the TRAMP measurements made at the Moody Tower site (B. Lefer, private communication, 2007) agree reasonably well with the routine monitoring data. The ratios in El Paso and San Antonio are significantly higher, which is attributed to the older vehicle fleets found in those urban areas.

[47] In Figure 3 the Houston area (indicated as HGB) inventory overestimates the $\mathrm{CO}$ to $\mathrm{NO}_{\mathrm{x}}$ emission ratio, and that overestimate becomes worse with time as the inventory does not show a significant temporal decrease. It should be noted that the on-road emissions inventory value for 2000 was calculated with actual data for 2000, whereas the on-road mobile inventories for later years are less certain projections. Parrish [2006] showed that nation-wide the rapid decrease $(6.6 \% / \mathrm{a})$ in the $\mathrm{CO}$ to $\mathrm{NO}_{\mathrm{x}}$ ratio is partially due to a slower decrease in $\mathrm{CO}$ emissions $(4.6 \% / \mathrm{a})$, which implies a significant increase in $\mathrm{NO}_{\mathrm{x}}$ emissions (approximately $2 \% / \mathrm{a}$ ). The large inventory overestimate in the ratio in 2006 is attributed to a factor of 2 overestimate in $\mathrm{CO}$ emissions, and an underestimate in present $\mathrm{NO}_{\mathrm{x}}$ emissions. This causes $\mathrm{NO}_{\mathrm{x}}$ to $\mathrm{CO}$ emission ratios in urban areas, which are often dominated by on-road mobile emissions, to be underestimated by current emission inventories.

[48] Urban emission ratios sampled by the WP-3D aircraft in 2006 and the NCAR Electra aircraft in 2000 are consistent with measurements carried out at a Houston highway tunnel in 2000 [McGaughey et al., 2004]. These measurements demonstrate the weekday increase in $\mathrm{CO} /$ $\mathrm{CO}_{2}$ and $\mathrm{CO} / \mathrm{NO}_{\mathrm{x}}$ emission ratios from midday to the afternoon rush hour correlated with increases in the proportion of gasoline vehicles during rush hour. Similar to the routine monitors, the aircraft and tunnel observations indicate that inventories overestimate mobile source $\mathrm{CO}$ by at least a factor of 2. Comparison of the 2000 and 2006 aircraft data suggests that urban $\mathrm{CO}$ emissions declined by roughly a factor of 2 between the studies (using either $\mathrm{CO}_{2}$ or $\mathrm{NO}_{\mathrm{x}}$ as a comparison) in agreement with the National Emission Inventories from 1999 and 2005, which show a similar decline (G. J. Frost et al., manuscript in preparation, 2009).

\subsubsection{Marine Vessel Emissions in the Texas Gulf Coast Region}

[49] Gaseous and particulate emissions from commercial marine shipping were investigated through measurements made in more than 200 exhaust plumes from a variety of ships encountered by the Ronald H. Brown throughout the Gulf Coast region of Texas including most of the major ports and the Houston Ship Channel. Gas-phase and particulate emission factors were determined under actual operating conditions and compared with published emission factors used for emission inventory modeling.

[50] E. J. Williams et al. (Emissions of $\mathrm{NO}_{\mathrm{x}}, \mathrm{SO}_{2}, \mathrm{CO}$, $\mathrm{H}_{2} \mathrm{CO}$ and $\mathrm{C}_{2} \mathrm{H}_{4}$ from commercial marine shipping during 
TexAQS 2006, submitted to Journal of Geophysical Research, 2009) show that bulk freighter and tankers emitted considerably more $\mathrm{NO}_{2}$ per unit fuel burned than do underway container carriers, passenger vessels, or tugs. Emission of $\mathrm{SO}_{2}$ was higher for all cargo vessels than for passenger ships or tugs, which is due to the use of higher sulfur residual fuels by cargo ships and lower sulfur distillate fuels by passenger ships and tugs. There is broad general agreement between these data and published emission factors, although variability is large for both cases. Marine vessel emission factors for $\mathrm{NO}_{2}$ and $\mathrm{SO}_{2}$ are considerably larger than for stationary sources such as coalfired or gas-fired power plants, which indicates that emissions from commercial marine vessels likely make significant contributions in coastal areas and ports.

[51] Lack et al. [2008] measured particulate emission factors for these same ships, and found the emission of black carbon (BC) from these diesel engine powered vessels was a factor of 2 greater than previous estimates. They found that tugs emit more $\mathrm{BC}$ than do large cargo vessels, which has particular significance for the Houston-Galveston region since these vessels constitute a large fraction of total ship traffic there. Lack et al. [2009] also found that the chemical composition (sulfate and organic material) and aerosol properties such as single-scatter albedo and particulate water uptake of ship exhaust particulates was directly related to the fuel sulfur content.

5.1.4. Biogenic Emissions in the Eastern Texas Region

[52] C. Warneke et al. (Biogenic emission measurement and inventories: Determination of biogenic emissions in the eastern United States and Texas and comparison with biogenic emission inventories, submitted to Journal of Geophysical Research, 2009) utilize airborne measurements of isoprene and monoterpenes conducted during the TexAQS 2006 campaign along with results from the SOS 1999, TexAQS 2000, and ICARTT 2004 studies to evaluate the biogenic emission models BEIS3.12, BEIS3.13, MEGAN2 and WM2001. Two methods are used for the evaluation. First, the emissions are directly estimated from the ambient isoprene and monoterpene measurements assuming a wellmixed boundary layer and using calculated $\mathrm{OH}$ concentrations, and are compared with the emissions from the inventories extracted along the flight tracks using measured light and temperature. Second, BEIS3.12 is incorporated into the detailed transport model FLEXPART, which allows the isoprene and monoterpene mixing ratios to be calculated and compared to the measurements. The overall agreement for all inventories is within a factor of two and both methods give consistent results. MEGAN2 is in most cases higher, and BEIS3.12 and BEIS3.13 lower than the emissions determined from the measurements. Regions with clear discrepancies are identified. For example, an isoprene hot spot to the northwest of Houston, Texas, is expected from BEIS3 but not observed in the measurements. Interannual differences in emissions were also observed: the isoprene emissions estimated from the measurements in Texas in 2006 may have been $50 \%$ lower than in 2000 under the same light and temperature conditions.

5.1.5. Ammonia Emissions in the Eastern Texas Region

[53] Ammonium nitrate aerosol is formed from the reaction of gas-phase ammonia $\left(\mathrm{NH}_{3}\right)$ and nitric acid $\left(\mathrm{HNO}_{3}\right)$.
High-time-resolution $(\sim 1 \mathrm{~s}$ average $) \mathrm{NH}_{3}$ measurements were made from the WP-3D aircraft by a Chemical Ionization Mass Spectrometry technique [Nowak et al., 2007] and from the Ronald H. Brown by quantum cascade laser absorption (S. C. Herndon et al., manuscript in preparation, 2009) with the goals of characterizing sources and examining the effect of $\mathrm{NH}_{3}$ on atmospheric aerosol formation.

[54] Mixing ratios measured aboard the WP-3D aircraft over the Houston urban area ranged from 0.2 to $3 \mathrm{ppbv}$, and generally decreased with increasing altitude (J. B. Nowak et al., manuscript in preparation, 2009). Though infrequent, plumes with $\mathrm{NH}_{3}$ mixing ratios from 5 to greater than $50 \mathrm{ppbv}$ were observed in the boundary layer below $1 \mathrm{~km}$ altitude. Corresponding increases in fine particle volume and particulate nitrate $\left(\mathrm{NO}_{3}^{-}\right)$and decreases in $\mathrm{HNO}_{3}$ mixing ratios typically accompanied the large observed $\mathrm{NH}_{3}$ enhancements. These correlated variations are consistent with ammonium nitrate formation. $\mathrm{NH}_{3}$ mixing ratios as high as several hundred ppbv were measured in the HSC from the Ronald H. Brown. Up to this point, it has proven difficult to trace the sources of plumes with high $\mathrm{NH}_{3}$ concentrations to particular industrial facilities.

[55] Power plants that have installed Selective Catalytic Reduction (SCR) units constitute a possible $\mathrm{NH}_{3}$ source. This process adds aqueous $\mathrm{NH}_{3}$ to the exhaust gases as a reagent to decrease $\mathrm{NO}_{\mathrm{x}}$ emissions. $\mathrm{NH}_{3}$ "slippage," i.e., unwanted emissions of $\mathrm{NH}_{3}$ into the atmosphere, occurs when exhaust gas temperatures are too low for the SCR reaction to proceed to completion, or when excess $\mathrm{NH}_{3}$ is added. The W.A. Parish electric generating facility is equipped with these units, and the WP-3D aircraft sampled the Parish plume on numerous flights during TexAQS 2006. Clear enhancements of $\mathrm{CO}_{2}, \mathrm{NO}_{y}$, and $\mathrm{SO}_{2}$ were observed, but no difference in $\mathrm{NH}_{3}$ mixing ratios could be discerned during the plume transect. The lack of $\mathrm{NH}_{3}$ enhancement in the power plant plumes sampled by the WP-3D indicates that $\mathrm{NH}_{3}$ slippage was not significant during any of the TexAQS 2006 plume transects.

\subsection{Air Quality: Measurements and Observational Based Analyses}

5.2.1. Role of Nitrate Radicals and $\mathrm{N}_{2} \mathrm{O}_{5}$

[56] Hydrolysis of $\mathrm{N}_{2} \mathrm{O}_{5}$ provides a nonphotochemical mechanism for conversion of $\mathrm{NO}_{\mathrm{x}}$ to soluble nitrate $\left(\mathrm{NO}_{3}^{-}\right)$ that can be competitive with, or even exceed, photochemical oxidation of $\mathrm{NO}_{2}$ by $\mathrm{OH}$. Formation of $\mathrm{N}_{2} \mathrm{O}_{5}$ proceeds through oxidation of $\mathrm{NO}_{2}$ to $\mathrm{NO}_{3}$ by ozone and further reaction of $\mathrm{NO}_{3}$ with $\mathrm{NO}_{2}$. The process is only important in the dark because of the photochemical instability of $\mathrm{NO}_{3}$. Hydrolysis of $\mathrm{N}_{2} \mathrm{O}_{5}$ occurs heterogeneously via uptake to aerosol. Its rate therefore depends on the availability of aerosol surface area and on the heterogeneous uptake coefficient of $\mathrm{N}_{2} \mathrm{O}_{5}$ to aerosol, $\gamma\left(\mathrm{N}_{2} \mathrm{O}_{5}\right)$. Both are highly variable, making the dark loss of $\mathrm{NO}_{\mathrm{x}}$ more difficult to accurately predict than the photochemical loss via $\mathrm{OH}$ reaction.

[57] Measurements of $\mathrm{NO}_{3}$ and $\mathrm{N}_{2} \mathrm{O}_{5}$ from the NOAA WP-3D aircraft on night flights allowed the direct determination of the overall loss rates for $\mathrm{N}_{2} \mathrm{O}_{5}$ and for its heterogeneous uptake coefficient [Brown et al., 2009]. The $\gamma\left(\mathrm{N}_{2} \mathrm{O}_{5}\right)$ values derived from the field measurements 
were considerably smaller than predictions from current model parameterizations based on laboratory data. The result is consistent with the one set of previous aircraft determinations of $\mathrm{N}_{2} \mathrm{O}_{5}$ heterogeneous hydrolysis rates in the northeast United States [Brown et al., 2006], which showed small $\gamma\left(\mathrm{N}_{2} \mathrm{O}_{5}\right)$ on mixed organic/neutral ammonium sulfate aerosol. This aerosol type was prevalent during TexAQS 2006. Lifetimes of $\mathrm{N}_{2} \mathrm{O}_{5}$ were long enough to allow overnight transport of reactive nitrogen in this form from large $\mathrm{NO}_{\mathrm{x}}$ emission sources in the Houston area to rural regions of eastern Texas.

\subsubsection{Role of Halogen Radicals}

[58] The TexAQS-GoMACCS 2006 study provided the first ambient measurements of nitryl chloride, $\mathrm{ClNO}_{2}$ [Osthoff et al., 2008]. This active chlorine species is produced in the reaction of $\mathrm{N}_{2} \mathrm{O}_{5}$ with chloride-containing aerosol particles, and was observed at mixing ratios as high as $1.2 \mathrm{ppbv}$, much higher than models had previously predicted. $\mathrm{ClNO}_{2}$ is photolyzed to form chlorine atoms in the morning hours when other sources of reactive radicals are low, which can "kick start" the ozone formation process, an effect that was demonstrated by a simple box model described by Osthoff et al. [2008]. $\mathrm{ClNO}_{2}$ also acts to preserve $\mathrm{NO}_{2}$ against the loss to particles through $\mathrm{N}_{2} \mathrm{O}_{5}$ heterogeneous uptake. This $\mathrm{NO}_{2}$ is then available for photochemical reaction the next morning.

[59] A regional modeling study using the TexAQSGoMACCS $2006 \mathrm{ClNO}_{2}$ observations as a starting point [Simon et al., 2009] found only modest (up to $1.5 \mathrm{ppbv}$ ) effects on ozone in the $\mathrm{HGB}$ area if the $\mathrm{CINO}_{2}$ is produced only in the surface layer at the coast, i.e., where the measurements were made. The $\mathrm{ClNO}_{2}$ ambient measurements, and subsequent laboratory studies (J. M. Roberts et al., manuscript in preparation, 2009) showed that significant $\mathrm{N}_{2} \mathrm{O}_{5}$ to $\mathrm{ClNO}_{2}$ conversion takes place at chloride concentrations as low as $0.05 \mathrm{M}$. In addition, studies of $\mathrm{N}_{2} \mathrm{O}_{5}$ uptake on substrates of low $\mathrm{pH}(<2)$ show that molecular chlorine can be produced from this reaction directly [Roberts et al., 2008]. Thus, the potential of this chemistry to affect urban photochemistry deserves further study. Although $\mathrm{ClNO}_{2}$ was not measured from the WP-3D aircraft, examination of its potential formation from $\mathrm{N}_{2} \mathrm{O}_{5}$ uptake to chloride-containing aerosol aloft showed that halogen activation by this mechanism may have been substantial in some $\mathrm{NO}_{\mathrm{x}}$ plumes.

\subsubsection{Photochemical Ozone Production}

[60] The NOAA WP-3D aircraft conducted extensive studies of anthropogenic emissions and the subsequent ozone and reactive nitrogen photochemistry in the continental boundary layer downwind of the Houston, Texas urban area. Measurements of ozone, $\mathrm{CO}, \mathrm{NO}_{\mathrm{x}}$, and $\mathrm{NO}_{\mathrm{x}}$ oxidation products were made during 65 crosswind transects of plumes from the greater Houston urban/industrial area performed on 10 daytime under a variety of meteorological conditions [Neuman et al., 2009]. On all days when the $\mathrm{CO}$ to $\mathrm{NO}_{\mathrm{y}}$ enhancement ratios in downwind plume transects were unambiguously interpretable, the ozone production efficiency derived from observed $\mathrm{O}_{3}$ to $\mathrm{NO}_{y}-\mathrm{NO}_{x}$ enhancement ratios averaged $5.9 \pm 1.2$ in coalesced plumes from urban and petrochemical industrial sources in Houston. Higher values were observed in isolated plumes downwind from petrochemical facilities located along the Houston ship channel.

\subsection{Air Quality: Meteorological and Modeling Studies} 5.3.1. Interregional and Long-Range Transport

[61] During the last decade, emission control measures have successfully reduced the highest ozone concentrations observed in the urban areas of Texas as well as elsewhere in the United States [e.g., Environmental Protection Agency, 2004]. During this same period the basis of the ozone standard was changed from a maximum 1-h average to a maximum 8-h average. Both of these changes increased the importance of the background ozone contributions to violations in urban areas. Thus, urban air quality control strategies increasingly depend upon understanding the sources of the background ozone and the mechanisms and magnitude of its interregional and long-range transport into urban areas.

[62] Several studies during TexAQS II focused on the contribution from background ozone transport into the eastern Texas urban areas [Kemball-Cook et al., 2009; Langford et al., 2009; Pierce et al., 2009; R. M. Hardesty et al., manuscript in preparation, 2009; D. W. Sullivan, Regional ozone and particulate matter concentrations during the Second Texas Air Quality Study, submitted to Journal of Geophysical Research, 2009]. These papers define "background ozone" somewhat differently and utilize different approaches to determine that background, but they all present findings consistent with the conclusion that the transport of background ozone can predominate over in situ production within the urban area, even during exceedance conditions. For example, Langford et al. [2009] and KemballCook et al. [2009] report background ozone values spanning the approximate ranges of 15 to $80 \mathrm{ppbv}$ and 22 to $72 \mathrm{ppbv}$, respectively. Since the ozone standard has recently been lowered to $75 \mathrm{ppbv}$ for an 8-h maximum daily average, it is clear that background ozone alone can bring an area close to the exceedance level.

[63] A regional model [Kemball-Cook et al., 2009] and a global model [Pierce et al., 2009] also provided estimates of background ozone. Both models predict enhanced background ozone concentrations associated with air masses transported into eastern Texas from upwind regions. Both models have some success in reproducing the magnitude and temporal variability of background ozone determined by the experimental based studies, and agree that areas from the entire eastern United States contribute to the eastern Texas background ozone.

\subsubsection{Ozone Transport Downwind of Source Regions}

[64] C. J. Senff et al. (manuscript in preparation, 2009) analyzed airborne lidar ozone measurements to estimate the horizontal flux of ozone in urban plumes downwind of Houston and Dallas. Aircraft transects across the plumes downwind of the source regions enabled calculation of total ozone in the plume. By combining the measured plume ozone with the local wind speed extrapolated from multiple wind profiler observations, the net flux of ozone into rural areas downwind of the urban centers was computed. Three Houston cases from the 2006 study were compared with similar measurements from TexAQS 2000, as well as with a single 2006 Dallas case. In Houston, highest flux levels were measured for cases when winds were southerly and 
indicated significant transport of ozone into rural areas north of Houston. The limited data available indicate that the net ozone flux transported out of Houston averaged about a factor of two to three larger than the corresponding flux from Dallas.

\subsubsection{Boundary Layer Effects}

[65] On the Ronald H. Brown, a Doppler lidar was used to measure mixing heights and profiles of wind speed and turbulence while the ship was in operation [Tucker et al., 2009]. The results were used to investigate the effects of mixing heights and turbulent mixing on shipboard in situ chemistry and aerosol measurements. Observations showed a significant difference in the diurnal cycle of mixing heights for ship locations in or near the Houston Ship Channel, in Galveston Bay, or in the Gulf of Mexico. Additionally, the observations showed the necessity of taking into account mixing layer and turbulence characteristics in the interpretation of the chemical species and aerosol observations. Daytime planetary boundary layer (PBL) heights also were determined from the NASA King Air with the HSRL. Appendix A provides some details of this determination. The mean (std. dev.) PBL height was $1.3 \mathrm{~km}(0.48 \mathrm{~km})$ while the mean entrainment zone thickness was $200 \mathrm{~m}(140 \mathrm{~m})$. PBL heights over the Gulf of Mexico were typically several hundred meters lower than the PBL heights over land.

\subsubsection{Effect of Local Wind on Peak Ozone Concentration}

[66] Ozone concentrations measured by the network of surface stations around Houston and by the airborne ozone lidar were analyzed by R. M. Banta et al. (manuscript in preparation, 2009) to assess the role of local winds on peak ozone concentrations. They found that vector wind speed was inversely proportional to daily peaks in ozone concentrations in the Houston area. Hardesty et al. (manuscript in preparation, 2009) also investigated the correlation between high ozone in the Houston urban plume, as measured by the airborne lidar, and wind speed and found a similar result. In both studies the depth of the mixing layer was shown to have little impact on ozone concentrations investigated.

\subsubsection{Ozone and $\mathbf{P M}_{2.5}$ Model Forecasts}

[67] McKeen et al. [2009] evaluate seven real-time air quality forecast models (AQFMs) against observations from the AIRNow surface network and NOAA WP-3 aircraft data collected over eastern Texas during the TexAQS 2006 field study. Forecast performance statistics for surface $\mathrm{O}_{3}$ and $\mathrm{PM}_{2.5}$ are presented for each model as well as the model ensemble, and these statistics are compared to previous realtime forecast evaluations during the ICARTT/NEAQS 2004 field study in New England. Surface maximum 8-h daily average $\mathrm{O}_{3}$ forecasts for eastern Texas during the summer of 2006 show a marked improvement in correlations, bias and RMSE-based skill scores for all models compared to similar forecasts for New England during the summer of 2004. Though some of this improvement may be due to the smaller region, and more spatially uniform meteorological forcing during the 2006 study, improvements in all the AQFM formulations and emissions have also occurred since 2004. As found in the 2004 study, the ensemble mean of the model forecasts outperforms any single model. In contrast to the bulk statistical measures only the two Canadian AQFMs were able to forecast the 85 ppbv 8-h average $\mathrm{O}_{3}$ exceedances better than persistence. All other AQFMs as well as the ensemble mean showed far less skill at threshold exceedance predictions compared to New England in 2004. Considering the ensemble mean as the best, most representative realization of the model suite, the number of $85 \mathrm{ppbv}$ $\mathrm{O}_{3}$ exceedances was severely underestimated for the Houston region, but much less so for the Dallas/Fort Worth region. This preferential underprediction for Houston is consistent with low ethene emission biases for Houston.

[68] Statistical evaluations of the $\mathrm{PM}_{2.5}$ forecasts, based on 24-h averages, are much less reliable during TexAQS 2006 compared to ICARTT/NEAQS-2004. All of the models except one are biased low. Correlations and RMSE-based skill for all models, and their ensemble, are much smaller in 2006 compared to 2004 and fall well below persistence. The low biases suggest a missing component to the $\mathrm{PM}_{2.5}$ forecasts. The daytime aircraft comparisons of $\mathrm{PM}_{2.5}$ yield a different picture, similar to aircraft comparisons in 2004, with most models showing positive bias compared to the PM volume measurements. This is despite the fact that all models severely underpredict organic- $\mathrm{PM}_{2.5}$, the dominant component of ambient $\mathrm{PM}_{2.5}$. This discrepancy can be explained by an overestimation of primary, unspeciated $\mathrm{PM}_{2.5}$ emissions within the inventories compensating the lack of secondary organic aerosol formation within the models.

[69] Experience with air quality model forecasts during TexAQS 2006 and in New England in 2004 suggest that there are at least three essential requirements for improving photochemical model forecasts. First, improved emission inventories are required for AQFMs (and as well for diagnostic models); second, an improved understanding of the chemical mechanisms responsible for the formation of secondary organic aerosols must be developed and incorporated into the model chemical mechanisms; and third, sophisticated data assimilation of meteorological and even chemical observations is likely required.

\subsection{Aerosol Formation, Composition, and Chemical Processing}

\subsubsection{In Situ Measurements of Aerosol Composition} and Evolution

[70] Aerosols over the Gulf of Mexico during August 2006 were heavily impacted by dust from the Saharan Desert and acidic sulfate and nitrate from ship emissions [Bates et al., 2008]. The mass loadings of this "background" aerosol were much higher than typically observed in the marine atmosphere and substantially impacted the radiative energy balance over the Gulf of Mexico as well as the particulate matter (PM) air quality in the HoustonGalveston area. As this background aerosol moved onshore, local urban and industrial sources added an organic rich submicrometer component. Hydrocarbon-like organic aerosol concentrations and $\mathrm{CO}$ mixing ratios were highest in the early morning when the source was strong (automobile traffic) and mixing was limited (shallow, stable boundary layer) and then decreased during the day as the boundary layer mixing height increased [Bates et al., 2008]. Sulfate and oxygenated-organic aerosol concentrations followed the opposite pattern. Concentrations were lowest in the shallow, stable nocturnal boundary layer and increased during the day as the boundary layer mixing height increased, reflecting their secondary source. Secondary organic aerosol (SOA) formation and growth in the urban plumes of 
Houston and Dallas were similar to plumes sampled downwind of urban areas in NE United States. Higher SOA growth rates were measured downwind of the Houston Ship Channel, most likely a result of the higher VOC mixing ratios [Bahreini et al., 2009]. However, the model predicted amounts of SOA were on average a factor of 2-3 lower than the measurements [Bahreini et al., 2009]. Positive matrix factorization analysis of organic functional groups and trace metals attributed most of the organic carbon in the measured ambient aerosol directly to oil and biomass combustion emissions [Russell et al., 2009].

\subsubsection{Remote Sensing of Aerosol Composition}

[71] HSRL measurements of aerosol properties acquired during TexAQS/GoMACCS were used to identify aerosol types and apportion aerosol optical thickness to each aerosol type (R. Ferrare et al., Airborne high spectral resolution lidar aerosol measurements during MILAGRO and TexAQS/ GoMACCS, paper presented at Ninth Conference on Atmospheric Chemistry, American Meteorological Society, San Antonio, Texas, 2007, available at http://ams.confex.com/ ams/pdfpapers/119758.pdf). Aerosol depolarization ratio at $532 \mathrm{~nm}$, backscatter color ratio (backscatter at $532 \mathrm{~nm} /$ backscatter at $1064 \mathrm{~nm}$ ), extinction-to-backscatter ratio ("lidar ratio"), and the spectral dependence of aerosol depolarizations (i.e., (depolarization at 1064)/(depolarization at $532 \mathrm{~nm}$ )) were used in a cluster analysis procedure to identify classes of aerosol as defined by observed natural groupings of intensive optical properties. The optical properties of each cluster were then used to infer which aerosol type(s) most closely matched that cluster. The aerosol properties observed during TexAQS were usually characteristic of spherical aerosols associated with biomass burning and/or urban pollution. These urban/biomass type aerosols accounted for about $73 \%$ of the aerosol optical thickness measured by the HSRL during TexAQS/ GoMACCS. This is in contrast to the Mexico City region during the Megacity Initiative: Local and Global Research Observations (MILAGRO) mission in March 2006, when the aerosol type consisting of a mix of dust and urban aerosols accounted for over half of the aerosol optical thickness (AOT) measured by the HSRL. The aerosol types observed during TexAQS/GoMACCS were also similar to the aerosol types measured by the HSRL over the eastern United States. However, there were a few occasions during TexAQS when nonspherical dust aerosols were observed. In particular, Saharan dust was observed over the Gulf of Mexico southeast of Houston on 28 and 29 August [Liu et al., 2008].

\subsubsection{In Situ Measurements of Aerosol Optical and} Hygroscopic Properties

[72] Massoli et al. [2009] measured aerosol optical and hygroscopic properties on board the NOAA R/V Ronald $H$. Brown. Aerosols from fresh traffic emissions had the lowest single scattering albedos $(\omega)$ and were the least hygroscopic (lowest $\gamma$ values). The more aged aerosols had progressively larger values of $\omega$ and $\gamma$, and sulfate-dominated aerosols exhibited the highest values of $\omega$ and $\gamma$. D. P. Atkinson et al. (Comparison of in situ and columnar spectral measurements during TexAQS-GoMACCS 2006: Testing parameterizations for estimating aerosol fine mode optical properties, submitted to Journal of Geophysical Research, 2009) measured aerosol extinction on the Moody Tower and used the combined Moody Tower and Ronald H. Brown data sets to identify two periods when the Houston and Galveston areas were affected by large-scale aerosol events, one of which was coarse mode dominated and one fine mode dominated. They then compared the in situ measured fine mode fraction of extinction and fine mode effective radius with that obtained through various AERONET data processing algorithms.

\subsection{Aerosol Cloud and Radiative Effects}

5.5.1. Aerosols as CCN

[73] Lance et al. [2009] analyzed in situ cloud condensation nuclei $(\mathrm{CCN})$ measurements obtained on the CIRPAS Twin Otter, focusing in detail on a CCN closure study within and downwind of the Houston regional plume and over the Houston Ship Channel. CCN closure was evaluated by comparing measured $\mathrm{CCN}$ concentrations with those predicted on the basis of measured aerosol size distributions and Aerosol Mass Spectrometer (AMS) particle composition. Generally, CCN concentrations were overpredicted by $3 \%$ to $36 \%$. It is hypothesized that variation in the externally mixed fraction of the aerosol accounts for much of the variability in the $\mathrm{CCN}$ closure, while the composition of the internally mixed fraction largely controls the over prediction bias.

[74] Quinn et al. [2008] measured CCN aboard the NOAA R/V Ronald H. Brown and showed that the mass fraction of hydrocarbon-like organic aerosol (HOA) explained $40 \%$ of the variance in the critical diameter for particle activation at $0.44 \%$ supersaturation. In locations impacted by urban, industrial, and marine vessel emissions, HOA dominated the mass in the sub-200-nm size range.

\subsubsection{Aerosol-Cloud Relationships in Continental Shallow Cumulus}

[75] CIRPAS Twin Otter measurements in the Houston region were used to study the effect of variations in aerosol concentration on the properties of continental warm cumulus clouds. Fourteen intensive cloud measurement flights included three in which isolated cumulus clouds of sufficient size and lifetime existed to allow detailed sampling; the other 11 cases involved scattered cumuli that yielded statistical properties over the cloud field [Lu et al., 2008]. Cloud droplet number concentration was found to be clearly proportional to the subcloud accumulation mode aerosol number concentration. Cloud liquid water content, cloud droplet number concentration, and cloud top effective radius exhibited subadiabaticity resulting from entrainment mixing processes. The degree of LWC subadiabaticity was found to increase with cloud depth. It is estimated that owing to entrainment mixing, cloud LWP, effective radius, and cloud albedo were decreased by $50-85 \%, 5-35 \%$, and $2-26 \%$, respectively, relative to adiabatic values of a plane-parallel cloud. The observations are used to develop cloud top LWC and drop effective radius parameterizations that should prove useful for representation of these small cumulus clouds in larger-scale models.

\subsubsection{Large Eddy Simulation of Aerosol-Cloud Relationships in Continental Shallow Cumulus and Comparison With Measurements}

[76] On the basis of aircraft sampling strategy and availability of data, five research flights of the CIRPAS Twin Otter were deemed most suitable for large eddy simulation (LES) modeling. The LES model was coupled to a bin 
microphysical model representing warm cloud processes, a radiation model, and a land surface model over a $12.8 \mathrm{~km} \times$ $12.8 \mathrm{~km} \times 5 \mathrm{~km}$ domain (grid size $100 \mathrm{~m}$ in the horizontal and $50 \mathrm{~m}$ in the vertical). The model was initiated with observed environmental profiles. The simulations generated an ensemble of thousands of cumulus clouds for statistically meaningful comparisons with the observed clouds. Normalized frequency distributions of simulated and observed parameters including liquid water content, drop number concentration, drop effective radius, updraft velocity, and the distribution of cloud sizes, were shown to be in good agreement [X. Jiang et al., 2008]. These comparisons suggest that the LES model is able to successfully simulate both the microphysical and macrophysical properties of the cloud fields observed during GoMACCS.

\subsubsection{Effect of Aerosol on Measured and Modeled Three-Dimensional Spectral Irradiance in Broken Cloud Fields}

[77] Schmidt et al. [2009] compared measured solar spectral irradiance from broken boundary layer clouds embedded in moderately to heavily polluted air masses with modeled irradiance using three-dimensional radiative transfer applied to the output of large eddy simulation [H. Jiang et al., 2008]. Upwelling and downwelling moderate resolution irradiance spectra from $380 \mathrm{~nm}$ to $2150 \mathrm{~nm}$ were measured aboard the CIRPAS Twin Otter. The model reproduced the measured irradiance only when interstitial aerosol particles were included in the simulations. The aerosol particles enhanced fractional absorption in the layer by $20 \%$ for the case examined in this study. The simulations allowed for the discrimination between true and apparent forcing and the results showed that aerosol particles increased the relative radiative forcing at the surface by as much as $8 \%$. These findings represent an important new mechanism that is not represented in any current assessment of aerosol (either direct or indirect) cloud radiative forcing. In addition, the good comparison between LES-modeled and measured irradiance fields provides confidence that the LES represents not only the microphysical and macrophysical cloud properties described in section 5.5.3, but also their radiative response to aerosol.

\section{Conclusions}

[78] The measurements collected during TexAQS II and the shorter TexAQS 2006/GoMACCS intensive period provide very useful data sets, which have only been partially examined by the analyses presented in this special journal section, and briefly summarized in this paper. The data are available to the atmospheric chemistry community for further analysis, and future papers are planned that will extend the results presented here. Two present results are worthy of particular emphasis. First, despite decreases in actual HRVOC emissions and some improvements in inventory estimates since the TexAQS 2000 study, the current Houston area emission inventories still underestimate HRVOC emissions by approximately 1 order of magnitude. Second, the background ozone transported into the urban areas of eastern Texas, which represents the minimum ozone concentration that is likely achievable through only local controls, can approach or exceed the current National Ambient Air Quality Standard of 75 ppbv for an 8-h aver- age. These findings have broad implications for air quality strategies in eastern Texas.

\section{Appendix A: Mobile Platform Instrument Payloads and Deployment Details}

[79] The NOAA WP-3D aircraft was instrumented to study aerosol composition and gas-phase chemical transformations. The aircraft operated from the PBL up to $6.5 \mathrm{~km}$ and had sufficient range to sample throughout eastern Texas and the Gulf of Mexico while based at Ellington Field in Houston, Texas, from 31 August through 13 October. Tables A1a and A1b summarize the characteristics of the WP-3D instrumentation, and Table A2 and Figure A1 summarize the TexAQS II/GoMACCS flights.

[80] The NOAA Twin Otter aircraft was flown with a downward-looking lidar to characterize the regional boundary layer structure of ozone and aerosol backscatter (R. J. Alvarez II et al., manuscript in preparation, 2009). Observations were used to identify and track the Houston urban plume, estimate the amount of ozone exported from Houston and Dallas, and investigate the relationship between ozone concentration and boundary layer structure. The aircraft typically flew just above the boundary layer to produce vertical profiles of boundary layer ozone concentration and aerosol backscatter with a horizontal resolution of $600 \mathrm{~m}$ and vertical resolutions of $90 \mathrm{~m}$ (ozone) and $6 \mathrm{~m}$ (aerosol backscatter). To improve precision, the ozone lidar data are reported with a 450-m vertical running average; more details are given by Alvarez et al. (manuscript in preparation, 2009). The Twin Otter was on site in southeast Texas from 1 August to 13 September during which time it obtained roughly $70 \mathrm{~h}$ of ozone/aerosol observations over 21 flights. Table A3 and Figure A2 summarize the TexAQS/ GoMACCS Twin Otter flights, showing the emphasis on flights around Houston.

[81] The NOAA Research Vessel Ronald H. Brown departed Charleston, South Carolina on 27 July 2006, arriving initially in Galveston, Texas, on 2 August 2006. The cruise track included passages into Port Arthur/Beaumont, Matagorda Bay, Freeport Harbor, Galveston Bay to Barbours Cut (15 transits), and the Houston Ship Channel (4 transits). The cruise ended in Galveston, Texas, on 11 September 2006. Approximately $50 \%$ of the sampling time was spent in the Gulf of Mexico and 50\% within the interior waters of Texas. The cruise tracks are shown in Figure 1 of Bates et al. [2008]. The ship was instrumented to measure an extensive set of in situ gas and aerosol parameters as well as many remotely sensed parameters (Table A4). Radiosondes (2-8 times per day) and ozonesondes (once per day) also were launched from the ship.

[82] The CIRPAS Twin Otter Aircraft was based at Ellington Field in Houston, Texas, during August-September 2006. The aircraft payload consisted of a wide array of instrumentation for aerosol and cloud physical, chemical, and radiative characterization (Table A5). The general focus of the mission was on characterizing aerosol and cloud properties, from within the boundary layer up to the free troposphere. A variety of air mass types was sampled during this study, including plumes from coal-fired power plants, air over and downwind of the Houston Ship Channel, and air over the Gulf of Mexico. Table A6 lists the research 
Table A1a. NOAA WP-3D Aircraft Instrumentation for Gas-Phase Measurements

\begin{tabular}{|c|c|c|c|c|c|}
\hline Species/Parameter & Reference & Technique & $\begin{array}{c}\text { Time } \\
\text { Resolution, s }\end{array}$ & $\begin{array}{l}\text { Inaccuracy } \\
\text { (1 sigma) }\end{array}$ & $\begin{array}{l}\text { Imprecision } \\
\text { (1 sigma })\end{array}$ \\
\hline NO & Ryerson et al. [1999] & $\begin{array}{l}\mathrm{O}_{3} \text {-induced chemiluminescence } \\
\text { (CL) }\end{array}$ & 1 & $5 \%$ & $0.015 \mathrm{ppbv}$ \\
\hline $\mathrm{NO}_{2}$ & Ryerson et al. [2000] & UV photolysis-CL & 1 & $9 \%$ & $0.040 \mathrm{ppbv}$ \\
\hline $\mathrm{NO}_{\mathrm{y}}$ & Ryerson et al. [1999] & $\mathrm{Au}$ converter-CL & 1 & $12 \%$ & $0.200 \mathrm{ppbv}$ \\
\hline $\mathrm{O}_{3}$ & Ryerson et al. [1998] & NO-induced CL & 1 & $3 \%$ & $0.050 \mathrm{ppbv}$ \\
\hline $\mathrm{CO}$ & Holloway et al. [2000] & VUV resonance fluorescence & 1 & $5 \%$ & $0.500 \mathrm{ppbv}$ \\
\hline $\mathrm{CO}_{2}$ & Daube et al. [2002] & NDIR absorption & 1 & $0.08 \mathrm{ppmv}$ & $0.110 \mathrm{ppmv}$ \\
\hline $\mathrm{SO}_{2}$ & Ryerson et al. [1998] & Pulsed UV fluorescence & 3 & $10 \%$ & $0.300 \mathrm{ppbv}$ \\
\hline $\mathrm{C}_{2}-\mathrm{C}_{10} \mathrm{NMHCs}$ & Schauffler et al. [1999] & whole air sample/GC-FID & $8-30^{\mathrm{a}}$ & $5-10 \%$ & 0.003 ppbv \\
\hline $\mathrm{C}_{1}-\mathrm{C}_{2}$ halocarbons & Schauffler et al. [1999] & whole air sample/GC-MS & $8-30^{\mathrm{a}}$ & $2-20 \%$ & $<0.050 \mathrm{ppbv}$ \\
\hline $\mathrm{C}_{1}-\mathrm{C}_{5}$ alkyl nitrates & Schauffler et al. [1999] & whole air sample/GC-MS & $8-30^{\mathrm{a}}$ & $10-20 \%$ & $0.0002 \mathrm{ppbv}$ \\
\hline $\begin{array}{l}\text { isoprene, monoterpenes, } \mathrm{CH}_{3} \mathrm{CN} \text {, } \\
\text { oxygenates, and aromatics }\end{array}$ & de Gouw et al. [2003] & $\begin{array}{l}\text { Proton transfer reaction mass } \\
\text { spectrometry (PTRMS) }\end{array}$ & 17 & $10-20 \%$ & $<0.250 \mathrm{ppbv}$ \\
\hline $\mathrm{C}_{2} \mathrm{H}_{4}$ & de Gouw et al. [2009] & $\begin{array}{l}\text { laser photoacoutic absorption } \\
\text { spectroscopy (LPAS) }\end{array}$ & 20 & $10 \%$ & $0.700 \mathrm{ppbv}$ \\
\hline $\mathrm{HCHO}$ & Weibring et al. [2007] & $\begin{array}{l}\text { Difference frequency generation } \\
\text { tunable diode laser absorption }\end{array}$ & 1 & $13 \%$ & $0.220 \mathrm{ppbv}$ \\
\hline $\begin{array}{l}\text { PAN, PPN, PiBN, APAN, } \\
\text { MPAN, MoPAN }\end{array}$ & Slusher et al. [2004] & $\begin{array}{l}\mathrm{I}^{-} \text {chemical ionization mass } \\
\text { spectrometry (CIMS) }\end{array}$ & 2 & $\begin{array}{l}30 \% \\
\quad(100 \% \text { for MPAN })\end{array}$ & $0.020 \mathrm{ppbv}$ \\
\hline $\mathrm{NO}_{3}, \mathrm{~N}_{2} \mathrm{O}_{5}$ & Dubé et al. [2006] & $\begin{array}{l}\text { Cavity ring-down spectroscopy } \\
\text { (CARDS) }\end{array}$ & 1 & $20 \%$ & $0.002 \mathrm{ppbv}$ \\
\hline $\mathrm{NH}_{3}$ & Nowak et al. [2007] & protonated acetone dimer CIMS & 1 & $25 \%$ & $0.080 \mathrm{ppbv}$ \\
\hline $\mathrm{HNO}_{3}$ & Neuman et al. [2002] & $\mathrm{SiF}_{5}^{-} \mathrm{CIMS}$ & 1 & $15 \%$ & $0.100 \mathrm{ppbv}$ \\
\hline $\mathrm{HO}_{2}+\mathrm{RO}_{2}$ & Eisele and Tanner [1993] & $\mathrm{NO}$ titration- $\mathrm{NO}_{3}^{-} \mathrm{CIMS}$ & 10 & $40 \%$ & $5 \times 10^{6} \mathrm{~cm}^{-3}$ \\
\hline $\mathrm{H}_{2} \mathrm{SO}_{4}$ & Eisele and Tanner [1993] & $\mathrm{NO}_{3}^{-} \mathrm{CIMS}$ & 10 & $30 \%$ & $1 \times 10^{6} \mathrm{~cm}^{-3}$ \\
\hline UV-VIS actinic flux & Stark et al. [2007] & $\begin{array}{l}\text { spectrally resolved radiometry } \\
\text { using hemispheric collectors } \\
\text { in zenith and nadir }\end{array}$ & 1 & $\begin{array}{l}15 \% \\
\quad\left(30 \% \text { for } \mathrm{jO}^{1} \mathrm{D}\right)\end{array}$ & \\
\hline Visible and IR irradiance & Pilewskie et al. [2003] & Solar Spectral Flux Radiometer & 1 & $3-5 \%$ & $0.2 \%$ \\
\hline $\mathrm{H}_{2} \mathrm{O}$ & & tunable diode laser spectrometry & 1 & $1.0^{\circ} \mathrm{C}$ & $0.3^{\circ} \mathrm{C}$ \\
\hline $\mathrm{H}_{2} \mathrm{O}$ & & chilled mirror hygrometry & 1 & $1.0^{\circ} \mathrm{C}$ & $1.0^{\circ} \mathrm{C}$ \\
\hline
\end{tabular}

${ }^{\mathrm{a}}$ Sampling time depends on aircraft altitude.

Table A1b. NOAA WP-3D Aircraft Instrumentation for Aerosol Measurements

\begin{tabular}{|c|c|c|c|c|}
\hline Species/Parameter & Reference & Technique & $\begin{array}{c}\text { Time } \\
\text { Resolution } \\
\end{array}$ & Notes \\
\hline $\begin{array}{l}\text { Aerosol number, size, and } \\
\text { volume distributions }\end{array}$ & $\begin{array}{l}\text { Brock et al. }[2000,2003] \\
\quad \text { Wilson et al. }[2004]\end{array}$ & $\begin{array}{l}\text { five parallel CPCs, and white and laser } \\
\text { light scattering with a low turbulence } \\
\text { inlet (LTI) }\end{array}$ & $1 \mathrm{~s}$ & $\begin{array}{l}0.004-8.3 \mu \mathrm{m} \text { physical } \\
\text { diameter }\end{array}$ \\
\hline Black carbon & Schwarz et al. [2008] & single-particle soot photometry & $1 \mathrm{~s}$ & $\begin{array}{l}\text { mixing state, mass, and } \\
\text { optical properties }\end{array}$ \\
\hline Cloud condensation nuclei & Lance et al. [2006] & $\begin{array}{l}\text { streamwise thermal gradient continuous } \\
\text { flow CCN counter }\end{array}$ & $1 \mathrm{~s}$ & $\begin{array}{l}\text { operated at multiple } \\
\text { supersaturations }\end{array}$ \\
\hline Aerosol bulk ionic composition & Weber et al. [2001] & $\begin{array}{l}\text { Particle into liquid sampling-ion } \\
\text { chromatography (PiLS-IC) }\end{array}$ & $3 \mathrm{~min}$ & $\begin{array}{l}\text { anion and cation data } \\
\text { in submicron range }\end{array}$ \\
\hline $\begin{array}{l}\text { Aerosol water-soluble organic } \\
\text { carbon }\end{array}$ & Sullivan et al. [2006] & $\begin{array}{l}\text { PiLS-total organic carbon detection } \\
\text { (PiLS-TOC) }\end{array}$ & $15 \mathrm{~s}$ & in submicron range \\
\hline $\begin{array}{l}\text { Aerosol chemical composition } \\
\text { (size-resolved, nonrefractory) }\end{array}$ & Bahreini et al. [2008] & Aerosol mass spectrometry (AMS) & $10 \mathrm{~s}$ & $\begin{array}{l}100 \% \text { transmission from } \\
0.055 \text { to } 0.360 \mu \mathrm{m} \\
\text { physical diameter }\end{array}$ \\
\hline
\end{tabular}


Table A2. NOAA WP-3D Flights

\begin{tabular}{|c|c|c|c|}
\hline $\begin{array}{l}\text { Flight } \\
\text { Number }\end{array}$ & Flight Description & $\begin{array}{l}\text { Date in } \\
2006\end{array}$ & $\begin{array}{l}\text { Takeoff-Landing } \\
\text { LST } \\
\end{array}$ \\
\hline 1 & $\begin{array}{l}\text { Transit from Tampa to Houston; Beaumont-Port Arthur (BPA) and } \\
\text { Houston-Galveston (HGA) plumes }\end{array}$ & 31 Aug & $1115-1530$ \\
\hline 2 & Oil platform emissions and processing in Gulf of Mexico & 11 Sep & $1005-1630$ \\
\hline 3 & $\begin{array}{l}\text { Houston and Dallas emissions and processing; coordinated with } \\
\text { NOAA Twin Otter and NASA King Air }\end{array}$ & 13 Sep & $1045-1645$ \\
\hline 4 & $\begin{array}{l}\text { Houston emissions and chemical processing; coordinated with } \\
\text { CIRPAS Twin Otter and NASA King Air }\end{array}$ & 15 Sep & $0950-1620$ \\
\hline 5 & Houston emissions; NE Texas power plants and aged Houston plume & 16 Sep & $0955-1630$ \\
\hline 6 & Houston urban, Parish power plant, isolated refineries & 19 Sep & $0950-1620$ \\
\hline 7 & BPA, Houston urban, Parish power plant, isolated refineries & 20 Sep & $0955-1615$ \\
\hline 8 & Houston urban and industrial plumes; Parish power plant & 21 Sep & $0950-1625$ \\
\hline 9 & Dallas, GMD tower, Big Brown, and Parish power plants & 25 Sep & $0945-1625$ \\
\hline 10 & Houston, Parish power plant, BPA, and Lake Charles, Louisiana plumes & 26 Sep & $0950-1635$ \\
\hline 11 & Houston, Parish power plant, Beaumont-Port Arthur & 27 Sep & $1245-1755$ \\
\hline 12 & Houston, Parish power plant, chemical processing into the night & 29 Sep & $1345-2010$ \\
\hline 13 & Houston, Parish power plant emissions and processing & 5 Oct & $0950-1620$ \\
\hline 14 & Houston, Parish power plant, Victoria and Seadrift & 6 Oct & $0950-1600$ \\
\hline 15 & Houston, Parish power plant, chemical processing into the night & 8 Oct & $1520-2200$ \\
\hline 16 & Oklaunion power plant at night & 10 Oct & $1720-2400$ \\
\hline 17 & Houston emissions and processing at night & 12 Oct & $1920-0005$ \\
\hline 18 & Transit from Houston to Tampa; Texas and Louisiana emissions & 13 Oct & $0945-1530$ \\
\hline
\end{tabular}

flights during GoMACCS, and Figure A3 shows the individual flight tracks.

[83] The NASA B200 King Air was instrumented with the NASA LaRC High Spectral Resolution Lidar (HSRL), which measures profiles of aerosol extinction, backscattering, and depolarization throughout the lower and middle troposphere. The HSRL technique [e.g., Shipley et al., 1983] takes advantage of the spectral distribution of the lidar return signal to discriminate aerosol returns from molecular returns and thereby enable independent retrievals of aerosol extinction and backscatter. (Standard backscatter lidars measure a combination of backscatter and extinction, and then retrieve the aerosol components of backscatter and extinction by assuming a value for the extinction-to-backscatter ratio, which can be quite variable.) The LaRC HSRL employs the high spectral resolution technique at $532 \mathrm{~nm}$ and the standard backscatter technique at $1064 \mathrm{~nm}$. In addition, the lidar is polarization-sensitive at both wavelengths (i.e., it measures the degree to which the backscatter light is depolarized from the linearly polarized state of the transmitted pulses), which enables discrimination between spherical and nonspherical particles. Hair et al. [2008] provide a detailed description of the NASA LaRC HSRL system.

[84] The LaRC HSRL provided vertically resolved measurements of both extensive and intensive aerosol parameters. Extensive parameters are optical parameters that are influenced by the amount (concentration) and type (size, composition, shape) of aerosol/cloud particles (e.g., extinction). Intensive parameters are those parameters that depend only on the nature of the particles and not on their quantity or concentration (i.e., properties that depend only on aerosol type). These parameters (with approximate nominal horizontal and vertical resolutions) are: (1) extensive parameters, with backscatter coefficient at 532 and $1064 \mathrm{~nm}(\mathrm{Dx} \sim 1 \mathrm{~km}$, $\mathrm{Dz} \sim 60 \mathrm{~m})$, extinction coefficient $532 \mathrm{~nm}(\mathrm{Dx} \sim 6 \mathrm{~km}$, $\mathrm{Dz} \sim 300 \mathrm{~m}$ ), and layer optical depth at $532 \mathrm{~nm}$ (integration of the extinction profile) and (2) intensive parameters, with extinction-to-backscatter ratio at $532 \mathrm{~nm}(\mathrm{Dx} \sim 6 \mathrm{~km}, \mathrm{Dz} \sim$ $300 \mathrm{~m}$ ), aerosol depolarization ratio at $532 \mathrm{~nm}$ and $1064 \mathrm{~nm}$ (Dx $\sim 1 \mathrm{~km}, \mathrm{Dz} \sim 60 \mathrm{~m}$ ), and aerosol wavelength dependence $(\mathrm{Dx} \sim 1 \mathrm{~km}, \mathrm{Dz} \sim 60 \mathrm{~m}$ ) (i.e., Ångström exponent

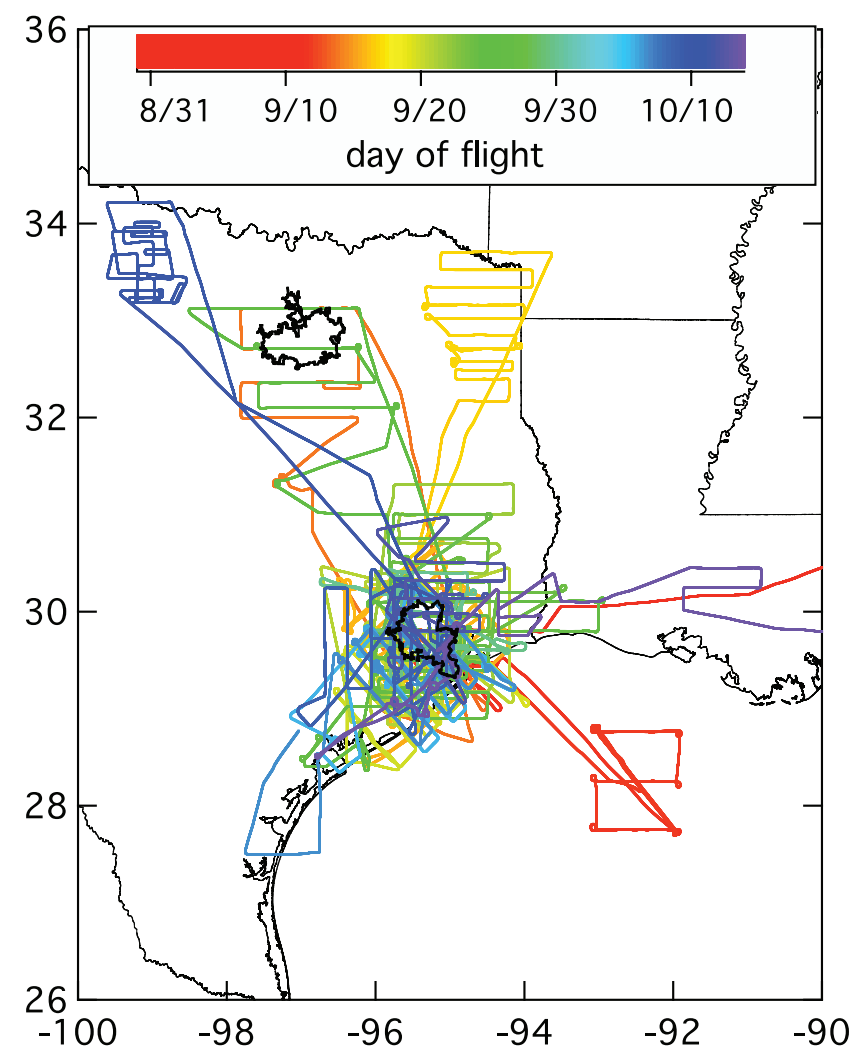

Figure A1. Flight tracks of the NOAA WP-3D aircraft during TexAQS II/GoMACCS. The heavier black outlines indicate the two major urban areas in the region: DallasFort Worth to the north and Houston to the south. 
Table A3. NOAA Twin Otter Flights

\begin{tabular}{clcc}
\hline $\begin{array}{c}\text { Flight } \\
\text { Number }\end{array}$ & \multicolumn{1}{c}{ Flight Description } & Date & Takeoff-Landing \\
LST
\end{tabular}

for aerosol backscatter, directly related to the backscatter color ratio).

[85] During TexAQS/GoMACCS, the NASA B200 King Air was based at Ellington Field, located about $25 \mathrm{~km}$ south of Houston, arrived on 27 August and departed on 28 September. Approximately $78 \mathrm{~h}$ of HSRL data were collected on 21 science flights (Table A7). The majority of the flights were over the Houston and Dallas regions; additional flights outside these regions were conducted along the CALIPSO ground tracks to acquire validation data for the CALIOP sensor (Figure A4). Table A7 also shows the flights that were coordinated or coincident with the other aircraft; Terra and/or Aqua MODIS, MISR, CALIPSO overpasses; and contained portions that included overpasses of the Moody Tower and/or NOAA Research Ship Ronald H. Brown.

[86] The HSRL also measured daytime planetary boundary layer (PBL) heights through an automated technique using a Haar wavelet covariance transform to identify the sharp gradients in aerosol backscatter located at the top of the boundary layer [Brooks, 2003]. Following the convention used by Davis et al. [2000] and Cohn and Angevine [2000], the altitude of the maximum covariance was used to identify the boundary layer height. The algorithm was modified for the TexAQS/GoMACCS region by: (1) limiting the altitude range to find the PBL height based on the PBL heights from the previous minute, (2) identifying the gradient at lowest altitude which exceeds a threshold, rather than the largest gradient, and (3) increasing the dilation values used in the wavelet analysis. PBL heights were also obtained by visual inspection of the HSRL backscatter profiles; the heights derived from the modified wavelet algorithm and from visual inspection of the HSRL backscatter images agreed to within $10 \mathrm{~m}$ in $85 \%$ of the cases examined during the study. Entrainment zone thickness was derived as the distance between the 15 th and 85 th percentiles

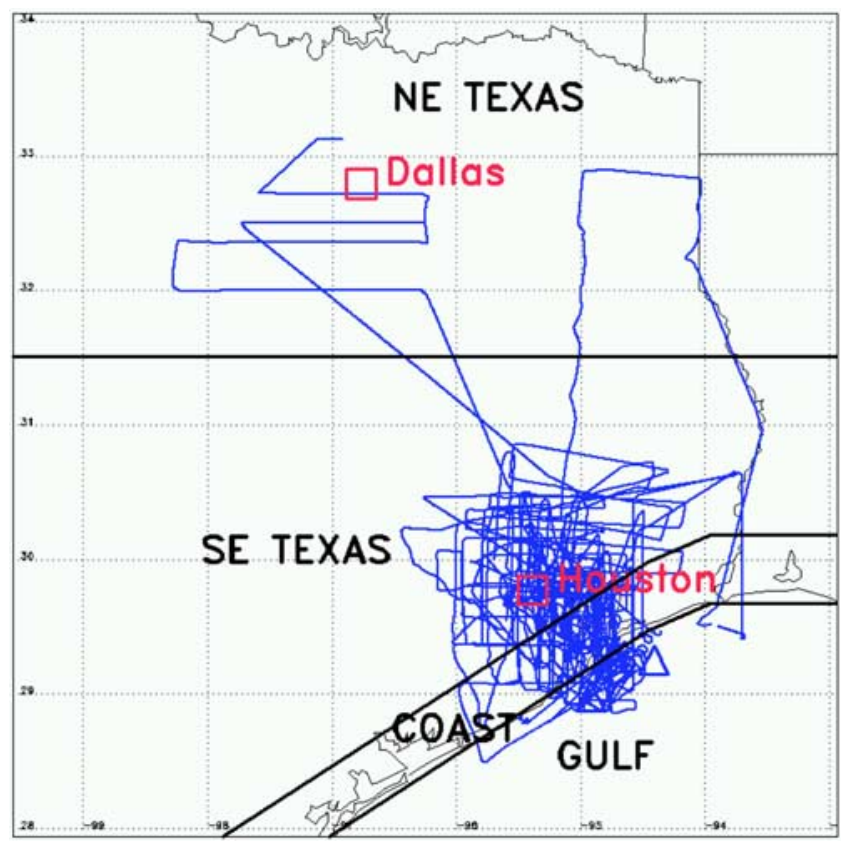

Figure A2. Composite of all NOAA Twin Otter flight tracks for which lidar data are reported during TexAQS 2006. Regions are designated for regional analysis of background ozone. 
Table A4. NOAA Research Vessel Ronald H. Brown Instrumentation

\begin{tabular}{|c|c|c|c|c|c|}
\hline Species/Parameter & Reference & Technique & Averaging Time & Detection Limit & Uncertainty \\
\hline $\mathrm{JNO}_{2}$ Photolysis rates & Shetter et al. [2003] & Filter radiometer & $1 \mathrm{~min}$ & $4.0 \times 10^{-6} \mathrm{~Hz}$ & $\pm 12 \%$ \\
\hline $\mathrm{JNO}_{3}$ Photolysis rates & Stark et al. [2007] & Filter radiometer & $1 \mathrm{~min}$ & $1.3 \times 10^{-5} \mathrm{~Hz}$ & $\pm 14 \%$ \\
\hline $\mathrm{JO}_{3}\left({ }^{1} \mathrm{D}\right)$ Photolysis rates & Bohn et al. [2004] & Filter radiometer & $1 \mathrm{~min}$ & $1.1 \times 10^{-7} \mathrm{~Hz}$ & $\pm 26 \%$ \\
\hline Ozone & Bates et al. [2005] & UV absorbance & $1 \mathrm{~min}$ & $1.0 \mathrm{ppbv}$ & $\pm 1.0 \mathrm{ppbv}$ or $2 \%$ \\
\hline Ozone & Williams et al. [2006] & NO chemiluminescence & $1 \mathrm{~min}$ & $0.1 \mathrm{ppbv}$ & $\pm 2 \%$ \\
\hline Ozone vertical profiles & Thompson et al. [2000] & Ozonesondes & $1 \mathrm{~s}(=5 \mathrm{~m})$ & 2 ppbv & $3-5 \%$ \\
\hline Ozone vertical profiles & Zhao et al. [1993] & $\mathrm{O}_{3}$ lidar (OPAL) & $10 \mathrm{~min}$ & $5 \mathrm{ppb}$ & $<10 \mathrm{ppb}$ \\
\hline Carbon monoxide & Gerbig et al. [1999] & UV fluorescence & $1 \mathrm{~min}$ & $1.5 \mathrm{ppbv}$ & $\pm 3.0 \%$ \\
\hline Carbon dioxide & LiCor spec & Nondispersive IR & $1 \mathrm{~min}$ & $<1 \mathrm{ppmv}$ & $0.08 \mathrm{ppmv}$ \\
\hline Water vapor & Calculated & $\mathrm{RH} /$ temperature probe & $1 \mathrm{~min}$ & $0.1 \mathrm{ppthv}$ & $\pm 5 \%$ \\
\hline Sulfur dioxide & Bates et al. [2005] & Pulsed fluorescence & $1 \mathrm{~min}$ & $0.1 \mathrm{ppbv}$ & $< \pm 5 \%$ \\
\hline Nitric oxide & Fehsenfeld et al. [1990] & Chemiluminescence & $1 \mathrm{~min}$ & $0.010 \mathrm{ppbv}$ & $\pm(3.8 \%+0.010 \mathrm{ppbv})$ \\
\hline Nitrogen dioxide & Ryerson et al. [2000] & Photolysis cell & $1 \mathrm{~min}$ & $0.060 \mathrm{ppbv}$ & $\begin{array}{c} \pm(13 \%+0.093 \text { ppbv }) \\
\text { (a) } \mathrm{NO} 2 / \mathrm{NO}=3\end{array}$ \\
\hline Total nitrogen oxides & Williams et al. [1998] & $\mathrm{Au}$ tube reduction & $1 \mathrm{~min}$ & $0.08 \mathrm{ppbv}$ & $\pm(15 \%+0.08 \mathrm{ppbv})$ \\
\hline PANs & Slusher et al. [2004] & TD/CIMS & $1 \mathrm{~min}$ & $\begin{array}{l}\text { PAN/PPN (2 pptv); } \\
\text { tPBN/APAN (4 pptv) }\end{array}$ & $\begin{array}{l}\text { PAN/PPN } \pm \\
\quad(2 \mathrm{pptv}+15 \%) \\
\text { tPBN/MPAN } \\
\pm(4 \text { pptv }+20 \%)\end{array}$ \\
\hline $\begin{array}{l}\text { Alkyl nitrates, } \\
\text { hydrocarbons }\end{array}$ & Goldan et al. [2004] & GC/FID/MS & $5 \mathrm{~min}$ & $\leq 1 \mathrm{pptv}$ & $\pm 20 \%$ \\
\hline $\begin{array}{l}\text { Continuous speciation } \\
\text { of VOCs }\end{array}$ & Warneke et al. [2005] & PIT-MS/CIMS & $1 \mathrm{~min}$ & $0.05-0.50 \mathrm{ppbv}$ & $20 \%$ \\
\hline $\mathrm{NO}_{3} / \mathrm{N}_{2} \mathrm{O}_{5}$ & Dubé et al. [2006] & $\begin{array}{l}\text { Cavity ring-down } \\
\text { spectroscopy }\end{array}$ & $1 \mathrm{~s}$ & $1 \mathrm{pptv}$ & 1 pptv, $\pm 30 \%$ \\
\hline $\mathrm{NO}_{2}$ & Osthoff et al. [2006] & $\begin{array}{l}\text { Cavity ring-down } \\
\text { spectroscopy }\end{array}$ & $1 \mathrm{~s}$ & $0.20 \mathrm{ppbv}$ & $0.20 \mathrm{ppbv}, \pm 8 \%$ \\
\hline $\begin{array}{l}\mathrm{HNO}_{3} / \text { soluble } \mathrm{NO}_{2}^{-} / \\
\text {soluble } \mathrm{Cl}^{-}\end{array}$ & Dibb et al. [2004] & $\begin{array}{l}\text { Automated mist } \\
\text { chamber/IC }\end{array}$ & $5 \mathrm{~min}$ & 5 pptv & $15 \%$ \\
\hline $\mathrm{HCHO} / \mathrm{HCOOH}$ & Herndon et al. [2007] & TILDAS & $1 \mathrm{~s}$ & $0.180 \mathrm{ppbv}$ & $10 \%$ \\
\hline $\mathrm{HO}_{2} / \mathrm{RO}_{2}$ & Green et al. [2006] & PERCA & $1 \mathrm{~min}$ & $2 \mathrm{pptv}$ & $40 \%$ \\
\hline $\mathrm{Hg}$ & Sholupov et al. [2004] & $\begin{array}{l}\text { Atomic absorption } \\
\text { spect. }\end{array}$ & $1 \mathrm{~s}$ & $<5 \mathrm{ng} \mathrm{m}^{-3}$ & $\pm(1.5-2.6) \mathrm{ng} \mathrm{m}^{-3}$ \\
\hline Radon & $\begin{array}{l}\text { Whittlestone and } \\
\text { Zahorowski [1998] }\end{array}$ & Radon gas decay & $13 \mathrm{~min}$ & & \\
\hline $\begin{array}{l}\text { Seawater and } \\
\text { atmospheric } \mathrm{pCO}_{2}\end{array}$ & Sabine et al. [2000] & Nondispersive IR & $30 \mathrm{~min}$ & & $\pm 0.2 \mathrm{ppm}$ \\
\hline Seawater DMS & Bates et al. [2000] & $\mathrm{S}$ chemiluminesence & $30 \mathrm{~min}$ & $0.2 \mathrm{nM}$ & $\pm 8 \%$ \\
\hline $\begin{array}{l}\text { Aerosol ionic } \\
\text { composition }\end{array}$ & Bates et al. [2008] & PILS-IC & $5 \min$ & $0.1 \mu \mathrm{g} \mathrm{m}^{-3}$ & $\pm 20 \%$ \\
\hline Aerosol WSOC & Bates et al. [2008] & PILS-TOC & $1 \mathrm{~min}$ & $0.1 \mu \mathrm{g} \mathrm{m}^{-3}$ & $\pm 17 \%$ \\
\hline $\begin{array}{l}\text { Aerosol size and } \\
\text { composition }\end{array}$ & Bates et al. [2008] & Q-AMS & $5 \mathrm{~min}$ & $0.1 \mu \mathrm{g} \mathrm{m}^{-3}$ & $\pm 20 \%$ \\
\hline $\begin{array}{l}\text { Aerosol size and } \\
\text { composition }\end{array}$ & DeCarlo et al. [2006] & HR-TOF-AMS & $1-10 \mathrm{~s}$ & $0.05 \mu \mathrm{g} \mathrm{m}^{-3}$ & $\pm 20 \%$ \\
\hline Aerosol OC & Bates et al. [2008] & Online thermal/optical & $45 \mathrm{~min}$ & $0.1 \mu \mathrm{g} \mathrm{m}^{-3}$ & $\pm 21 \%$ \\
\hline $\begin{array}{l}\text { Aerosol organic } \\
\text { functional groups }\end{array}$ & Gilardoni et al. [2007] & $\begin{array}{l}\text { FTIR spectroscopy } \\
\text { of }<1 \mu \mathrm{m} \text { particles on } \\
\text { Teflon filters }\end{array}$ & $4-12 \mathrm{~h}$ & $1 \mu \mathrm{g}$ & $\pm 15 \%$ \\
\hline $\begin{array}{l}\text { Aerosol organic } \\
\text { speciation }\end{array}$ & Thornberry et al. [2009] & $\begin{array}{l}\text { Collection/thermal } \\
\text { desorption/PTR-MS }\end{array}$ & $10 \mathrm{~min}$ & $0.02 \mu \mathrm{g} \mathrm{m}^{-3}$ & \\
\hline $\begin{array}{l}\text { Aerosol composition, } \\
2 \text { stage (sub/super } \\
\text { micron) and } 7 \text { stage } \\
\text { at } 60 \% \mathrm{RH}\end{array}$ & Bates et al. [2008] & $\begin{array}{l}\text { Impactors (IC, XRF and } \\
\text { thermal optical OC/EC, } \\
\text { total gravimetric } \\
\text { weight) }\end{array}$ & $4-12 \mathrm{~h}$ & & $\pm 6-31 \%$ \\
\hline $\begin{array}{l}\text { Total and submicron } \\
\text { aerosol scattering } \\
\text { and backscattering } \\
(450,550,700 \mathrm{~nm}) \\
\text { at } 60 \% \mathrm{RH}\end{array}$ & Quinn and Bates [2005] & $\begin{array}{l}\text { TSI } 3563 \\
\text { nephelometers (2) }\end{array}$ & $1 \mathrm{~min}$ & & $\pm 14 \%$ \\
\hline $\begin{array}{l}\text { Total and submicron } \\
\text { aerosol light scattering } \\
\text { hygroscopic growth }\end{array}$ & Carrico et al. [2003] & $\begin{array}{l}\text { Twin TSI } 3563 \\
\text { nephelometers RR } \\
\text { M903 nephelometer }\end{array}$ & $\begin{array}{c}20 \mathrm{~s} \text { (over each } \\
1 \% \mathrm{RH})\end{array}$ & $\begin{array}{l}\sigma_{\text {spTSI }}: 1.85 \text { and } \\
2.78 \sigma_{\text {bsp }}: 1.24 \text { and } \\
2.96 \sigma_{\text {spRR }}: 1.06\end{array}$ & $\begin{array}{l}\sigma_{\text {spTSI }}:-14 \sim \\
17 \sigma_{\text {bsp }}: \\
\quad-17 \sim 19\end{array}$ \\
\hline $\begin{array}{l}\text { Total and submicron } \\
\text { aerosol absorption } \\
(450,550,700 \mathrm{~nm}) \text { dry }\end{array}$ & Sierau et al. [2006] & $\begin{array}{l}\text { Radiance Research } \\
\text { PSAPs (2) }\end{array}$ & $1 \mathrm{~min}$ & & $\pm 22 \%$ \\
\hline $\begin{array}{l}\text { Submicrometer aerosol } \\
\text { absorption } \\
\text { (532 nm) dry }\end{array}$ & Lack et al. [2006] & $\begin{array}{l}\text { Photoacoustic Aerosol } \\
\text { Absorption } \\
\text { Spectrometer }\end{array}$ & $1 \mathrm{~min}$ & $0.1 \mathrm{M} \mathrm{m}^{-1}$ & $\pm 5 \%$ \\
\hline $\begin{array}{l}\text { Total and submicron } \\
\text { aerosol extinction }\end{array}$ & Baynard et al. [2007] & $\begin{array}{l}\text { Cavity ring-down } \\
\text { spectroscopy }\end{array}$ & $1 \mathrm{~min}$ & $0.01 \mathrm{M} \mathrm{m}^{-1}$ & $\pm 1 \%$ \\
\hline
\end{tabular}


Table A4. (continued)

\begin{tabular}{|c|c|c|c|c|c|}
\hline Species/Parameter & Reference & Technique & Averaging Time & Detection Limit & Uncertainty \\
\hline $\begin{array}{l}\text { Total and submicron } \\
\text { aerosol light extinction } \\
\text { hygroscopic growth }\end{array}$ & Massoli et al. [2009] & $\begin{array}{l}\text { Cavity ring-down } \\
\text { spectroscopy }\end{array}$ & $1 \mathrm{~min}$ & $0.01 \mathrm{M} \mathrm{m}^{-1}$ & $\pm 5 \%$ \\
\hline Aerosol number & Bates et al. [2001] & CNC (TSI 3010, 3025) & $1 \mathrm{~s}$ & & $\pm 10 \%$ \\
\hline Aerosol size distribution & Bates et al. [2005] & DMA and APS & $5 \mathrm{~min}$ & & $\pm 10 \%$ \\
\hline Cloud condensation nuclei & Quinn et al. [2008] & DMT CCN counter & $30 \mathrm{~min}$ & & $\pm 10 \%$ \\
\hline Aerosol optical depth & Quinn and Bates [2005] & Microtops & intermittent & & $\pm 0.015 \mathrm{AOD}$ \\
\hline $\begin{array}{l}\text { Aerosol backscatter } \\
\text { vertical profiles }\end{array}$ & Zhao et al. [1993] & $\mathrm{O}_{3}$ lidar (OPAL) & $10 \min$ & $1 * 10^{-6} \mathrm{~m}^{-1} \mathrm{sr}^{-1}$ & $\begin{array}{l}30 \% \text { aerosol } \\
\text { backscatter }\end{array}$ \\
\hline $\begin{array}{l}\text { BL wind/aerosol/ } \\
\text { turbulence }\end{array}$ & Grund et al. [2001] & Doppler lidar (HRDL) & $0.5 \mathrm{~s}$ & $2-6 \mathrm{~km}$ & $10-12 \mathrm{~cm} \mathrm{~s}^{-1}$ \\
\hline $\begin{array}{l}\text { Wind/temperature } \\
\text { profiles }\end{array}$ & Law et al. [2002] & 915-MHz wind profiler & $5 \mathrm{~min}$ & $0.5-5 \mathrm{~km}$ & $\pm 1.4 \mathrm{~m} \mathrm{~s}^{-1}$ \\
\hline $\begin{array}{l}\text { Temperature/RH } \\
\text { profiles }\end{array}$ & Wolfe et al. [2007] & Sondes & $5 \mathrm{~s}$ & $0.1-18 \mathrm{~km}$ & $\pm 0.3^{\circ} \mathrm{C} \pm 4 \%$ \\
\hline Radiative fluxes & Pilewskie et al. [2003] & Spectroradiometers & $1 \mathrm{~Hz}$ & & $3-5 \%$ \\
\hline Cloud height & Fairall et al. [1997] & Ceilometer & $15 \mathrm{~s}$ & $0.1-7.5 \mathrm{~km}$ & $\pm 30 \mathrm{~m}$ \\
\hline $\begin{array}{l}\text { Cloud drop size, } \\
\text { updraft velocity }\end{array}$ & Kollias et al. [2001] & 3-mm Doppler radar & $5 \mathrm{~s}$ & $0.2-12 \mathrm{~km}$ & - \\
\hline Turbulent fluxes & Fairall et al. [2003, 2006] & $\begin{array}{l}\text { Bow-mounted EC flux } \\
\text { package }\end{array}$ & $\begin{array}{l}20 \mathrm{~Hz} \\
10 \mathrm{~min}, 1 \mathrm{~h}\end{array}$ & $\begin{array}{l}2 \mathrm{~W} \mathrm{~m}^{-2} \\
0.002 \mathrm{~N} \mathrm{~m}^{-2}\end{array}$ & $\pm 25 \%$ at $1 \mathrm{~h}$ \\
\hline $\begin{array}{l}\text { Low-altitude } \\
\text { temperature profiles }\end{array}$ & Cimini et al. [2003] & $\begin{array}{l}\text { 60-GHz scanning } \\
\text { microwave radiometer }\end{array}$ & $10 \mathrm{~s}$ & $0-0.5 \mathrm{~km}$ & $\pm 0.3^{\circ} \mathrm{C}$ \\
\hline $\begin{array}{l}\text { Wind profiles/ } \\
\text { microturbulence } \\
\text { below cloud }\end{array}$ & $\begin{array}{l}\text { Frisch et al. }[1989] \\
\quad \text { Comstock et al. }[2005]\end{array}$ & $\mathrm{C}$ band radar & $5 \mathrm{~min}$ & $0.1-2 \mathrm{~km}$ & $\pm 1.0 \mathrm{~m} \mathrm{~s}^{-1}$ \\
\hline
\end{tabular}

Table A5. CIRPAS Twin Otter Aircraft Instrumentation for Aerosol and Ancillary Data Measurements

\begin{tabular}{|c|c|c|c|c|c|}
\hline Parameter & Reference & Technique & $\begin{array}{l}\text { Averaging } \\
\text { Time }\end{array}$ & Detection Limit & $\begin{array}{l}\text { Size Range } \\
\text { Detected }\end{array}$ \\
\hline $\begin{array}{r}\text { Particle number } \\
\text { concentration }\end{array}$ & $\begin{array}{l}\text { Mertes et al. }[1995] \\
\text { and Buzorius [2001] }\end{array}$ & $\begin{array}{l}\text { condensation particle } \\
\text { counter (TSI CPC 3010) }\end{array}$ & $1 \mathrm{~s}$ & $0-10,000$ particles $/ \mathrm{cm}^{3}$ & $\mathrm{D}_{\mathrm{p}}>10 \mathrm{~nm}$ \\
\hline $\begin{array}{l}\text { Cloud condensation } \\
\text { nuclei concentration }\end{array}$ & $\begin{array}{l}\text { Roberts and Nenes } \\
{[2005] \text { Lance et al. }} \\
\text { [2006] }\end{array}$ & $\begin{array}{l}\text { continuous flow streamwise } \\
\text { thermal gradient CCN } \\
\text { counter (DMT) }\end{array}$ & $1 \mathrm{~s}$ & $0-10,000$ particles $/ \mathrm{cm}^{3}$ & $\mathrm{~N} / \mathrm{A}$ \\
\hline $\begin{array}{l}\text { Aerosol size } \\
\text { distributions at } \\
\text { dry and humid } \\
\text { condition }\end{array}$ & $\begin{array}{l}\text { Wang and Flagan [1990] } \\
\text { and Wang et al. }[2003]\end{array}$ & $\begin{array}{l}\text { scanning differential mobility } \\
\text { analyzer (dual automated } \\
\text { classified aerosol detector } \\
\text { (DACAD)) }\end{array}$ & $73 \mathrm{~s}$ & N/A & $10-700 \mathrm{~nm}$ \\
\hline $\begin{array}{l}\text { Aerosol size } \\
\text { distribution }\end{array}$ & & $\begin{array}{l}\text { passive cavity aerosol } \\
\text { spectrometer (PCASP) }\end{array}$ & $1 \mathrm{~s}$ & N/A & $0.1-2.6 \mu \mathrm{m}$ \\
\hline $\begin{array}{l}\text { Aerosol bulk ionic } \\
\text { composition and } \\
\text { soluble organic } \\
\text { composition }\end{array}$ & $\begin{array}{l}\text { Weber et al. [2001] and } \\
\text { Sorooshian et al. }[2006]\end{array}$ & $\begin{array}{l}\text { particle-into-liquid sampler } \\
\text { (PILS) }\end{array}$ & $5 \mathrm{~m}$ & $\begin{array}{l}0.02-0.28 \mu \mathrm{g} / \mathrm{m}^{3} \\
\quad \text { (depending on species) }\end{array}$ & $<1 \mu \mathrm{m}$ \\
\hline $\begin{array}{l}\text { Aerosol bulk } \\
\text { composition } \\
\text { (nonrefractory } \\
\text { species) }\end{array}$ & $\begin{array}{l}\text { Jayne et al. [2000] and } \\
\text { Bahreini et al. [2003] }\end{array}$ & $\begin{array}{l}\text { Aerodyne quadrupole aerosol } \\
\text { mass spectrometer (AMS) }\end{array}$ & $30 \mathrm{~s}$ or $1 \mathrm{~m}$ & $\begin{array}{l}0.02-2.3 \mu \mathrm{g} / \mathrm{m}^{3} \\
\quad \text { (depending on species) }\end{array}$ & $\begin{array}{l}\mathrm{D}_{\mathrm{va}} \sim 40 \mathrm{~nm} \\
\quad \text { to } 1 \mu \mathrm{m}\end{array}$ \\
\hline Soot absorption & Arnott et al. $[1999,2006]$ & $\begin{array}{l}\text { photoacoustic absorption } \\
\text { spectrometer }\end{array}$ & $1 \mathrm{~s}$ & $1 \mathrm{M} \mathrm{m}^{-1}$ & $10 \mathrm{~nm}$ to $5 \mu \mathrm{m}$ \\
\hline Soot absorption & Bond et al. [1999] & $\begin{array}{l}\text { particle soot absorption } \\
\text { photometer (PSAP) }\end{array}$ & $1 \mathrm{~s}$ or higher & N/A & N/A \\
\hline Soot absorption & $\begin{array}{l}\text { Baumgardner et al. [2004] } \\
\text { Schwarz et al. }[2008]\end{array}$ & $\begin{array}{l}\text { single particle soot photometer } \\
\text { (SP2) (DMT) }\end{array}$ & N/A & N/A & $\begin{array}{l}150 \mathrm{~nm} \\
\text { to } 1.5 \mu \mathrm{m}\end{array}$ \\
\hline $\begin{array}{l}\text { Separation of cloud } \\
\text { droplets from } \\
\text { interstitial aerosol }\end{array}$ & $\begin{array}{l}\text { Noone et al. }[1988] \\
\text { Ogren et al. }[1992]\end{array}$ & counterflow virtual impactor & N/A & N/A & N/A \\
\hline $\begin{array}{l}\text { Cloud and precipitation } \\
\text { size distribution }\end{array}$ & Baumgardner et al. [2001] & $\begin{array}{l}\text { Cloud, aerosol, and precipitation } \\
\text { spectrometer (CAPS) }\end{array}$ & $1 \mathrm{~s}$ & $0-1,000$ particles $/ \mathrm{cm}^{-3}$ & $\begin{array}{r}0.4 \mu \mathrm{m} \text { to } \\
1.6 \mathrm{~mm}\end{array}$ \\
\hline $\begin{array}{l}\text { Cloud droplet size } \\
\text { distribution }\end{array}$ & Cerni [1983] & $\begin{array}{l}\text { forward scattering spectrometer } \\
\text { probe (FSSP) }\end{array}$ & $1 \mathrm{~s}$ & N/A & $1-46 \mu \mathrm{m}$ \\
\hline $\begin{array}{l}\text { Cloud droplet liquid } \\
\text { water content }\end{array}$ & Gerber et al. [1994] & $\begin{array}{l}\text { light diffraction } \\
\text { (Gerber PVM-100 probe) }\end{array}$ & $1 \mathrm{~s}$ & N/A & $\sim 5-50 \mu \mathrm{m}$ \\
\hline Drop size distribution & Chuang et al. [2008] & Phase-Doppler Interferometer & $0.1-1 \mathrm{~s}$ & $\mathrm{~N} / \mathrm{A}$ & $\sim 2-150 \mu \mathrm{m}$ \\
\hline
\end{tabular}


Table A6. CIRPAS Twin Otter Flights

\begin{tabular}{clc}
\hline $\begin{array}{c}\text { Flight } \\
\text { Number }\end{array}$ & \multicolumn{1}{c}{$\begin{array}{c}\text { Flight } \\
\text { Description }\end{array}$} & $\begin{array}{c}\text { Date in } \\
2006\end{array}$ \\
\hline 1 & Parish power plant plume & 21 Aug \\
2 & Parish power plant plume & 22 Aug \\
3 & Parish power plant plume & 23 Aug \\
4 & Houston Ship Channel area & 25 Aug \\
5 & Conroe area & 26 Aug \\
6 & Beaumont area & 27 Aug \\
7 & Baytown area & 28 Aug \\
8 & Baytown area & 28 Aug \\
9 & Parish power plant plume & 29 Aug \\
10 & Houston Ship Channel area & 31 Aug \\
11 & Houston Ship Channel area & $1 \mathrm{Sep}$ \\
12 & Biomass burning & $2 \mathrm{Sep}$ \\
13 & Houston area & $3 \mathrm{Sep}$ \\
14 & Parish power plant plume & $4 \mathrm{Sep}$ \\
15 & Waste treatment plant area & $6 \mathrm{Sep}$ \\
16 & Galveston area & $7 \mathrm{Sep}$ \\
17 & Parish power plant plume & $8 \mathrm{Sep}$ \\
18 & Houston area & $10 \mathrm{Sep}$ \\
19 & Fayetteville power plant plume & $11 \mathrm{Sep}$ \\
20 & Conroe area & $13 \mathrm{Sep}$ \\
21 & Houston area & $14 \mathrm{Sep}$ \\
22 & Houston area & $15 \mathrm{Sep}$ \\
\hline
\end{tabular}

of the lidar-derived boundary layer heights as per Cohn and Angevine [2000].

[87] A wide variety of satellite-borne instrumentation was integrated into the analysis conducted during TexAQS II/ GoMACCS. This analysis included both providing evaluations of the satellite data themselves through comparisons with simultaneously collected in situ data, and including those data in scientific analyses. Section 3.4 summarizes some of this analysis. Table A8 summarizes the characteristics of the satellite instrumentation.

[88] The 22-site Intercontinental Transport Experiment (INTEX) Ozonesonde Network Study (IONS-06) launched sondes during July through September, 2006. Table A9 summarizes the launches. Ozone was determined with electrochemical concentration cells; standard radiosondes, usually RS-80 or RS-92 Vaisala instruments, collected pressure-temperature and below $100 \mathrm{hPa}$, relative humidity, at $5-10 \mathrm{~m}$ resolution. The ozonesondes cover surface to $10 \mathrm{hPa}$ or above with 50 - to $100-\mathrm{m}$ resolution in ozone partial pressure; all profiles are archived at http://croc.gsfc. nasa.gov/intexb/ions06.html.

\section{Appendix B: Surface Site Networks}

[89] Figure B1 shows the location of sites in the Surface Air Quality Monitoring Network for the TexAQS II campaign, and Table B1 summarizes the measurements conducted at sixteen sites specifically added to the surface site network for TexAQS II. These sites measure a variety of air pollutant concentrations and the data are archived at http:// www.tceq.state.tx.us/compliance/monitoring/air/monops/ hourly data.html.

[90] The Radar Wind Profiler Network comprised 10 landbased, one oil platform-based, and one shipboard $915-\mathrm{MHz}$ Doppler radar wind profilers [Carter et al., 1995] that measured winds in the planetary boundary layer (see Figure B2 and Table B2). Typical vertical coverage was from $120 \mathrm{~m}$ to $\sim 4000 \mathrm{~m}$ above the surface, depending on atmospheric conditions. Radio acoustic sounding systems (RASS) were operated in conjunction with most of the wind profilers to measure temperature profiles up to $\sim 1500 \mathrm{~m}$. The vertical resolutions of both the wind and temperature measurements were either $60 \mathrm{~m}$ or $100 \mathrm{~m}$. The wind profiler data were quality controlled after the data collection period using the continuity technique developed by Weber et al. [1993].

[91] Operation of the wind profiler on the R/V Ronald $H$. Brown was hindered by sea clutter (i.e., sidelobe reflections from the ocean surface), which often prevented wind retrievals

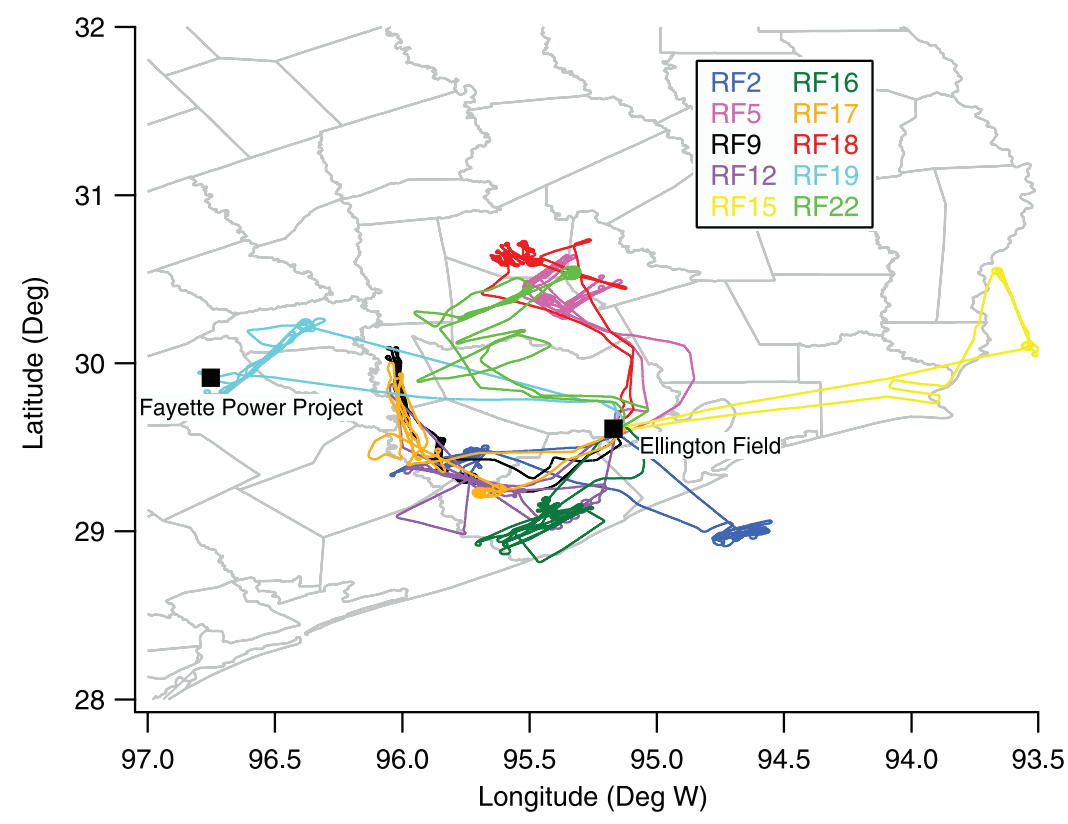

Figure A3. Flight paths of the CIRPAS Twin Otter flights during GoMACCS. These are the 10 flights that intercepted clouds most appropriate for study. 
Table A7. NASA B200 King Air Flights ${ }^{\mathrm{a}}$

\begin{tabular}{|c|c|c|c|c|c|c|c|c|c|c|c|c|c|}
\hline \multirow[b]{2}{*}{ Date } & \multirow[b]{2}{*}{$\begin{array}{c}\text { Flight } \\
\text { Number }\end{array}$} & \multirow{2}{*}{$\begin{array}{l}\text { Begin } \\
\text { Time } \\
\text { (UT) }\end{array}$} & \multirow{2}{*}{$\begin{array}{l}\text { End } \\
\text { Time } \\
\text { (UT) }\end{array}$} & \multicolumn{9}{|c|}{ Coordination } & \multirow[b]{2}{*}{ Comments } \\
\hline & & & & $\begin{array}{l}\text { Moody } \\
\text { Tower }\end{array}$ & RHB & P3 & NTO & $\mathrm{CTO}$ & CALIPSO & $\begin{array}{l}\text { MODIS } \\
\text { (Aqua) }\end{array}$ & $\begin{array}{c}\text { MODIS } \\
(\text { Terra })\end{array}$ & MISR & \\
\hline \multirow[t]{2}{*}{27 Aug } & 1 & 1701 & 1911 & & & & & & & & & & $\begin{array}{l}\text { Transit flight from NASA } \\
\text { Langley to Houston }\end{array}$ \\
\hline & 2 & 2021 & 2152 & & & & & & & & & & $\begin{array}{l}\text { Transit flight from NASA } \\
\text { Langley to Houston }\end{array}$ \\
\hline 28 Aug & 3 & 1841 & 2013 & & & & G & G & G D & G W & & & $\begin{array}{l}\text { CALIPSO validation flight. } \\
\text { Observed Saharan dust. }\end{array}$ \\
\hline 29 Aug & 4 & 1501 & 1819 & G & $\mathbf{M}$ & & & M & & & L W & M & Raster scan of Houston \\
\hline 31 Aug & 5 & 1606 & 1839 & G & & & M & M & & & G L W & G & $\begin{array}{l}\text { Raster scan of Houston area } \\
\text { and MISR local mode. }\end{array}$ \\
\hline 3 Sep & 6 & 1519 & 1827 & & & & M & & & & M L W & & $\begin{array}{l}\text { Flight over Gulf; highest } \\
\text { observed aerosol optical } \\
\text { thickness }\end{array}$ \\
\hline 4 Sep & 7 & 1811 & 2127 & G & G & & & G & G D & G L W & & & CALIPSO validation flight \\
\hline $6 \mathrm{Sep}$ & 8 & 1831 & 2139 & & & & & G & G D & G L W & & & $\begin{array}{l}\text { CALIPSO validation flight } \\
\text { east of Houston }\end{array}$ \\
\hline $7 \mathrm{Sep}$ & 9 & 1602 & 1924 & G & & & G & & & & G L W & G & $\begin{array}{l}\text { Raster scan over Houston and } \\
\text { MISR local mode box }\end{array}$ \\
\hline $8 \mathrm{Sep}$ & 10 & 1602 & 1924 & & & & M & & & & & & $\begin{array}{l}\text { Coordinated NTO track on } \\
\text { LA-TX border and Dallas }\end{array}$ \\
\hline $13 \mathrm{Sep}$ & 11 & 1837 & 2149 & & & G & G & & G D & G L & & & $\begin{array}{l}\text { CALIPSO validation track to } \\
\text { Dallas and scan of Dallas }\end{array}$ \\
\hline 14 Sep & 12 & 1633 & 1852 & G & & & & M & & & & M & $\begin{array}{l}\text { Raster scan of Houston and } \\
\text { MISR local mode box }\end{array}$ \\
\hline 15 Sep & 13 & 1700 & 2024 & M & & M & & M & & & & & $\begin{array}{l}\text { Tight raster pattern over } \\
\text { Houston }\end{array}$ \\
\hline \multirow[t]{2}{*}{17 Sep } & 14 & 0642 & 0931 & & & & & & G N & & & & $\begin{array}{l}\text { Night CALIPSO flight over } \\
\text { Arizona and Louisiana }\end{array}$ \\
\hline & 15 & 1055 & 1334 & & & & & & G N & & & & $\begin{array}{l}\text { Night CALIPSO flight over } \\
\text { Arizona and Louisiana }\end{array}$ \\
\hline 19 Sep & 16 & 1654 & 2038 & G & & G & & & & & & & Raster scan of Houston \\
\hline 20 Sep & 17 & 1750 & 2136 & & & $\mathbf{M}$ & & & G D & G L W & & & $\begin{array}{l}\text { CALIPSO validation flight } \\
\text { west of Houston to Dallas }\end{array}$ \\
\hline 21 Sep & 18 & 1723 & 2038 & & & G & & & & & & & $\begin{array}{l}\text { Raster pattern over Houston } \\
\text { coordinated with P3 }\end{array}$ \\
\hline 22 Sep & 19 & 1755 & 2139 & & & & & & G D & G L & & & $\begin{array}{l}\text { CALIPSO validation flight to } \\
\text { Lincoln, Nebraska }\end{array}$ \\
\hline 24 Sep & 20 & 0637 & 0937 & & & & & & G N & & & & $\begin{array}{l}\text { CALIPSO validation flight and } \\
\text { return to Houston }\end{array}$ \\
\hline 25 Sep & 21 & 1954 & 2242 & G & & G & & & & $\mathbf{M}$ & & & $\begin{array}{l}\text { Raster pattern over Houston } \\
\text { coordinated with P3 }\end{array}$ \\
\hline 26 Sep & 22 & 1805 & 2120 & & & G & & & & M & & & $\begin{array}{l}\text { Raster pattern over Houston } \\
\text { coordinated with P3 }\end{array}$ \\
\hline 27 Sep & 23 & 1657 & 2059 & & & & & & G D & M & & & $\begin{array}{l}\text { CALIPSO validation flight } \\
\text { west of Dallas }\end{array}$ \\
\hline \multirow[t]{2}{*}{28 Sep } & 24 & 1445 & 1608 & & & & & & G D & M & & & $\begin{array}{l}\text { Transit flight to NASA Langley } \\
\text { with CALIPSO track en route }\end{array}$ \\
\hline & 25 & 1739 & 2039 & & & & & & G D & $\mathbf{M}$ & & & $\begin{array}{l}\text { Transit flight to NASA Langley } \\
\text { with CALIPSO track en route }\end{array}$ \\
\hline
\end{tabular}

${ }^{a}$ The boldface letters indicate that a comparison/validation/coordination was conducted: G denotes good degree of success; M denotes moderate or questionable degree of success. CALIPSO validation flights are indicated as day (D) or night (N); MODIS coincidences are indicated as over land (L) or water (W). Platform Abbreviations: RHB, Ronald H. Brown; P3, NOAA WP-3D; NTO, NOAA Twin Otter; CTO, CIRPAS Twin Otter. 


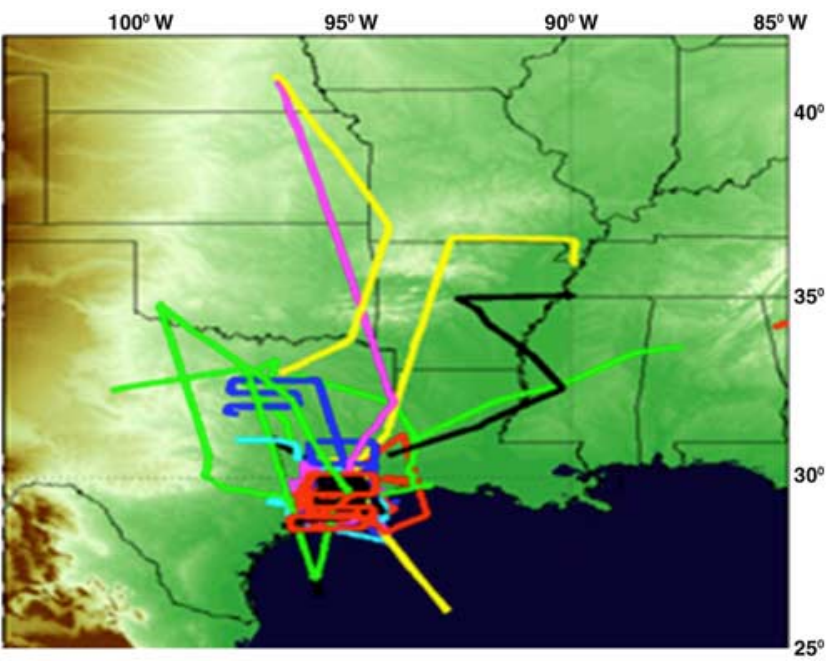

Figure A4. Flight tracks of the NASA B200 King Air during TexAQS/GoMACCS. The terrain elevation is qualitatively indicated by the background color.

in approximately the lowest $500 \mathrm{~m}$ above the surface. A Doppler lidar on the Ronald H. Brown measured winds below clouds with up to $5 \mathrm{~m}$ resolution using the velocity-azimuth display (VAD) technique [Browning and Wexler, 1968].

[92] During TexAQS II, NOAA maintained an Internetbased air mass trajectory tool [White et al., 2006] that used
Table A9. IONS-06 Ozone Sonde Stations in Summer 2006

\begin{tabular}{|c|c|c|}
\hline Station & $\begin{array}{l}\text { Latitude, } \\
\text { Longitude }\end{array}$ & $\begin{array}{c}\text { Summer Period } \\
\text { (Number Launched) }\end{array}$ \\
\hline Barbados & $13.2,-59.5$ & $19 \mathrm{Jul}$ to $30 \mathrm{Aug}(27)$ \\
\hline Beltsville, $\mathrm{Md}^{\mathrm{a}}$ & $39.0,-76.5$ & $1-28$ Aug (12) \\
\hline Boulder, Colo. & $40.3,-105.2$ & $14 \mathrm{Jul}$ to $31 \mathrm{Aug}$ (34) \\
\hline Bratt's Lake, Sask. & $50.2,-104.7$ & $1-30$ Aug (29) \\
\hline Egbert, Ont. $^{\mathrm{a}}$ & $44.2,-79.8$ & $1-30$ Aug (15) \\
\hline Holtville, Calif. & $32.8,-115.4$ & $7-31$ Aug (13) \\
\hline Houston, Tex. ${ }^{\mathrm{a}}$ & $29.7,-95.4$ & 1-31 Aug (19) \\
\hline Huntsville, Ala. ${ }^{\text {a }}$ & $35.3,-86.6$ & 1 Aug to $2 \operatorname{Sep}(30)$ \\
\hline Kelowna, B. C. & $49.9,-119.4$ & $2-30$ Aug (27) \\
\hline Narragansett, R. I. ${ }^{\mathrm{a}}$ & $41.5,-71.4$ & $18 \mathrm{Jul}$ to $30 \mathrm{Aug}(30)$ \\
\hline Paradox, N. Y. & $43.9,-73.6$ & 30 Jun to 30 Aug (8) \\
\hline R/V Ronald H. Brown & Gulf of Mex. & $31 \mathrm{Jul}$ to $11 \mathrm{Sep}(35)$ \\
\hline Sable Is, N. S. ${ }^{\text {a }}$ & $44.0,-60.0$ & $1-31$ Aug (28) \\
\hline Socorro, N. M. & $36.4,-106.9$ & 1 Aug to 9 Sep (26) \\
\hline Stonyplain, Alberta & $53.6,-114.1$ & $9-30$ Aug (4) \\
\hline Trinidad Head, Calif. ${ }^{\text {a }}$ & $40.8,-124.2$ & $27 \mathrm{Jul}$ to 31 Aug (31) \\
\hline Table Mountain, Calif. & $34.4,-117.7$ & $1-31$ Aug (30) \\
\hline Mexico City & $19.4,-98.6$ & $22 \mathrm{Aug}$ to $20 \mathrm{Sep}(22$ \\
\hline Valparaiso, Indiana & $41.5,-87.0$ & $2-31$ Aug (5) \\
\hline Wallops Is, Va. $^{\text {a }}$ & $37.9,-75.5$ & 2-30 Aug (11) \\
\hline Walsingham, Ont. & $42.6,-80.6$ & $14-25$ Aug (22) \\
\hline Yarmouth, N. S. $^{\text {a }}$ & $43.9,-66.1$ & $2-30$ Aug (13) \\
\hline
\end{tabular}

${ }^{a}$ Site also participated in IONS-04 [Thompson et al., 2007].

real-time observations from the profiler network to calculate forward or backward trajectories. The NOAA wind profiler trajectory tool user interface is available at http://www.etl. noaa.gov/programs/2006/texaqs/traj/. The trajectory tool was used during the study to assist with mission planning

Table A8. NOAA and NASA Satellites and Their Measurement Capabilities

\begin{tabular}{|c|c|c|c|}
\hline Satellite Platform: Web Site & Relevant Instruments & Relevant Data Products & Vertical Resolution \\
\hline \multirow[t]{4}{*}{ NASA Aura: http://aura.gsfc.nasa.gov } & \multirow[t]{4}{*}{ HIRDLS MLS TES ${ }^{\mathrm{a}}$ OMI $^{\mathrm{b}}$} & $\mathrm{O}_{3}, \mathrm{HNO}_{3}$, and aerosol extinction & 1.25 km (UT/LS profiles) \\
\hline & & $\begin{array}{c}\mathrm{O}_{3}, \mathrm{CO}, \mathrm{ClO}, \mathrm{BrO}, \mathrm{HCl}, \mathrm{OH}, \mathrm{HO}_{2} \\
\mathrm{HNO}_{3}, \mathrm{HCN} \text {, and } \mathrm{N}_{2} \mathrm{O}\end{array}$ & $1.5-3 \mathrm{~km}$ (UT/LS profiles) \\
\hline & & $\mathrm{O}_{3}, \mathrm{CO}, \mathrm{CH}_{4}$ & $6 \mathrm{~km}$ (tropospheric profiles) \\
\hline & & $\begin{array}{l}\mathrm{O}_{3}, \mathrm{NO}_{2}, \mathrm{SO}_{2}, \mathrm{HCHO}, \mathrm{BrO}, \mathrm{OClO}, \\
\text { and aerosol characteristics }\end{array}$ & column \\
\hline \multirow[t]{3}{*}{ NASA Aqua: http://aqua.nasa.gov } & \multirow[t]{3}{*}{ MODIS $^{\mathrm{b}}$ AIRS $^{\mathrm{a}}$ CERES } & $\begin{array}{l}\text { aerosol optical depth, fine mode } \\
\text { fraction, fire detection }\end{array}$ & column, surface \\
\hline & & $\mathrm{O}_{3}, \mathrm{CO}, \mathrm{T}, \mathrm{Q}$ & $6 \mathrm{~km}$ (UT/LS Profiles) \\
\hline & & $\begin{array}{l}\text { solar, terrestrial, and total TOA } \\
\text { radiation and fluxes }\end{array}$ & TOA, Surface \\
\hline \multirow[t]{2}{*}{ NASA Terra: http://terra.nasa.gov } & \multirow[t]{2}{*}{ MOPITT MISR MODIS ${ }^{b}$} & $\begin{array}{l}\text { CO } \\
\text { aerosol optical depth, composition, } \\
\quad \text { size }\end{array}$ & $\begin{array}{l}6 \mathrm{~km} \text { (tropospheric profiles) } \\
\text { column }\end{array}$ \\
\hline & & $\begin{array}{l}\text { aerosol optical depth, fine mode } \\
\text { fraction, fire detection }\end{array}$ & column, surface \\
\hline $\begin{array}{l}\text { NASA CALIPSO: } \\
\text { http://www-calipso.larc.nasa.gov/ }\end{array}$ & CALIOP $^{\mathrm{a}}$ & $\begin{array}{l}\text { aerosol backscatter ratio, extinction, } \\
\text { height }\end{array}$ & $\begin{array}{l}120 \mathrm{~m}(Z<20 \mathrm{~km}) 360 \mathrm{~m} \\
\quad(Z>20 \mathrm{~km})\end{array}$ \\
\hline \multirow{3}{*}{$\begin{array}{l}\text { NOAA GOES-12: } \\
\text { http://www.oso.noaa.gov/goes/ }\end{array}$} & \multirow[t]{3}{*}{ Geostationary Imager } & Visible imagery & column \\
\hline & & $\begin{array}{l}\text { GOES Aerosol/Smoke Product (GASP) } \\
\text { Aerosol optical depth }\end{array}$ & column \\
\hline & & $\begin{array}{l}\text { Wildfire Automated Biomass Burning } \\
\text { Algorithm (WF-ABBA) }\end{array}$ & surface \\
\hline \multirow{7}{*}{$\begin{array}{l}\text { NOAA POES: } \\
\text { http://www.oso.noaa.gov/poes/ }\end{array}$} & \multirow[t]{7}{*}{ AVHRR TOVS SBUV/2 } & aerosol optical depth & column (ocean only) \\
\hline & & land cover & surface \\
\hline & & atmospheric temp & 15 layers (sfc- 0.4 mbar) \\
\hline & & precipitable water & 3 trop layers \\
\hline & & clouds & column \\
\hline & & precipitation, soil moisture & surface \\
\hline & & $\mathrm{O}_{3}$ & 12 layers (sfc-1 mbar) \\
\hline
\end{tabular}

\footnotetext{
Available in near-real-time for post flight analysis.

${ }^{\mathrm{b}}$ Available in real-time for chemical/aerosol data assimilation studies.
} 


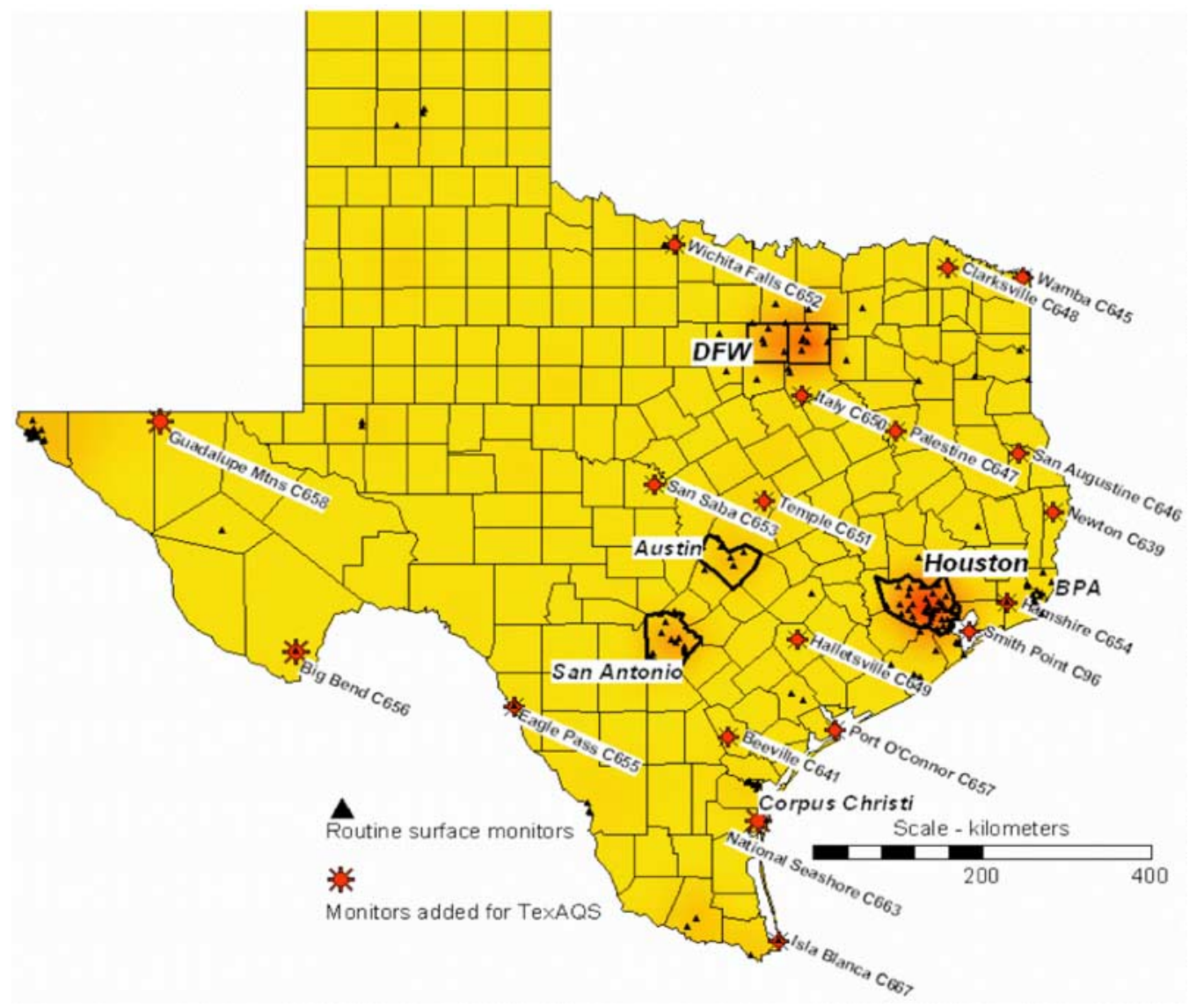

Figure B1. Map of air pollutant measurement sites, maintained by the TCEQ. Triangles indicate the approximately 100 continuously operating sites, and red stars indicate sites added for TexAQS II to improve the characterization of regional transport of air pollutants.

Table B1. Locations and Measurements of the 16 Surface Sites Specially Deployed by TCEQ for the TexAQS II Study ${ }^{a}$

\begin{tabular}{|c|c|c|c|c|}
\hline CAMS & Site Description & $\begin{array}{c}\text { Surface } \\
\text { Measurements }\end{array}$ & Latitude & Longitude \\
\hline C638 & $\begin{array}{l}\text { Smith Point } \\
\text { Hawkins Camp }\end{array}$ & Ozone, met & 29.546 & -94.787 \\
\hline C639 & Newton NTRD & Ozone, met & 30.885 & -93.742 \\
\hline C645 & Wamba NTRD & Ozone, met & 33.500 & -94.120 \\
\hline C646 & $\begin{array}{l}\text { San Augustine } \\
\text { Airport NTRD }\end{array}$ & $\begin{array}{l}\text { Ozone, neph, } \\
\text { met, } 2.5 \text { filter }\end{array}$ & 31.539 & -94.170 \\
\hline C648 & Clarksville NTRD & $\begin{array}{l}\text { Ozone, neph, } \\
\text { met, } 2.5 \text { filter }\end{array}$ & 33.620 & -95.060 \\
\hline C641 & Beeville Airport & Ozone, met & 28.360 & -97.790 \\
\hline C649 & Halletsville & Ozone, met & 29.447 & -96.933 \\
\hline C650 & Italy High School & Ozone, met & 32.178 & -96.878 \\
\hline C651 & Temple & Ozone, met & 30.998 & -97.339 \\
\hline C652 & $\begin{array}{c}\text { Wichita Falls } \\
\text { TexAQSII }\end{array}$ & $\begin{array}{l}\text { neph, met, } \\
2.5 \text { filter }\end{array}$ & 33.870 & -98.460 \\
\hline C653 & $\begin{array}{l}\text { Millpond Park } \\
\text { San Saba }\end{array}$ & $\begin{array}{l}\text { neph, met, } \\
2.5 \text { filter }\end{array}$ & 31.187 & -98.712 \\
\hline C654 & Hamshire & $\begin{array}{l}\text { Ozone, neph, } \mathrm{NO}_{\mathrm{x}} \text {, } \\
2.5 \text { teom, met }\end{array}$ & 29.864 & -94.318 \\
\hline C655 & Eagle Pass & neph, 2.5 teom, met & 28.702 & -100.451 \\
\hline C647 & Palestine & Ozone, met & 31.779 & -95.706 \\
\hline C657 & Port O Connor & Ozone, 2.5 teom, met & 28.434 & -96.455 \\
\hline C667 & Isla Blanca & Ozone, neph, met & 26.073 & -97.167 \\
\hline
\end{tabular}

${ }^{\mathrm{a}}$ Abbreviations: CAMS, Continuous Ambient Monitoring Stations; met, surface wind, temperature, and humidity measurements; neph, 3 wavelength nephelometer; 2.5 filter, PM2.5 mass measurements by filter collection; and teom, PM 2.5 mass measurements by Tapered Element Oscillating Microbalance.

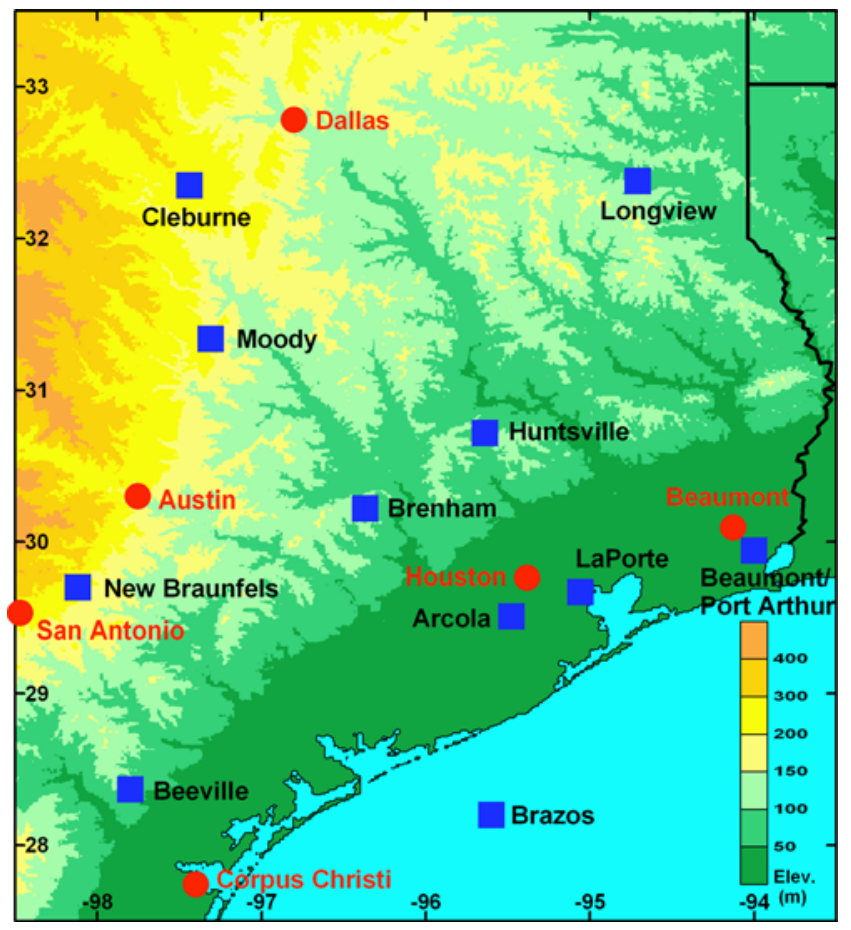

Figure B2. Map of observing sites (blue squares) in the TexAQS II boundary layer radar wind profiler network. Red circles indicate Texan urban areas. 
Table B2. Locations of Boundary Layer Radar Wind Profilers Deployed for the TexAQS II Study ${ }^{\mathrm{a}}$

\begin{tabular}{|c|c|c|c|c|c|c|}
\hline Location & Designation & Latitude & Longitude & Elevation & RASS & Sponsor \\
\hline Arcola, Tex. & $\mathrm{ACL}$ & 29.51 & -95.48 & $21 \mathrm{~m}$ & yes & NOAA \\
\hline Beaumont-Port Arthur, Tex. & BPA & 30.10 & -94.10 & $24 \mathrm{~m}$ & no & TCEQ \\
\hline Beeville, Tex. & BVL & 28.37 & -97.80 & $75 \mathrm{~m}$ & yes & NOAA \\
\hline $\begin{array}{l}\text { Brazos A-19 Oil Platform in } \\
\text { the Gulf of Mexico }\end{array}$ & $\mathrm{BRZ}$ & 28.20 & -95.60 & $24 \mathrm{~m}$ & no & $\begin{array}{l}\text { Sonoma } \\
\text { Technology }\end{array}$ \\
\hline Brenham, Tex. & BHM & 30.22 & -96.37 & $94 \mathrm{~m}$ & yes & NOAA \\
\hline Cleburne, Tex. & CLE & 32.35 & -97.44 & $250 \mathrm{~m}$ & no & TCEQ \\
\hline Huntsville, Tex. & HVE & 30.72 & -95.64 & $101 \mathrm{~m}$ & yes & NOAA \\
\hline LaPorte, Tex. & LPT & 29.61 & -95.17 & $8 \mathrm{~m}$ & no & TCEQ \\
\hline Longview, Tex. & LVW & 32.38 & -94.71 & $106 \mathrm{~m}$ & yes & NOAA \\
\hline Moody, Tex. & MDY & 31.34 & -97.31 & $250 \mathrm{~m}$ & yes & NOAA \\
\hline New Braunfels, Tex. & NBF & 29.70 & -98.12 & $195 \mathrm{~m}$ & yes & $\begin{array}{l}\text { Sonoma } \\
\text { Technology }\end{array}$ \\
\hline R/V Ronald H. Brown & RHB & variable & variable & $5 \mathrm{~m}$ & no & NOAA \\
\hline
\end{tabular}

${ }^{\mathrm{a}}$ Radio acoustic sounding system.

and after the study to help scientists understand regional transport patterns and pollution source apportionment.

[93] Most meteorological observations have been collected and made available through the Texas A\&M University web site, http://atmo.tamu.edu/texaqs $2 /$. In addition to data, the Web site includes quick-look maps and images along with descriptions of the meteorology and ozone during days of particular interest.

[94] Acknowledgments. The Air Quality and the Climate Research and Modeling Programs of the National Oceanic and Atmospheric Administration (NOAA) and the Texas Commission on Environmental Quality (TCEQ) supported the WP-3D, $\mathrm{O}_{3}$ Lidar aircraft, and Ronald H. Brown R/V measurements. The CIRPAS Twin Otter was supported by the NOAA Climate Program Office under grant NA06OAR4310082. Support for the HSRL deployment and analyses of data was provided by the NASA Science Mission Directorate, the NASA CALIPSO project, the Texas Commission on Environment Quality (TCEQ), and the Office of Science (BER), U. S. Department of Energy (Atmospheric Science Program), Interagency Agreement DE-AI02-05ER6398.

\section{References}

Arnott, W. P., H. Moosmuller, C. F. Rogers, T. F. Jin, and R. Bruch (1999), Photoacoustic spectrometer for measuring light absorption by aerosol: Instrument description, Atmos. Environ., 33, 2845-2852, doi:10.1016/ S1352-2310(98)00361-6.

Arnott, W. P., J. W. Walker, I. Moosmuller, R. A. Elleman, H. H. Jonsson, G. Buzorius, W. C. Conant, R. C. Flagan, and J. H. Seinfeld (2006), Photoacoustic insight for aerosol light absorption aloft from meteorological aircraft and comparison with particle soot absorption photometer measurements: DOE Southern Great Plains climate research facility and the coastal stratocumulus imposed perturbation experiments, J. Geophys. Res., 111, D05S02, doi:10.1029/2005JD005964.

Bahreini, R., et al. (2003), Aircraft-based aerosol size and composition measurements during ACE-Asia using an Aerodyne aerosol mass spectrometer, J. Geophys. Res., 108(D23), 8645, doi:10.1029/2002JD003226.

Bahreini, R., E. J. Dunlea, B. M. Matthew, C. Simons, K. S. Docherty, P. F. DeCarlo, J. L. Jimenez, C. A. Brock, and A. M. Middlebrook (2008), Design and operation of a pressure-controlled inlet for airborne sampling with an aerodynamic aerosol lens, Aerosol Sci. Technol., 42(6), 465-471, doi:10.1080/02786820802178514.

0Bahreini, R., et al. (2009), Organic aerosol formation in urban and industrial plumes near Houston and Dallas, Texas, J. Geophys. Res., doi:10.1029/2008JD011493, in press.

Banta, R., C. Senff, J. Nielsen-Gammon, L. Darby, T. Ryerson, R. Alvarez, P. Sandberg, E. Williams, and M. Trainer (2005), A bad air day in Houston, Bull. Am. Meteorol. Soc., 86, 657-669, doi:10.1175/BAMS-86-5-657.

Bao, J.-W., S. A. Michelson, S. A. McKeen, and G. A. Grell (2005), Meteorological evaluation of a weather-chemistry forecasting model using observations from the TEXAS AQS 2000 field experiment, J. Geophys. Res., 110, D21105, doi:10.1029/2004JD005024.
Bates, T. S., P. K. Quinn, D. S. Covert, D. J. Coffman, J. E. Johnson, and A. Wiedensohler (2000), Aerosol physical properties and processes in the lower marine boundary layer: A comparison of shipboard sub-micron data from ACE 1 and ACE 2, Tellus, Ser. B, 52, 258-272, doi:10.1034/ j.1600-0889.2000.00021.x.

Bates, T. S., P. K. Quinn, D. J. Coffman, J. E. Johnson, T. L. Miller D. S. Covert, A. Wiedensohler, S. Leinert, A. Nowak, and C. Neusüß (2001), Regional physical and chemical properties of the marine boundary layer aerosol across the Atlantic during Aerosols99: An overview, J. Geophys. Res., 106, 20,767-20,782, doi:10.1029/2000JD900578.

Bates, T. S., P. K. Quinn, D. J. Coffman, J. E. Johnson, and A. M. Middlebrook (2005), Dominance of organic aerosols in the marine boundary layer over the Gulf of Maine during NEAQS 2002 and their role in aerosol light scattering, J. Geophys. Res., 110, D18202, doi:10.1029/2005JD005797.

Bates, T. S., et al. (2008), Boundary layer aerosol chemistry during TexAQS/ GoMACCS 2006: Insights into aerosol sources and transformation processes, J. Geophys. Res., 113, D00F01, doi:10.1029/2008JD010023.

Baumgardner, D., H. Jonsson, W. Dawson, C. O'Connor, and R. Newton (2001), The cloud, aerosol and precipitation spectrometer: A new instrument for cloud investigations, Atmos. Res., 59-60, 251-264, doi:10.1016/ S0169-8095(01)00119-3.

Baumgardner, D., G. Kok, and G. Raga (2004), Warming of the Arctic lower stratosphere by light absorbing particles, Geophys. Res. Lett., 31, L06117, doi:10.1029/2003GL018883.

Baynard, T., A. Pettersson, E. Lovejoy, S. Brown, D. Lack, P. Massoli, H. Osthoff, S. Ciciora, B. Dube, and A. R. Ravishankara (2007), Design and application of a pulsed cavity ring-down aerosol extinction spectrometer for field measurements, Aerosol Sci. Technol., 41(4), 447-462, doi:10.1080/02786820701222801.

Beer, R. (2006), TES on the Aura Mission: Scientific objectives, measurements, and analysis overview, IEEE Trans. Geosci. Remote Sens., 44, 1102-1105, doi:10.1109/TGRS.2005.863716.

Berkowitz, C. M., T. Jobson, G. Jiang, C. W. Spicer, and P. V. Doskey (2004), Chemical and meteorological characteristics associated with rapid increases of $\mathrm{O}_{3}$ in Houston, Texas, J. Geophys. Res., 109, D10307, doi:10.1029/2003JD004141.

Berkowitz, C. M., C. W. Spicer, and P. V. Doskey (2005), Hydrocarbon observations and ozone production rates in western Houston during the Texas 2000 Air Quality Study, Atmos. Environ., 39, 3383-3396, doi:10.1016/j.atmosenv.2004.12.007.

Bohn, B., A. Kraus, M. Müller, and A. Hofzumahaus (2004), Measurement of atmospheric $\mathrm{O}_{3} \rightarrow \mathrm{O}\left({ }^{1} \mathrm{D}\right)$ photolysis frequencies using filterradiometry, J. Geophys. Res., 109, D10S90, doi:10.1029/2003JD004319.

Bond, T. C., T. L. Anderson, and D. Campbell (1999), Calibration and intercomparison of filter-based measurements of visible light absorption by aerosols, Aerosol Sci. Technol., 30(6), 582-600, doi:10.1080/ 027868299304435

Brock, C. A., F. Schröder, B. Kärcher, A. Petzold, R. Busen, and M. Fiebig (2000), Ultrafine particle size distributions measured in aircraft exhaust plumes, J. Geophys. Res., 105, 26,555-26,567, doi:10.1029/ 2000JD900360.

Brock, C. A., et al. (2003), Particle growth in urban and industrial plumes in Texas, J. Geophys. Res., 108(D3), 4111, doi:10.1029/2002JD002746. 
Brooks, I. M. (2003), Finding boundary layer top: Application of a wavelet covariance transform to lidar backscatter profiles, J. Atmos. Oceanic Technol., 20(8), 1092-1105, doi:10.1175/1520-0426(2003)020< 1092:FBLTAO $>2.0 . \mathrm{CO} ; 2$.

Brown, S. G., and H. R. Hafner (2003), Exploratory source apportionment of Houston's Clinton Drive auto-GC 1998-2001 data, Rep. STI-900700-2317FR, 144 pp., Tex. Comm. on Environ. Qual., Austin. (Available at http:// www.tceq.state.tx.us/assets/public/implementation/air/am/contracts/reports/ da/Source_Apportionment_of_AutoGC_Data.pdf)

Brown, S. $\overline{\text { G., }}$ and H. Hafner Main (200ㄹ), Acquisition, review and analysis of auto-GC VOC data in the Houston area, 1998-2001: Final report, Rep. STI-900670-2224-FR, 199 pp., Tex. Nat. Resour. Conserv. Comm., Austin. (Available at http://www.tceq.state.tx.us/assets/public/ implementation/air/am/contracts/reports/da/AutoGC_VOC_Data_Houston Final Report.pdf)

Brown, S. G., P. T. Roberts, and J. A. Roney (2002), Preliminary characterization of 2001 event-triggered VOC and carbonyl samples, Rep. STI900680-2188-IR, 49 pp., Tex. Nat. Resour. Conserv. Comm., Austin.

Brown, S. S., et al. (2006), Variability in nocturnal nitrogen oxide processing and its role in regional air quality, Science, 311, 67-70.

Brown, S. S., et al. (2009), Reactive uptake coefficients for $\mathrm{N}_{2} \mathrm{O}_{5}$ determined from aircraft measurements during the Second Texas Air Quality Study: Comparison to current model parameterizations, J. Geophys. Res. 114, D00F10, doi:10.1029/2008JD011679.

Browning, K. A., and R. Wexler (1968), The determination of kinematic properties of a wind field using Doppler radar, J. Appl. Meteorol., 7 , 105-113, doi:10.1175/1520-0450(1968)007<0105:TDOKPO >2.0.CO;2.

Buzcu, B., and M. P. Fraser (2006), Source identification and apportionment of volatile organic compounds in Houston, TX, Atmos. Environ., 40, 2385-2400, doi:10.1016/j.atmosenv.2005.12.020.

Buzcu-Guven, B., and M. P. Fraser (2008), Comparison of VOC emissions inventory data with source apportionment results for Houston, TX, Atmos. Environ., 42, 5032-5043, doi:10.1016/j.atmosenv.2008.02.025.

Buzorius, G. (2001), Cut-off sizes and time constants of the CPC TSI 3010 operating at 1-3 lpm flow rates, Aerosol Sci. Technol., 35(1), 577-585.

Byun, D. W., S. Kim, B. Czader, D. Nowak, S. Stetson, and M. Estes (2005a), Estimation of biogenic emissions with satellite-derived land use and land cover data for air quality modeling of Houston-Galveston ozone nonattainment area, J. Environ. Manage., 75, 285-301, doi:10.1016/j.jenvman.2004.10.009.

Byun, D. W., S.-T. Kim, B. Czader, F.-Y. Cheng, S.-B. Kim, P. Percell, H.-J. In, C.-K. Song, V. Coarfa, and F. Ngan (2005b), Role of modeling assumptions in the Houston midcourse review, final report, 90 pp., Houston Adv. Res. Cent., Houston, Tex.

Byun, D. W., S.-T. Kim, and S.-B. Kim (2007), Evaluation of air quality models for the simulation of a high ozone episode in the Houston metropolitan area, Atmos. Environ., 41, 837-853, doi:10.1016/j.atmosenv. 2006.08.038.

Carrico, C. M., P. Kus, M. J. Rood, P. K. Quinn, and T. S. Bates (2003), Mixtures of pollution, dust, sea salt and volcanic aerosol during ACE-Asia: Light scattering properties as a function of relative humidity, J. Geophys. Res., 108(D23), 8650, doi:10.1029/2003JD003405.

Carter, D. A., K. S. Gage, W. L. Ecklund, W. M. Angevine, P. E. Johnston, A. C. Riddle, J. Wilson, and C. R. Williams (1995), Developments in UHF lower tropospheric wind profiling technology at NOAA's Aeronomy Laboratory, Radio Sci., 30(4), 977-1001, doi:10.1029/95RS00649.

Cerni, T. A. (1983), Determination of the size and concentration of cloud drops with an FSSP, J. Clim. Appl. Meteorol., 22(8), 1346-1355, doi:10.1175/1520-0450(1983)022<1346:DOTSAC >2.0.CO;2.

Cheng, F.-Y., and D. W. Byun (2008), Application of high resolution land use and land cover data for atmospheric modeling in the HoustonGalveston metropolitan area: Part I. Meteorological simulation results, Atmos. Environ., 42, 7795-7811, doi:10.1016/j.atmosenv.2008.04.055.

Cheng, F.-Y., S. Kim, and D. W. Byun (2008), Application of high resolution land use and land cover data for atmospheric modeling in the HoustonGalveston Metropolitan area: Part II. Air quality simulation results, Atmos. Environ., 42, 4853-4869, doi:10.1016/j.atmosenv.2008.02.059.

Chuang, P. Y., E. W. Saw, J. D. Small, R. A. Shaw, C. M. Sipperley, G. A. Payne, and W. D. Bachalo (2008), Airborne phase Doppler interferometry for cloud microphysical measurements, Aerosol Sci. Technol., 42(8), 685-703, doi:10.1080/02786820802232956.

Cimini, D., J. A. Shaw, E. R. Westwater, Y. Han, V. Irisov, V. Leuski, and J. H. Churnside (2003), Air temperature profile and air/sea temperature difference measurements by infrared and microwave scanning radiometers, Radio Sci., 38(3), 8045, doi:10.1029/2002RS002632.

Cohn, S. A., and W. M. Angevine (2000), Boundary-layer height and entrainment zone thickness measured by lidars and wind profiling radars,
J. Appl. Meteorol., 39, 1233-1247, doi:10.1175/1520-0450(2000) 039<1233:BLHAEZ $>2.0$. CO;2.

Comstock, K. K., C. S. Bretherton, and S. E. Yuter (2005), Mesoscale variability and drizzle in southeast Pacific stratocumulus, J. Atmos. Sci. 62, 3792-3807, doi:10.1175/JAS3567.1.

Cooper, O. R., et al. (2007), Evidence for a recurring eastern North America upper tropospheric ozone maximum during summer, J. Geophys. Res., 112, D23304, doi:10.1029/2007JD008710.

Czader, B. H., D. W. Byun, S.-T. Kim, and W. P. L. Carter (2008), A study of $\mathrm{VOC}$ reactivity in the Houston-Galveston air mixture utilizing an extended version of SAPRC-99 chemical mechanism, Atmos. Environ., 42, 5733-5742, doi:10.1016/j.atmosenv.2008.01.039.

Darby, L. S. (2005), Cluster analysis of surface winds in Houston, Texas, and the impact of wind patterns on ozone, J. Appl. Meteorol., 44, 17881806, doi:10.1175/JAM2320.1.

Daube, B. C., Jr., K. A. Boering, A. E. Andrews, and S. C. Wofsy (2002), A high-precision fast-response airborne $\mathrm{CO}_{2}$ analyzer for in situ sampling from the surface to the middle stratosphere, J. Atmos. Oceanic Technol., 19(10), 1532 - 1543, doi:10.1175/1520-0426(2002)019<1532:AHPFRA > 2.0.CO;2.

Daum, P. H., L. I. Kleinman, S. R. Springston, L. J. Nunnermacker, Y.-N. Lee, J. Weinstein-Lloyd, J. Zheng, and C. M. Berkowitz (2003), A comparative study of $\mathrm{O}_{3}$ formation in the Houston urban and industrial plumes during the 2000 Texas Air Quality Study, J. Geophys. Res., 108(D23), 4715, doi:10.1029/2003JD003552.

Daum, P. H., L. I. Kleinman, S. R. Springston, L. J. Nunnermacker, Y.-N. Lee, J. Weinstein-Lloyd, J. Zheng, and C. M. Berkowitz (2004), Origin and properties of plumes of high ozone observed during the Texas 2000 Air Quality Study (TexAQS 2000), J. Geophys. Res., 109, D17306, doi:10.1029/2003JD004311.

Davis, K. J., N. Gamage, C. R. Hagelberg, C. Kiemle, D. H. Lenschow, and P. P. Sullivan (2000), An objective method for deriving atmospheric structure from airborne lidar observations, J. Atmos. Oceanic Technol., 17(11), 1455-1468, doi:10.1175/1520-0426(2000)017<1455:AOMFDA> 2.0.CO;2.

DeCarlo, P. F., et al. (2006), Field-deployable, high-resolution, time-of-flight aerosol mass spectrometer, Anal. Chem., 78, 8281-8289, doi:10.1021/ ac061249n.

de Gouw, J. A., et al. (2003), Sensitivity and specificity of atmospheric trace gas detection by proton-transfer-reaction mass spectrometry, Int J. Mass Spectrom., 223-224, 365-382.

de Gouw, J. A., et al. (2009), Airborne measurements of ethene from industrial sources using laser photo-acoustic spectroscopy, Environ. Sci. Technol., 43, 2437-2442.

Dibb, J. E., E. Scheuer, S. I. Whitlow, M. Vozella, E. Williams, and B. Lerner (2004), Ship-based nitric acid measurements in the Gulf of Maine during New England Air Quality Study 2002, J. Geophys. Res., 109, D20303, doi:10.1029/2004JD004843.

Diner, D. J., et al. (1998), Multi-angle Imaging SpectroRadiometer (MISR) description and experiment overview, IEEE Trans. Geosci. Remote Sens., 36, 1072-1087, doi:10.1109/36.700992

Dubé, W. P., S. S. Brown, H. D. Osthoff, M. R. Nunley, S. J. Ciciora, M. W. Paris, R. J. McLaughlin, and A. R. Ravishankara (2006), Aircraft instrument for simultaneous, in-situ measurements of $\mathrm{NO}_{3}$ and $\mathrm{N}_{2} \mathrm{O}_{5}$ via cavity ring-down spectroscopy, Rev. Sci. Instrum., 77, 034101, doi:10.1063/1.2176058.

Eisele, F. L., and D. J. Tanner (1993), Measurement of the gas phase concentration of $\mathrm{H}_{2} \mathrm{SO}_{4}$ and methane sulfonic acid and estimates of $\mathrm{H}_{2} \mathrm{SO}_{4}$ production and loss in the atmosphere, J. Geophys. Res., 98, 9001-9010, doi:10.1029/93JD00031.

Environmental Protection Agency (2004), The oxone report: Measuring progress through 2003, EPA 454/K-04-001, 19 pp., Research Triangle Park, N. C.

Estes, M., S. Wharton, D. Boyer, Z. Fang, J. Smith, S. McDowell, F. Mercado, J. Neece, E. Gribbin, and J. Price (2002), Analysis of automated gas chromatograph data from 1996-2001 to determine VOCs with largest ozone formation potential, Houston-Galveston-Brazoria Ozone SIP Rev. Tech. Supp. Doc. Attachment 6, 50 pp., Tex. Comm. on Environ. Qual., Austin. (Available at http://www.tceq.state.tx.us/assets/public/ implementation/air/am/docs/hgb/tsd1/attachment6-agc_voc.pdf)

Fairall, C. W., A. B. White, J. B. Edson, and J. E. Hare (1997), Integrated shipboard measurements of the marine boundary layer, J. Atmos. Oceanic Technol., 14(3), 338-359, doi:10.1175/1520-0426(1997) $014<0338$ :ISMOTM>2.0.CO;2.

Fairall, C. W., E. F. Bradley, J. E. Hare, A. A. Grachev, and J. B. Edson (2003), Bulk parameterization of air-sea fluxes: Updates and verification 
for the COARE algorithm, J. Clim., 16, 571-591, doi:10.1175/1520-0442 (2003)016<0571:BPOASF $>2.0 . \mathrm{CO} ; 2$.

Fairall, C. W., L. Bariteau, A. A. Grachev, R. J. Hill, D. E. Wolfe, W. A. Brewer, S. C. Tucker, J. E. Hare, and W. M. Angevine (2006), Turbulent bulk transfer coefficients and ozone deposition velocity in the International Consortium for Atmospheric Research into Transport and Transformation, J. Geophys. Res., 111, D23S20, doi:10.1029/ 2006JD007597.

Faraji, M., Y. Kimura, E. McDonald-Buller, and D. Allen (2008), Comparison of the carbon bond and SAPRC photochemical mechanisms under conditions relevant to southeast Texas, Atmos. Environ., 42, 5821-5836, doi:10.1016/j.atmosenv.2007.07.048.

Fast, J. D., W. I. Gustafson Jr., R. C. Easter, R. A. Zaveri, J. C. Barnard, E. G. Chapman, G. A. Grell, and S. E. Peckham (2006), Evolution of ozone, particulates, and aerosol direct radiative forcing in the vicinity of Houston using a fully coupled meteorology-chemistry-aerosol model, J. Geophys. Res., 111, D21305, doi:10.1029/2005JD006721.

Fehsenfeld, F., et al. (1990), Intercomparison of $\mathrm{NO}_{2}$ measurement techniques, J. Geophys. Res., 95, 3579-3597, doi:10.1029/JD095iD04p03579.

Fehsenfeld, F. C., et al. (2006), International Consortium for Atmospheric Research on Transport and Transformation (ICARTT): North America to Europe-Overview of the 2004 summer field study, J. Geophys. Res., 111, D23S01, doi:10.1029/2006JD007829.

Frisch, A. S., B. E. Martner, and J. S. Gibson (1989), Measurement of the vertical flux of turbulent kinetic energy with a single Doppler radar, Boundary Layer Meteorol., 49, 331-337, doi:10.1007/BF00123648.

Gerber, H., B. G. Arends, and A. S. Ackerman (1994), New microphysics sensor for aircraft use, Atmos. Res., 31, 235-252, doi:10.1016/01698095(94)90001-9.

Gerbig, C., S. Schmitgen, D. Kley, A. Volz-Thomas, K. Dewey, and D. Haaks (1999), An improved fast-response VUV resonance fluorescence CO instrument, J. Geophys. Res., 104, 1699-1704, doi:10.1029/ 1998JD100031.

Giglio, L., J. Descloitres, C. O. Justice, and Y. Kaufman (2003), An enhanced contextual fire detection algorithm for MODIS, Remote Sens. Environ., 87, 273-282, doi:10.1016/S0034-4257(03)00184-6.

Gilardoni, S., et al. (2007), Regional variation of organic functional groups in aerosol particles on four U.S. east coast platforms during the International Consortium for Atmospheric Research on Transport and Transformation 2004 campaign, J. Geophys. Res., 112, D10S27, doi:10.1029/ 2006JD007737.

Gilman, J. B., et al. (2009), Measurements of volatile organic compounds during the 2006 TexAQS/GoMACCS campaign: Industrial influences, regional characteristics, and diurnal dependencies of the $\mathrm{OH}$ reactivity, J. Geophys. Res., 114, D00F06, doi:10.1029/2008JD011525.

Goldan, P. D., W. C. Kuster, E. Williams, P. C. Murphy, F. C. Fehsenfeld, and J. Meagher (2004), Nonmethane hydrocarbon and oxy hydrocarbon measurements during the 2002 New England Air Quality Study, J. Geophys. Res., 109, D21309, doi:10.1029/2003JD004455.

Green, T. J., et al. (2006), An improved dual channel PERCA instrument for atmospheric measurements of peroxy radicals, J. Environ. Monit., 8 , 530-536, doi:10.1039/b514630e.

Grund, C. J., R. M. Banta, J. L. George, J. N. Howell, M. J. Post, R. A Richter, and A. M. Weickmann (2001), High-resolution Doppler lidar for boundary layer and cloud research, J. Atmos. Oceanic Technol., 18(3), 376-393, doi:10.1175/1520-0426(2001)018<0376:HRDLFB>2.0.CO;2.

Gurka, J. J., E. M. Prins, T. J. Schmit, and A. J. Schreiner (2001), Introducing the GOES-M Imager, Nat. Weather Dig., 25(3-4), 28-37.

Hafner Main, H., T. O’Brien, C. Hardy, S. Wharton, and D. Sullivan (2001), Characterization of auto-GC data in Houston, report, $81 \mathrm{pp}$., Tex. Nat. Resour. Conserv. Comm., Austin. (Available at http://www. tceq.state.tx.us/assets/public/implementation/air/am/contracts/reports/da/ CharacterizationAutoGCdata.pdf)

Hair, J. W., C. A. Hostetler, A. L. Cook, D. B. Harper, R. A. Ferrare, T. L. Mack, W. Welch, L. R. Isquierdo, and F. E. Hovis (2008), Airborne high spectral resolution lidar for profiling aerosol optical properties, Appl. Opt., 47, 6734-6752, doi:10.1364/AO.47.006734.

Herndon, S. C., M. S. Zahniser, D. D. Nelson Jr., J. Shorter, J. B. McManus, R. Jiménez, C. Warneke, and J. A. de Gouw (2007), Airborne measurements of $\mathrm{HCHO}$ and $\mathrm{HCOOH}$ during the New England Air Quality Study 2004 using a pulsed quantum cascade laser spectrometer, J. Geophys. Res., 112, D10S03, doi:10.1029/2006JD007600.

Holloway, J. S., R. O. Jakoubek, D. D. Parrish, C. Gerbig, A. Volz-Thomas, S. Schmitgen, A. Fried, B. Wert, B. Henry, and J. R. Drummond (2000), Airborne intercomparison of vacuum ultraviolet fluorescence and tunable diode laser absorption measurements of tropospheric carbon monoxide, J. Geophys. Res., 105, 24,251-24,261, doi:10.1029/2000JD900237.

Jayne, J. T., D. C. Leard, X. F. Zhang, P. Davidovits, K. A. Smith, C. E. Kolb, and D. R. Worsnop (2000), Development of an aerosol mass spec- trometer for size and composition analysis of submicron particles, Aerosol Sci. Technol., 33(1-2), 49-70, doi:10.1080/027868200410840.

Jiang, G., and J. D. Fast (2004), Modeling the effects of VOC and NOx emission sources on ozone formation in Houston during the TexAQS 2000 field campaign, Atmos. Environ., 38, 5071 -5085, doi:10.1016/j.atmosenv. 2004.06.012.

Jiang, H., G. Feingold, H. H. Jonsson, M.-L. Lu, P. Y. Chuang, R. C. Flagan, and J. H. Seinfeld (2008), Statistical comparison of properties of simulated and observed cumulus clouds in the vicinity of Houston during the Gulf of Mexico Atmospheric Composition and Climate Study (GoMACCS), J. Geophys. Res., 113, D13205, doi:10.1029/2007JD009304. Jiang, X., C. Wiedinmyer, F. Chen, Z.-L. Yang, and J. C.-F. Lo (2008), Predicted impacts of climate and land use change on surface ozone in the Houston, Texas, area, J. Geophys. Res., 113, D20312, doi:10.1029/ 2008JD009820.

Jobson, B. T., C. M. Berkowitz, W. C. Kuster, P. D. Goldan, E. J. Williams, F. C. Fesenfeld, E. C. Apel, T. Karl, W. A. Lonneman, and D. Riemer (2004), Hydrocarbon source signatures in Houston, Texas: Influence of the petrochemical industry, J. Geophys. Res., 109, D24305, doi:10.1029/ 2004JD004887.

Karl, T., T. Jobson, W. C. Kuster, E. Williams, J. Stutz, R. Shetter, S. R. Hall, P. Goldan, F. Fehsenfeld, and W. Lindinger (2003), Use of proton transfer-reaction mass spectrometry to characterize volatile organic compound sources at the La Porte super site during the Texas Air Quality Study 2000, J. Geophys. Res., 108(D16), 4508, doi:10.1029/2002JD003333. Kaufman, Y. J., D. Tanre, L. A. Remer, E. F. Vermote, A. Chu, and B. N. Holben (1997), Operational remote sensing of tropospheric aerosol over land from EOS moderate resolution imaging spectroradiometer, J. Geophys. Res., 102, 17,051-17,067, doi:10.1029/96JD03988.

Kemball-Cook, S., C. Emery, and G. Yarwood (2005), Impact and role of air quality modeling assumptions in the development of revisions to the Houston State Implementation Plan for attaining the ozone air quality standard, Rep. H12-8HR-B, 77 pp., Houston Adv. Res. Cent., Houston, Tex. (Available at http://files.harc.edu/Projects/AirQuality/Projects/ H012.2004/8HRB/H12-8HRBFinalReportUT.pdf)

Kemball-Cook, S., D. Parrish, T. Ryerson, U. Nopmongcol, J. Johnson, E. Tai, and G. Yarwood (2009), Contributions of regional transport and local sources to ozone exceedances in Houston and Dallas: Comparison of results from a photochemical grid model to aircraft and surface measurements, J. Geophys. Res., 114, D00F02, doi:10.1029/2008JD010248.

Kim, E., S. G. Brown, H. R. Hafner, and P. K. Hopke (2005), Characterization of non-methane volatile organic compounds sources in Houston during 2001 using positive matrix factorization, Atmos. Environ., 39 , 5934-5946, doi:10.1016/j.atmosenv.2005.06.045.

Kleinman, L. I., P. H. Daum, D. Imre, Y.-N. Lee, L. J. Nunnermacker, S. R. Springston, J. Weinstein-Lloyd, and J. Rudolph (2002), Ozone production rate and hydrocarbon reactivity in 5 urban areas: A cause of high ozone concentration in Houston, Geophys. Res. Lett., 29(10), 1467, doi:10.1029/2001GL014569.

Kleinman, L. I., P. H. Daum, D. Imre, Y.-N. Lee, L. J. Nunnermacker, S. R. Springston, J. Weinstein-Lloyd, and J. Rudolph (2003), Correction to "Ozone production rate and hydrocarbon reactivity in 5 urban areas: A cause of high ozone concentration in Houston,", Geophys. Res. Lett. 30(12), 1639, doi:10.1029/2003GL017485.

Kleinman, L. I., P. H. Daum, Y.-N. Lee, L. J. Nunnermacker, S. R. Springston, J. Weinstein-Lloyd, and J. Rudolph (2005), A comparative study of ozone production in five U.S. metropolitan areas, J. Geophys. Res., 110, D02301, doi:10.1029/2004JD005096.

Knapp, K. R., T. H. Vonder Haar, and Y. J. Kaufman (2002), Aerosol optical depth retrieval from GOES-8: Uncertainty study and retrieval validation over South America, J. Geophys. Res., 107(D7), 4055 doi:10.1029/2001JD000505.

Kollias, P., B. A. Albrecht, R. Lhermitte, and A. Savtchenko (2001), Radar observations of updrafts, downdrafts, and turbulence in fair-weather cumuli, J. Atmos. Sci., 58, 1750-1766, doi:10.1175/1520-0469(2001)058< 1750:ROOUDA $>2.0 . \mathrm{CO} ; 2$

Koo, B., G. Yarwood, and D. Cohan (2008), Higher-order decoupled direct method (HDDM) for ozone modeling sensitivity analyses and code refinements, report, 94 pp., Environ, Novato, Calif. (Available at http://www. tceq.state.tx.us/assets/public/implementation/air/am/contracts/reports/pm/ 5820784005FY0807-20080831-environ-camx hddm final report.pdf)

Lack, D. A., E. R. Lovejoy, T. Baynard, A. Pettersson, and A. R. Ravishankara (2006), Aerosol absorption measurement using photoacoustic spectroscopy: Sensitivity, calibration, and uncertainty developments, Aerosol Sci. Technol., 40(9), 697-708, doi:10.1080/02786820600803917.

Lack, D., B. Lerner, C. Granier, T. Baynard, E. Lovejoy, P. Massoli, A. R. Ravishankara, and E. Williams (2008), Light absorbing carbon emissions from commercial shipping, Geophys. Res. Lett., 35, L13815, doi:10.1029/ 2008 GL033906. 
Lack, D., et al. (2009), Particulate emissions from commercial shipping: Chemical, physical and optical properties, J. Geophys. Res., 114, D00F04, doi:10.1029/2008JD011300.

Lance, S., J. Medina, J. N. Smith, and A. Nenes (2006), Mapping the operation of the DMT continuous flow CCN counter, Aerosp. Sci. Technol., 40, 242-254, doi:10.1080/02786820500543290.

Lance, S., A. Nenes, H. Gates, V. Varutbangkul, T. Rissman, S. Murphy, R. Flagan, J. Seinfeld, G. Feingold, and H. Jonsson (2009), CCN activity, closure, and droplet growth kinetics of Houston aerosol during the Gulf of Mexico Atmospheric Composition and Climate Study (GoMACCS), J. Geophys. Res., doi:10.1029/2008JD011699, in press.

Langford, A. O., C. J. Senff, R. M. Banta, R. M. Hardesty, R. J. Alvarez II, S. P. Sandberg, and L. S. Darby (2009), Regional and background ozone in Houston during TexAQS 2006, J. Geophys. Res., doi:10.1029/ 2008JD011687, in press.

Law, D. C., S. A. McLaughlin, M. J. Post, B. L. Weber, D. C. Welsh, D. E. Wolfe, and D. A. Merritt (2002), An electronically stabilized phased array system for shipborne atmospheric wind profiling, J. Atmos. Oceanic Technol., 19(6), 924-933, doi:10.1175/1520-0426(2002) $019<0924$ :AESPAS $>2.0$.CO;2.

Levelt, P. F., G. H. J. van den Oord, M. R. Dobber, A. Malkki, H. Visser, J. de Vries, P. Stammes, J. O. V. Lundell, and H. Saari (2006a), The Ozone Monitoring Instrument, IEEE Trans. Geosci. Remote Sens., 44, 1093-1101, doi:10.1109/TGRS.2006.872333.

Levelt, P. F., E. Hilsenrath, G. W. Leppelmeier, G. H. J. van den Oord, P. K. Bhartia, J. Tamminen, J. F. de Haan, and J. P. Veefkind (2006b), Science objectives of the Ozone Monitoring Instrument, IEEE Trans. Geosci. Remote Sens., 44, 1199-1208, doi:10.1109/TGRS.2006.872336.

Liu, Z., et al. (2008), CALIPSO lidar observations of the optical properties of Saharan dust: A case study of long-range transport, J. Geophys. Res., 113, D07207, doi:10.1029/2007JD008878.

Lu, M.-L., G. Feingold, H. H. Jonsson, P. Y. Chuang, H. Gates, R. C. Flagan, and J. H. Seinfeld (2008), Aerosol-cloud relationships in continental shallow cumulus, J. Geophys. Res., 113, D15201, doi:10.1029/ 2007JD009354.

Massoli, P., T. S. Bates, P. K. Quinn, D. A. Lack, T. Baynard, B. M. Lerner, S. C. Tucker, J. Brioude, A. Stohl, and E. J. Williams (2009), Aerosol optical and hygroscopic properties during TexAQS-GoMACCS 2006 and their impact on aerosol direct radiative forcing, J. Geophys. Res., 114, D00F07, doi:10.1029/2008JD011604.

McGaughey, G. R., N. R. Desai, D. T. Allen, R. L. Seila, W. A. Lonneman, M. P. Fraser, R. A. Harley, J. M. Ivy, and J. H. Price (2004), Analysis of motor vehicle emissions in a Houston tunnel during the Texas Air Quality Study 2000, Atmos. Environ., 38, 3363-3372, doi:10.1016/j.atmosenv. 2004.03.006.

McKeen, S., et al. (2009), An evaluation of real-time air quality forecasts and their urban emissions over eastern Texas during the summer of Second Texas Air Quality Study (TexAQS II) field study, J. Geophys. Res., 114, D00F11, doi:10.1029/2008JD011697.

McMillan, W. W., C. Barnet, L. Strow, M. T. Chahine, M. L. McCourt, J. X. Warner, P. C. Novelli, S. Korontzi, E. S. Maddy, and S. Datta (2005), Daily global maps of carbon monoxide from NASA's Atmospheric Infrared Sounder, Geophys. Res. Lett., 32, L11801, doi:10.1029/ 2004GL021821.

Mellqvist, J., J. Samuelsson, C. Rivera, B. Lefer, and M. Patel (2007), Measurements of industrial emissions of VOCs, $\mathrm{NH}_{3}, \mathrm{NO}_{2}$ and $\mathrm{SO}_{2}$ in Texas using the Solar Occultation Flux method and mobile DOAS, report, p. 69, Houston Adv. Res. Cent., Houston, Tex. (Available at http:// www.tercairquality.org/AQR/Projects/H053.2005)

Mertes, S., F. Schroder, and A. Wiedensohler (1995), The particle-detection efficiency curve of the Tsi-3010 CPC as a function of the temperature difference between saturator and condenser, Aerosol Sci. Technol., 23(2), 257-261, doi:10.1080/02786829508965310.

Murphy, C. F., and D. T. Allen (2005), Hydrocarbon emissions from industrial release events in the Houston-Galveston area and their impact on ozone formation, Atmos. Environ., 39, 3785-3798, doi:10.1016/j.atmosenv. 2005.02.051

Nam, J., Y. Kimura, W. Vizuete, C. Murphy, and D. T. Allen (2006), Modeling the impacts of emission events on ozone formation in Houston, Texas, Atmos. Environ., 40, 5329-5341, doi:10.1016/j.atmosenv. 2006.05.002.

Neuman, J. A., et al. (2002), Fast-response airborne in situ measurement of $\mathrm{HNO}_{3}$ during the Texas Air Quality Study, J. Geophys. Res., 107(D20), 4436, doi:10.1029/2001JD001437.

Neuman, J. A., et al. (2009), Relationship between photochemical ozone production and $\mathrm{NO}_{\mathrm{x}}$ oxidation in Houston, Texas, J. Geophys. Res., 114, D00F08, doi:10.1029/2008JD011688.

Ngan, F., and D. Byun (2008), The analysis of ozone dependence on synoptic weather patterns, paper presented at 7 th Annual Community
Model and Analysis System Conference, Univ. of N. C. at Chapel Hill, Chapel Hill. (Available at http://www.cmascenter.org/conference/2008/ slides/ngan_analysis_ozone_cmas08.ppt)

Nielsen-Gammon, J., J. Tobin, and A. McNeel (2005a), A conceptual model for eight-hour ozone exceedances in Houston, Texas, part I: Background ozone levels in eastern Texas, research report, Houston Adv. Res. Cent., Houston, Tex.

Nielsen-Gammon, J., J. Tobin, and A. McNeel (2005b), A conceptual model for eight-hour ozone exceedances in Houston, Texas, part II: Eight-hour ozone exceedances in the Houston-Galveston metropolitan area, research report, Houston Adv. Res. Cent., Houston, Tex. (Available at http:// www.tercairquality.org/AQR/Projects/H012.2004.8HRB)

Nielsen-Gammon, J. W., R. T. McNider, W. M. Angevine, A. B. White, and K. Knupp (2007), Mesoscale model performance with assimilation of wind profiler data: Sensitivity to assimilation parameters and network configuration, J. Geophys. Res., 112, D09119, doi:10.1029/2006JD007633.

Noone, K. J., J. A. Ogren, J. Heintzenberg, R. J. Charlson, and D. S. Covert (1988), Design and calibration of a counterflow virtual impactor for sampling of atmospheric fog and cloud droplets, Aerosol Sci. Technol., 8(3), 235-244, doi:10.1080/02786828808959186.

Nowak, J. B., J. A. Neuman, K. Kozai, L. G. Huey, D. J. Tanner, J. S. Holloway, T. B. Ryerson, G. J. Frost, S. A. McKeen, and F. C. Fehsenfeld (2007), A chemical ionization mass spectrometry technique for airborne measurements of ammonia, J. Geophys. Res., 112, D10S02, doi:10.1029/2006JD007589.

Ogren, J. A., et al. (1992), Measurements of the size dependence of the concentration of non-volatile material in fog droplets, Tellus, Ser. B, 44, $570-580$

Osthoff, H. D., et al. (2006), Measurement of atmospheric $\mathrm{NO}_{2}$ by pulsed cavity ring-down spectroscopy, J. Geophys. Res., 111, D12305, doi:10.1029/2005JD006942.

Osthoff, H. D., et al. (2008), Significant halogen activation from heterogeneous uptake of reactive nitrogen: Measurements of $\mathrm{ClNO}_{2}$, Nat. Geosci., 1, 324-328, doi:10.1038/ngeo 177 .

Parrish, D. D. (2006), Critical evaluation of US on-road vehicle emission inventories, Atmos. Environ., 40, 2288-2300, doi:10.1016/j.atmosenv. 2005.11.033.

Pierce, R. B., et al. (2009), Impacts of background ozone production on Houston and Dallas, Texas, air quality during the Second Texas Air Quality Study field mission, J. Geophys. Res., 114, D00F09, doi:10.1029/2008JD011337.

Pilewskie, P., J. Pommier, R. Bergstrom, W. Gore, S. Howard, M. Rabbette, B. Schmid, P. V. Hobbs, and S. C. Tsay (2003), Solar spectral radiative forcing during the Southern African Regional Science Initiative, J. Geophys. Res., 108(D13), 8486, doi:10.1029/2002JD002411.

Pour-Biazar, A., et al. (2007), Correcting photolysis rates on the basis of satellite observed clouds, J. Geophys. Res., 112, D10302, doi:10.1029/ 2006JD007422.

Prins, E. M., J. M. Feltz, W. P. Menzel, and D. E. Ward (1998), An overview of GOES-8 diurnal fire and smoke results for SCAR-B and the 1995 fire season in South America, J. Geophys. Res., 103, 31,821-31,836, doi:10.1029/98JD01720.

Quinn, P. K., and T. S. Bates (2005), Regional aerosol properties: Comparisons from ACE 1, ACE 2, Aerosols99, INDOEX, ACE Asia, TARFOX, and NEAQS, J. Geophys. Res., 110, D14202, doi:10.1029/2004JD004755.

Quinn, P. K., T. S. Bates, D. J. Coffman, and D. S. Covert (2008), Influence of particle size and chemistry on the cloud nucleating properties of aerosols, Atmos. Chem. Phys., 8, 1029-1042.

Roberts, G., and A. Nenes (2005), A continuous-flow streamwise thermalgradient CCN chamber for atmospheric measurements, Aerosp. Sci. Technol., 39, 206-221, doi:10.1080/027868290913988.

Roberts, J. M., H. D. Osthoff, S. S. Brown, and A. R. Ravishankara (2008), $\mathrm{N}_{2} \mathrm{O}_{5}$ oxidizes chloride to $\mathrm{Cl}_{2}$ in acidic atmospheric aerosol, Science, 321, 1059, doi:10.1126/science.1158777.

Robinson, R., T. Gardiner, and B. Lipscombe (2008), Measurements of VOC emissions from petrochemical industry sites in the Houston area using Differential Absorption Lidar (DIAL) during summer 2007, final report, 86 pp., Tex. Comm. on Environ. Qual., Austin. (Available at http:// www.tceq.state.tx.us/assets/public/implementation/air/am/contracts/ reports/oth/20080206-dial_test_report.pdf)

Russell, L. M., S. Takahama, S. Liu, L. N. Hawkins, D. S. Covert, P. K. Quinn, and T. S. Bates (2009), Oxygenated fraction and mass of organic aerosol from direct emission and atmospheric processing measured on the R/V Ronald Brown during TexAQS/GoMACCS 2006, J. Geophys. Res., 114, D00F05, doi:10.1029/2008JD011275.

Ryerson, T. B., et al. (1998), Emissions lifetimes and ozone formation in power plant plumes, J. Geophys. Res., 103, 22,569-22,583, doi:10.1029/ 98JD01620.

Ryerson, T. B., L. G. Huey, K. Knapp, J. A. Neuman, D. D. Parrish, D. T. Sueper, and F. C. Fehsenfeld (1999), Design and initial characterization 
of an inlet for gas-phase $\mathrm{NO}_{\mathrm{y}}$ measurements from aircraft, J. Geophys. Res., 104, 5483-5492, doi:10.1029/1998JD100087.

Ryerson, T. B., E. J. Williams, and F. C. Fehsenfeld (2000), An efficient photolysis system for fast-response $\mathrm{NO}_{2}$ measurements, J. Geophys. Res., 105, 26,447-26,461, doi:10.1029/2000JD900389.

Ryerson, T. B., et al. (2003), Effect of petrochemical industrial emissions of reactive alkenes and $\mathrm{NO}_{\mathrm{x}}$ on tropospheric ozone formation in Houston, Texas, J. Geophys. Res., 108(D8), 4249, doi:10.1029/2002JD003070.

Sabine, C. L., R. Wanninkhof, R. M. Key, C. Goyet, and F. J. Millero (2000), Seasonal $\mathrm{CO}_{2}$ fluxes in the tropical and subtropical Indian Ocean, Mar. Chem., 72, 33-53, doi:10.1016/S0304-4203(00)00064-5.

Schauffler, S. M., E. L. Atlas, D. R. Blake, F. Flocke, R. A. Lueb, J. M. Lee-Taylor, V. Stroud, and W. Travnicek (1999), Distributions of brominated organic compounds in the troposphere and lower stratosphere, J. Geophys. Res., 104, 21,513-21,535, doi:10.1029/1999JD900197.

Schmidt, K. S., G. Feingold, P. Pilewskie, H. Jiang, O. Coddington, and M. Wendisch (2009), Irradiance in polluted cumulus fields: Measured and modeled cloud aerosol effects, Geophys. Res. Lett., 36, L07804, doi:10.1029/2008GL036848.

Schwarz, J. P., et al. (2008), Measurement of the mixing state, mass, and optical size of individual black carbon particles in urban and biomass burning emissions, Geophys. Res. Lett., 35, L13810, doi:10.1029/ 2008GL033968.

Shetter, R. E., et al. (2003), Photolysis frequency of $\mathrm{NO}_{2}$ : Measurement and modeling during the International Photolysis Frequency Measurement and Modeling Intercomparison (IPMMI), J. Geophys. Res., 108(D16), 8544, doi:10.1029/2002JD002932.

Shipley, S. T., D. H. Tracy, E. W. Eloranta, J. T. Trauger, J. T. Sroga, F. L. Roesler, and J. A. Weinman (1983), A high spectral resolution lidar to measure optical scattering properties of atmospheric aerosols: Part I. Instrumentation and theory, Appl. Opt., 22, 3716-3724, doi:10.1364/ AO.22.003716.

Sholupov, S., S. Pogarev, V. Ryzhov, N. Mashyanov, and A. Stroganov (2004), Zeeman atomic absorption spectrometer RA-915+ for direct determination of mercury in air and complex matrix samples, Fuel Process. Technol., 85, 473-485, doi:10.1016/j.fuproc.2003.11.003

Sierau, B., D. S. Covert, D. J. Coffman, P. K. Quinn, and T. S. Bates (2006), Aerosol optical properties during the 2004 New England Air Quality Study-Intercontinental Transport and Chemical Transformation: Gulf of Maine surface measurements-Regional and case studies, J. Geophys. Res., 111, D23S37, doi:10.1029/2006JD007568.

Simon, H., Y. Kimura, G. McGaughey, D. T. Allen, J. M. Roberts, S. S. Brown, H. Osthoff, D. Lee, and D. Byun (2009), Modeled effects of nitryl chloride on ozone formation in the Houston area, J. Geophys. Res., 114, D00F03, doi:10.1029/2008JD010732.

Slusher, D. L., L. G. Huey, D. J. Tanner, F. M. Flocke, and J. M. Roberts (2004), A thermal dissociation-chemical ionization mass spectrometry (TD-CIMS) technique for the simultaneous measurement of peroxyacyl nitrates and dinitrogen pentoxide, J. Geophys. Res., 109, D19315, doi:10.1029/2004JD004670

Smith, J., and J. Jarvie (2008), Reconciling reported VOC emissions with ambient measurements, continued, paper presented at Southeast Texas Photochemical Modeling Technical Committee Meeting, Tex. Comm. on Environ. Qual., Austin. (Available at http://www.tceq.state.tx.us/assets/ public/implementation/air/am/committees/pmt set/20080212/20080212 smith-voc_emissions_ambient_measurements.pdf)

Sorooshian, A., F. J. Brechtel, Y. Ma, R. J. Weber, A. Corless, R. C. Flagan, and J. H. Seinfeld (2006), Modeling and characterization of a Particle-into-Liquid Sampler (PILS), Aerosol Sci. Technol., 40(6), 396409, doi:10.1080/02786820600632282.

Stark, H., B. M. Lerner, R. Schmitt, R. Jakoubek, E. J. Williams, T. B. Ryerson, D. T. Sueper, D. D. Parrish, and F. C. Fehsenfeld (2007), Atmospheric in situ measurement of nitrate radical $\left(\mathrm{NO}_{3}\right)$ and other photolysis rates using spectroradiometry and filter radiometry, J. Geophys. Res., 112, D10S04, doi:10.1029/2006JD007578.

Stuart, A. L., A. Aksoy, F. Zhang, and J. W. Nielsen-Gammon (2007), Ensemble-based data assimilation and targeted observation of a chemical tracer in a sea breeze model, Atmos. Environ., 41, 3082-3094, doi:10.1016/j.atmosenv.2006.11.046.

Sullivan, A. P., R. E. Peltier, C. A. Brock, J. A. de Gouw, J. S. Holloway, C. Warneke, A. G. Wollny, and R. J. Weber (2006), Airborne measurements of carbonaceous aerosol soluble in water over northeastern United States: Method development and an investigation into water-soluble organic carbon sources, J. Geophys. Res., 111, D23S46, doi:10.1029/ 2006JD007072.

Thompson, A. M., H. B. Singh, and H. Schlager (2000), Introduction to special section: Subsonic Assessment Ozone and Nitrogen Oxide Experiment (SONEX) and Pollution From Aircraft Emissions in the North
Atlantic Flight Corridor (POLINAT 2), J. Geophys. Res., 105, 35953603, doi:10.1029/2000JD900012.

Thompson, A. M., et al. (2007), Intercontinental Transport Experiment Ozonesonde Network Study (IONS) 2004: 1. Summertime UT/LS (upper troposphere/lower stratosphere) ozone over northeastern North America, J. Geophys. Res., 112, D12S12, doi:10.1029/2006JD007441.

Thompson, A. M., J. E. Yorks, S. K. Miller, J. C. Witte, K. M. Dougherty, G. A. Morris, D. Baumgardner, L. Ladino, and B. Rappenglueck (2008), Tropospheric ozone sources and wave activity over Mexico City and Houston during Milagro/Intercontinental Transport Experiment (INTEX-B) Ozonesonde Network Study, 2006 (IONS-06), Atmos. Chem. Phys., 8, 5113-5125.

Thornberry, T., D. M. Murphy, D. Thomson, J. de Gouw, C. Warneke, T. S. Bates, P. K. Quinn, and D. Coffman (2009), Measurement of aerosol organic compounds using a novel collection/thermal-desorption PTR-ITMS instrument, Aerosol Sci. Technol., 43(5), 486-501, doi:10.1080/02786820902763132.

Tucker, S. C., W. A. Brewer, R. M. Banta, C. J. Senff, S. P. Sandberg, D. C. Law, A. M. Weickmann, and R. M. Hardesty (2009), Doppler lidar estimation of mixing height using turbulence, shear, and aerosol profiles, J. Atmos. Oceanic Technol., 26, 673-688, doi:10.1175/ 2008JTECHA1157.1.

Wang, J., R. C. Flagan, and J. H. Seinfeld (2003), A differential mobility analyzer (DMA) system for submicron aerosol measurements at ambient relative humidity, Aerosol Sci. Technol., 37(1), 46-52, doi:10.1080/ 02786820300891

Wang, S. C., and R. C. Flagan (1990), Scanning electrical mobility spectrometer, Aerosol Sci. Technol., 13(2), 230-240, doi:10.1080/ 02786829008959441

Warneke, C., J. A. De Gouw, E. R. Lovejoy, P. C. Murphy, W. C. Kuster, and R. Fall (2005), Online volatile organic compound measurements using a newly developed proton-transfer ion-trap mass spectrometry instrument during New England Air Quality Study(Intercontinental Transport and Chemical Transformation 2004: Performance, intercomparison, and compound identification, Environ. Sci. Technol., 39, 5390-5397, doi:10.1021/es050602o.

Weber, B. L., et al. (1993), Quality controls for profiler measurements of winds and RASS temperatures, J. Atmos. Oceanic Technol., 10(4), 452-464, doi:10.1175/1520-0426(1993)010<0452:QCFPMO>2.0.CO;2. Weber, R. J., et al. (2001), A particle-in-liquid collector for rapid measurement of aerosol chemical composition, Aerosol Sci. Technol., 35(3), 718-727, doi:10.1080/02786820152546761.

Webster, M., J. Nam, Y. Kimura, H. Jeffries, W. Vizuete, and D. T. Allen (2007), The effect of variability in industrial emissions on ozone formation in Houston, Texas, Atmos. Environ., 41, 9580-9593, doi:10.1016/j.atmosenv.2007.08.052.

Weibring, P., D. Richter, J. G. Walega, and A. Fried (2007), First demonstration of a high performance difference frequency spectrometer on airborne platforms, Opt. Express, 15, 13,476-13,495, doi:10.1364/OE.15.013476.

Wert, B. P., et al. (2003), Signatures of terminal alkene oxidation in airborne formaldehyde measurements during TexAQS 2000, J. Geophys. Res., 108(D3), 4104, doi:10.1029/2002JD002502.

White, A. B., C. J. Senff, A. N. Keane, L. S. Darby, I. V. Djalalova, D. C. Ruffieux, D. E. White, B. J. Williams, and A. H. Goldstein (2006), A wind profiler trajectory tool for air quality transport applications, J. Geophys. Res., 111, D23S23, doi:10.1029/2006JD007475.

Whittlestone, S., and W. Zahorowski (1998), Baseline radon detectors for shipboard use: Development and deployment in the First Aerosol Characterization Experiment (ACE1), J. Geophys. Res., 103, 16,743-16,751, doi:10.1029/98JD00687.

Williams, E. J., et al. (1998), Intercomparison of ground-based $\mathrm{NO}_{\mathrm{y}}$ measurement techniques, J. Geophys. Res., 103, 22,261-22,280, doi:10.1029/ 98JD00074.

Williams, E. J., F. C. Fehsenfeld, B. T. Jobson, W. C. Kuster, P. D. Goldan, J. Stutz, and W. A. McClenny (2006), Comparison of ultraviolet absorbance, chemiluminescence, and DOAS instruments for ambient ozone monitoring, Environ. Sci. Technol., 40, 5755-5762, doi:10.1021/ es0523542.

Wilson, J. C., B. G. Lafleur, H. Hilbert, W. R. Seebaugh, J. Fox, D. W. Gesler, C. A. Brock, B. J. Huebert, and J. Mullen (2004), Function and performance of a low turbulence inlet for sampling super-micron particles from aircraft platforms, Aerosol Sci. Technol., 38(8), 790-802, doi:10.1080/027868290500841

Winker, D. M., W. H. Hunt, and M. J. McGill (2007), Initial performance assessment of CALIOP, Geophys. Res. Lett., 34, L19803, doi:10.1029/ 2007GL030135

Wittig, A. E., and D. T. Allen (2008), Improvement of chemical mass balance model for apportioning-Sources of non-methane hydrocarbons 
using composite aged source profiles, Atmos. Environ., 42, 1319-1337, doi:10.1016/j.atmosenv.2007.10.072.

Wolfe, D. E., et al. (2007), Shipboard multisensor merged wind profiles from the New England Air Quality Study 2004, J. Geophys. Res., 112, D10S15, doi:10.1029/2006JD007344.

Xie, Y., and C. M. Berkowitz (2006), The use of positive matrix factorization with conditional probability functions in air quality studies: An application to hydrocarbon emissions in Houston, Texas, Atmos. Environ., 40, 3070 3091, doi:10.1016/j.atmosenv.2005.12.065.

Xie, Y., and C. M. Berkowitz (2007), The use of conditional probability functions and potential source contribution functions to identify source regions and advection pathways of hydrocarbon emissions in Houston, Texas, Atmos. Environ., 41, 5831-5847, doi:10.1016/j.atmosenv. 2007.03.049

Yarwood, G., T. Stoeckenius, and S. Lau (2004), Top-down evaluation of the Houston emission inventory using inverse modeling, final report, 124 pp., Tex. Environ. Res. Consort., Austin. (Available at http://www. tercairquality.org/AQR/Projects/H006E.2002)

Zamora, R. J., E. G. Dutton, M. Trainer, S. A. McKeen, J. M. Wilczak, and Y.-T. Hou (2005), The accuracy of solar irradiance calculations used in mesoscale numerical weather prediction, Mon. Weather Rev., 133, 783-792, doi:10.1175/MWR2886.1.

Zhang, F., N. Bei, J. W. Nielsen-Gammon, G. Li, R. Zhang, A. Stuart, and A. Aksoy (2007), Impacts of meteorological uncertainties on ozone pollution predictability estimated through meteorological and photochemical ensemble forecasts, J. Geophys. Res., 112, D04304, doi:10.1029/ 2006JD007429.
Zhao, Y., J. N. Howell, and R. M. Hardesty (1993), Transportable lidar for the measurement of ozone concentration and aerosol profiles in the lower troposphere, Proc. SPIE Int. Soc. Opt. Eng., 2112, 10 pp.

Zhao, W., P. Hopke, and T. Karl (2004), Source identification of volatile organic compounds in Houston, Texas, Environ. Sci. Technol., 38, 13381347, doi: $10.1021 / \mathrm{es} 034999 \mathrm{c}$.

D. T. Allen, Center for Energy and Environmental Resources, University of Texas at Austin, Austin, TX 78758, USA.

T. S. Bates, Pacific Marine Environmental Laboratory, National Oceanic and Atmospheric Administration, 7600 Sand Point Way NE, Seattle, WA 98115, USA.

M. Estes, Texas Commission on Environmental Quality, 12100 Park Thirty Five Circle, Austin, TX 78753-1808, USA.

F. C. Fehsenfeld, G. Feingold, R. M. Hardesty, J. F. Meagher, D. D. Parrish, T. B. Ryerson, and E. J. Williams, Chemical Sciences Division, ESRL, National Oceanic and Atmospheric Administration, 325 Broadway, Mail Stop R/CSD7, Boulder, CO 80305, USA. (david.d.parrish@ noaa.gov)

R. Ferrare, NASA Langley Research Center, Hampton, VA 23681, USA. J. W. Nielsen-Gammon, Department of Atmospheric Sciences, Texas A\&M University, College Station, TX 77843-3150, USA.

R. B. Pierce, STAR, NESDIS, NOAA, Madison, WI 53706, USA.

J. H. Seinfeld, Department of Environmental Science and Engineering, California Institute of Technology, Pasadena, CA 91125, USA. 